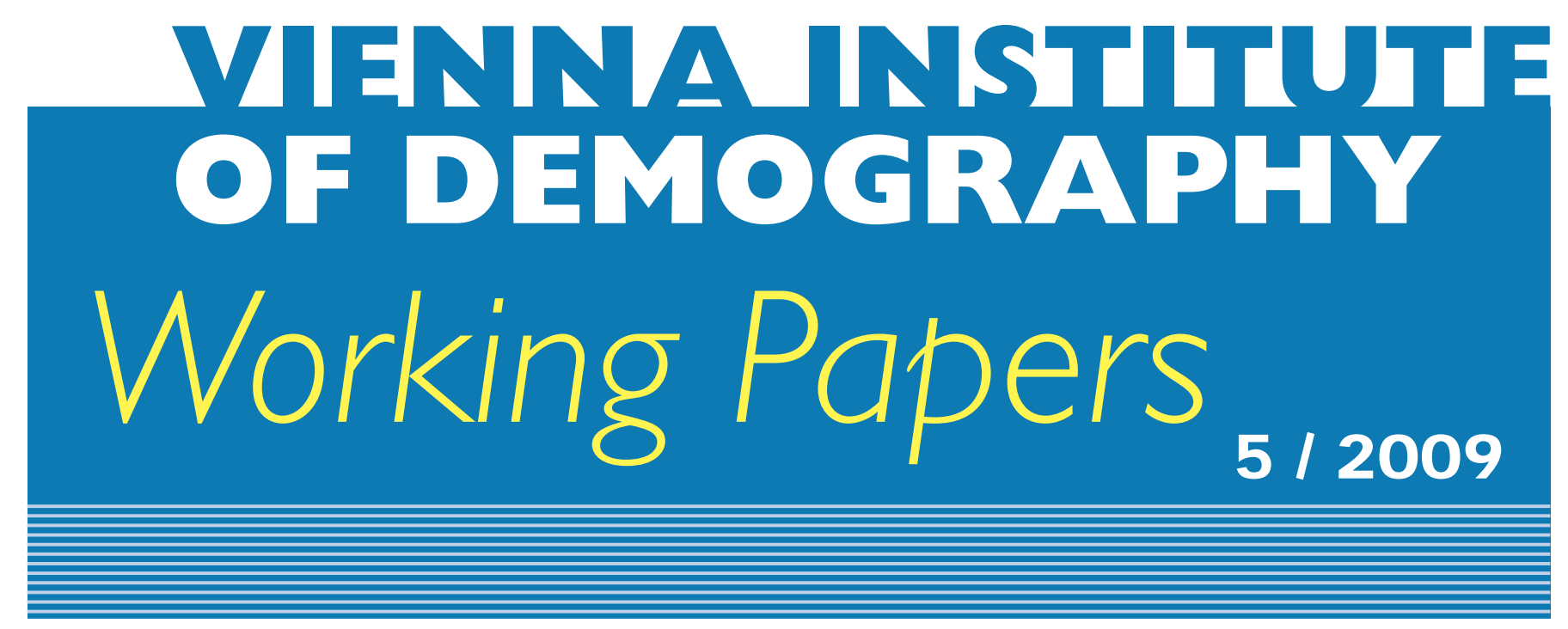

Christian W egner and M arc Luy

\title{
Determinants of General Health Status and Specific Diseases of Elderly Women and Men: A Longitudinal Analysis for Western and Eastern Germany
}

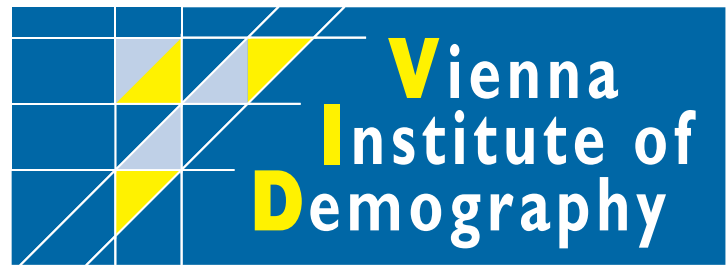

Vienna Institute of Demography Austrian Academy of Sciences

Wohllebengasse 12-14

A-I040 Vienna · Austria

E-Mail:vid@oeaw.ac.at Website: www.oeaw.ac.at/vid

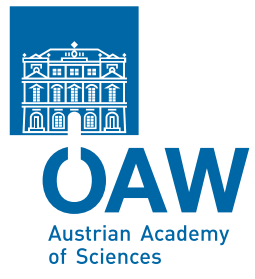




\begin{abstract}
We used the panel data of the German Life Expectancy Survey (LES) for analysing the impact of specific life conditions on the gender-specific health outcome of respondents aged $60+$ at follow-up over a period of 13 years (for western Germany) and 7 years (for eastern Germany) respectively. For western Germany we extended the analysis by additional information about life course experiences with unemployment, smoking behaviour, reproduction history and migration background. We analysed self-rated general health as well as the self-reported absence and prevalence of specific diseases which are directly related to the main causes of death and disabilities. Moreover, we analysed death and attrition as competing risks at follow-up in order to control for selection effects to the health outcome. The analysis was separated by sex to account for gender-specific life conditions. The results confirm existing knowledge regarding socioeconomic differences and offer insights into the influence of health lifestyles, in particular sports activity and smoking history. Further, associations were found between the earlier presence of diseases and the health condition at follow-up. Gender differences in health outcomes are partly explained by the higher mortality of males and the higher number of non-respondents among females. The study extends the knowledge about risk factors for health in Germany by a longitudinal approach and emphasises the importance of earlier life stage intervention to reduce disease-specific risk factors.
\end{abstract}

\title{
Keywords
}

Health, subjective health, disease, health transition, western and eastern Germany, longitudinal analysis, gender, ageing, life course

\section{Authors}

Christian Wegner is Research Scientist at the Vienna Institute of Demography of the Austrian Academy of Sciences. Email: Christian.Wegner@,oeaw.ac.at

Marc Luy is Senior Scientist at the Vienna Institute of Demography of the Austrian Academy of Sciences. Email: Mark.Luy@,oeaw.ac.at 


\title{
Determinants of General Health Status and Specific Diseases of Elderly Women and Men: A Longitudinal Analysis for Western and Eastern Germany
}

\author{
Christian Wegner and Marc Luy
}

\section{Introduction}

In general, the health status at old age has an important individual and social relevance. The vulnerability is increasing by physiological and morphological changes in the organism and central nervous system during the ageing process. The indicators of physiological health are based on prevalence of disabilities and causes of death. In Germany the main causes of death are circulatory diseases, neoplasms, diseases of respiratory system and diseases of digestive system (Statistisches Bundesamt 2007a; Nolte, Shkolinikov \& McKee 2000). The statistics of hospital diagnoses present circulatory diseases and neoplasm as the main reasons for referrals to nursing homes at age 60 and older. Furthermore, $77 \%$ of all circulatory diseases were first diagnosed for person aged $60+, 64 \%$ of neoplasm, $44 \%$ of all respiratory diseases and $51 \%$ of digestive diseases (Statistisches Bundesamt 2007b).

Increasing physiological and psychological impairments with age does not mean that ageing is equivalent with illness, diseases or dependency. In fact, earlier studies could not explore that a type or the pathogenesis of diseases is only caused by the ageing process (Steinhagen-Thiessen \& Borchelt 1996). Brody and Schneider (1986) distinguished between age-dependent and age-related diseases. Age-dependent diseases are involved in the ageing process and cause the exponentially increasing mortality risk with advanced age, for instance heart and cerebrovascular diseases. Age-related diseases like musculoskeletal diseases are relating temporally with age and have no causal effect on the increasing individual mortality risk.

The presence or absence of diseases is strongly associated with individual health but did not fulfil the multidimensional concept of health. Health is characterised by dynamic and multi-factorial influences on the physical, psychological and social functioning of an individual. On the one hand, an objective health status includes the set of diagnosed physiological and psychological diseases of an individual. By contrast, the subjective health status is indicated by impairments in daily activities, functional limitation and a decline in life quality as consequence of specific diseases. Moreover, the subjective health status is a better predictor of a person's future medical constitution than the objective one (Maddox \& Douglass 1973) and a validated predictor of mortality (Mossey \& Shapiro 1982).

The analysis of health determinants also plays an important role for avoiding health hazards and for improvement in longevity. Recent research extracted a variety of determinants 
differentiated by hereditary (Vaupel et al. 1998; Christensen, Johnson \& Vaupel 2006; Guimarães 2007), socioeconomic (Wilkinson 2001) and behavioural (Blaxter 1990) factors. The socioeconomic status is a powerful indicator of individual health, physical disabilities and mortality (Wadsworth 1997; Marmot \& Wilkinson 2006). A concave social gradient could be determined for mortality, coronary heart diseases (Kaplan \& Keil 1993) and respiratory diseases (Calverley \& Pride 1995). Experience in earlier life with stress (Leserman et al. 1998; Bartley 1991) and unemployment (Bartley 1994) also increases the probability of a poor health status. However, the direction of causation is indeterminate. On the one hand, poverty is a risk factor for increasing morbidity and mortality (causation), whereas on the other, illness and the presence of diseases and disabilities reduce the chances of reaching a higher socioeconomic status (selection).

So far, the impact of social inequality on health has mainly been examined for the working-age population (Feinstein 1993). Results of the relation between health and social inequality in older age have been somewhat less consistent than findings for working age individuals. Some studies (House, Kessler \& Herzog 1990; House et al. 1994) present a weaker effect of income, education, occupation and race for people aged 65 or older. However, other scholars described significant relations between socioeconomic status and health outcome for younger as well as for older age groups (Berkman \& Gurland 1998; Melzer et al. 2000). The current research distinguishes four hypotheses regarding the changes in the structure and the specific impacts on social inequality in older age (Mayer \& Wagner 1996): (i) the age dependency hypothesis, (ii) the continuity hypothesis, (iii) the destructuring hypothesis and (iv) the accumulation hypothesis. The age dependency hypothesis assumes that the social status of older people decreases with the decline of physiological and psychological ability. Above all, care dependency causes severe declines in self-determination, social and cultural activity and social status (Mollenkopf \& Walker 2007). Additionally, the economic status can also decrease by the supplemental costs for illness and care. The continuity hypothesis, however, implies that social status of earlier life will be stable in older age (Knesebeck \& Schäfer 2006). Thereby, social ageing would be a differential process with different progresses for different social stratums or certain socioeconomic characteristics. In contrast, the destructuring hypothesis assumes that differences in social status disappear after leaving the working age. Therefore, the process of social ageing is the same for all persons independent of socioeconomic background. Finally, the accumulation hypothesis (Blane 2006) assumes an interaction between age and socioeconomic differentiations. Earlier social circumstances influence adult socioeconomic positions by assuring savings, investments and pension in old age. Cross-sectional studies on the socioeconomic situation of younger elderly persons in Germany found support for the continuity as well as for the accumulation hypothesis (Knesebeck et al. 2003; Mayer \& Wagner 1996).

Apart from socioeconomic differences in health, there is a substantial literature on health behaviours and lifestyle characteristics. Smoking, alcohol consumption, nutrition, physical activity, living arrangement and social networks are behaviours and lifestyle factors which are known to be related to health. However, the causal associations are complex and interrelated to an individual's socioeconomic status (Blaxter 1990). Smoking has probably the most 
negative effect on health and survival (USDHHS 2004; Haustein 2001). Smokers reduce their life by about ten years and do not improve at all, or to a lesser extent, from overall benefits in longevity (Doll et al. 2004). The risk of cardiovascular disease, chronic respiratory diseases, lung and other forms of cancer is significantly higher for smokers than for non-smokers. Recent studies showed significant socioeconomic differences in smoking behaviour. This gradient results on only from the fact that lower educated persons smoke more frequently at middle and early old age but also from the fact that higher educated individuals have higher rates of quitting smoking (Cavelaars et al. 2000). Further, smokers are likely associated with low income, low occupational prestige and higher risk of unemployment (Helmert, Borgers \& Bamman 2001, Gruer et al. 2009). The effect of alcohol intake on health is more complex compared to definite impact of smoking. Heavy alcohol consumption is associated with higher risk of liver diseases, neoplasm in the digestive tract, cognitive changes, ischemic stroke and behavioural problems (Beresford \& Katsoyannis 1995; Corrao et al. 1998; Mukamal et al. 2005; Sacco et al. 1999; Thun et al. 1997). In contrast, moderate intake lowers the risk of cardiovascular diseases and mortality (Abramson et al. 2001; Thun et al. 1997). Likewise, Mäkelä, Valkonen and Martelin (1997) have shown that relative socioeconomic differentials are present to a larger extent in alcohol-related mortality than in overall mortality. Beside this, health and mortality preventive behaviour is also associated with physical activity. Physical fitness appears to be a graded, independent long-term predictor of mortality from cardiovascular diseases (Sandvik et al. 1993). A high level of fitness was even shown to lower mortality from all causes of death (USDHHS 1996). Moderate physical activity has a protective effect beyond age 80 (Lindsted, Tonstad \& Kuzma 1991) since it helps to maintain normal blood-pressure and avoid obesity (Paffenbarger et al. 1993).

Healthy behaviour and its protective effect on health and mortality are closely related to an individual's social ties (Berkman \& Glass 2000; Gorman \& Sivaganesan 2007). The marriage status provides social support (Lillard \& Panis 1996), comprising emotional support (family integration, stress reduction) as well as instrumental support (caregiving in times of illness). These protective effects are known to be associated with reduced health impairments for both sexes (Grundy \& Holt 2000; Waldron, Hughes \& Brooks 1996; Wyke \& Ford 1992). However, significant associations between marital and survival status were only reported for males (Waldron, Hughes \& Brooks 1996; Scafato et al. 2008). Apart from the strong effect of living arrangements, a few studies also found a linkage of mortality to fertility with a J-shaped mortality risk from nulliparous to higher-parity females (Green, Beral \& Moser 1988; Lund, Arnesen \& Borgan 1990; Doblhammer 2000; Grundy \& Tomassini 2005). Furthermore, childbearing in early life is also associated with higher mortality, whereas birth after age 40 is related to lower risk of dying (Doblhammer 2000; Grundy \& Tomassini 2005). Men's survivorship, however, seems to be independent from number of biological children (Friedlander 1996).

In general, the specific health determinants are interrelated to each other and similarly age-dynamic as health itself. The life course approach in epidemiological research is focused on critical periods and the accumulation of adverse environmental conditions and unhealthy behaviours for explaining variations in health (Graham 2002; Kuh et al. 2003; Kuh \& Ben- 
Shlomo 2004). The epidemiological approach integrates different concepts of health and treats ageing as a sequence of life events and experiences with their consequences for an individual's health status.

This working paper focuses on the relevance of social, socioeconomic and behavioural factors on health status and mortality in a longitudinal setting and in a life-course perspective. First, we identify those factors which determine the health status of people aged $60+$ in Germany. Based on this, our second aim is to find factors which determine transitions from good general health status, or from the absence of specific diseases, to a bad general health status or the presence of specific diseases. Therefore, the most important age-dependent and age-related diseases will be analysed separately as well as combined to multimorbidity. Although many determinants of health and mortality have been identified, there are still several open questions regarding the role of these determinants in specific population settings. The specific characteristic of our study is the analysis of the role of these determinants regarding gender differences in the context of the population of western and eastern European societies. We investigate the impact of 17 potential health determinants on seven health outcomes as well as mortality over a time of 13 years (West Germany) and seven years (East Germany), respectively. The eastern and western Germany populations provide the unique possibility to study the effects of eastern and western European backgrounds in one population. The two pre-reunification German regions were characterised by a demographic composition and demographic conditions that were almost identical until 1945, but after that saw 45 years under different political and socio-economic structures, resulting in demographic developments that were entirely characterised by either the eastern or the western European systems (Gjonça, Brockmann \& Maier 2000; Vaupel, Carey \& Christensen 2003). 


\section{Data and Methods}

\subsection{Data Sample}

For our analysis we used longitudinal data from the German Life Expectancy Survey (LES) of the German Federal Institute of Population Research (BiB). The LES is a two-wave panel study on the relation between lifestyle, health and mortality for western and eastern Germany, restricted to persons with German citizenship (Gärtner 2001). The data contains individual information about demographics, economic and social status, social networks, health behaviours, life attitudes and a variety of health indicators for the cohorts born between 1914 and 1952. The first wave belongs to the Heart Circulation Prevention Study (HCP), including representative population samples for western Germany of the years 1984 to 1986. After unification the HCP was extended to eastern Germany with the first HCP survey being conducted there in the years 1991 and 1992. The LES comprises second interviews with the samples of the first HCP surveys of 1984-1986 and 1991-1992, respectively, which were conducted by the $\mathrm{BiB}$ in 1998 for both parts of Germany. Consequently, the follow-up time span of the LES differs between the eastern and western German sub-samples, being approximately seven years for the former and 13 years for the latter.

We restricted our analysis to respondents aged 60 or older at the time of the second interview. Thus, the analysed sub-sample included respondents of the second wave and those who got lost by death or attrition but hypothetically would have been 60 or older. Missing cases of covariates were suspended after testing their independent distribution. The original West sample includes 4,865 individuals. Of these, 3,944 (81\%) reported the full information for analysis, 2,091 males and 1,853 females (see Table 1). From those females, 871 participated in the second wave, 184 died between the two survey waves and 798 got lost due to other reasons. The corresponding numbers of the western German males are 951 participants in the second wave, 435 deaths and 705 cases of attrition. The original East sample includes 831 respondents of which 805 (97\%) provided complete information without any missing cases. Of these, 444 persons were females and 361 were males. Of those, 229 females and 189 males participated in the second wave, whereas 44 females and 53 males died and 171 females and 119 males dropped out between the two survey waves.

Table 1: Descriptive characteristics of the LES follow-up survey at 1998

\begin{tabular}{cl|rrr|c}
\hline & & participated & \multicolumn{1}{c|}{ died } & \multicolumn{1}{c}{ loss } & total \\
\hline Western & Females & $871(47 \%)$ & $184(10 \%)$ & $798(43 \%)$ & 1853 \\
Germany & Males & $951(45 \%)$ & $435(21 \%)$ & $705(34 \%)$ & 2091 \\
Eastern & Females & $229(52 \%)$ & $44(10 \%)$ & $171(38 \%)$ & 444 \\
Germany & Males & $189(52 \%)$ & $53(15 \%)$ & $119(33 \%)$ & 361 \\
\hline
\end{tabular}




\subsection{Health Measures}

The change in health was analysed for several specific health conditions. All information is self-reported by the respondents. The information on health and specific diseases therefore reflects the subjective health status of the respondents rather than their objective health. However, subjective health is closely related to objective health and known to be a good predictor for mortality (Mossey \& Shapiro 1982). Furthermore, recent research indicates that the subjective health status is a better predictor of an individual's physical constitution than vice versa (Maddox \& Douglass 1973). The general health status was defined on the basis of the question "How do you rate your health in general?" indicating a person's perceived physical and psychological health condition as consequence of the presence or absence of impairments in daily activities (Knesebeck 1998). Apart from the general health status, we analysed nine specific diseases which are known to be closely related to death or disability. Thus, the analysed diseases can be expected to have a significant impact on an individuals' quality of life. Specifically, in terms of the ICD-9 nomenclature the analysed diseases are 'heart diseases', 'cerebral vascular diseases', 'hypertension', 'other diseases of the circulatory system', 'endocrine, nutritional and metabolic diseases', 'diseases of the musculoskeletal system and connective tissue', 'diseases of the digestive system', 'diseases of the genitourinary system' and 'diseases of the respiratory system'. Finally, we addressed the state of multimorbidity by summarising the number of diseases out of those four of the analysed diseases which are closely related to the risk of dying (see below).

The number of self-reported diseases differs between the samples for western and eastern Germany and between the survey waves. In the first wave, the West sample contains information about the presence (or absence) of 37 specific diseases, whereas the East sample includes only 35 specific diseases. The difference results from the lack of information about diseases of the respiratory system in eastern Germany. The second wave of the LES includes 40 self-reported diseases. For defining the specific disease groups we selected 28 diseases of the western and 25 diseases of eastern German sample. Appendix A summarises these diseases and shows how the nine groups of specific diseases were classified in detail.

All analysed health variables were dichotomised into 'good' and 'bad' in the case of the general health status and into 'presence' and 'absence' for each specific disease and multimorbidity. In the original questionnaire, the general health status was measured by a five item scale ('very good', 'good', 'fair', 'bad' and 'poor'). We defined those with 'very good' and 'good' general health into the category 'good' and the rest into the category 'bad'. The original questions for the specific diseases contained four categories to characterise the disease status during the last 12 months preceding the surveys: (1) suffers of disease at the moment, (2) had disease earlier, but not anymore, (3) doesn't know whether disease is still present, and (4) never had that disease. 
We merged the answer categories (1) and (3) into the new category 'present' and the categories (2) and (4) into 'absent'. ${ }^{1}$ The status 'absent' was valid when all diseases within a summarised disease group were either never experienced or one or more diseases were experienced only in the past, respectively. If at least one specific disease of a disease group was reported as being present during the 12 months preceding the survey the disease was defined as 'present'.

Multimorbidity was defined as the co-occurrence of diseases, in contrast to the concept of co-morbidity which specifies additional diseases beside the specific disease under study (Akker, Buntix \& Knottnerus 1996). The co-occurrence of diseases is associated with impairments in physical functioning, the requirement of complex therapy and care as well as increased needs for social, medical and health care (Akker et al. 1998). We analysed multimorbidity as cumulative occurrence of heart diseases, cerebral vascular diseases, diseases of the respiratory system and diseases of the digestive system. The scale was dichotomised to 'present' and 'absent' in the logic that was already described for the specific disease groups. Thus, the state 'absent' (multimorbidity) includes all persons who experienced one or none of the four mentioned diseases at the time of the survey. Individuals who experienced two, three or all of these four diseases were defined to the group 'present' (multimorbidity). Unfortunately, multimorbidity could only be analysed for western Germany due to the small size of the eastern German LES sample.

\subsection{Measures of individual life conditions}

In our analysis of health status we included a total of 17 control variables, i.e. sex, age, education level, occupational status, net household income, living arrangement, social contacts, consumption of high-proof alcohol, weekly sports activity, general consideration of health, general satisfaction with life, body mass index, 'type A' behaviour, experience of unemployment, smoking status and history, number of children and migration background. All of these variables were defined by their characteristics at the moment of the first survey and are expected to reflect properly the life condition, the socioeconomic status, the social arrangement, the health lifestyle and earlier life events of the respondents as most important determinants of status and changes of their health condition. Again, the questions are not identical in the eastern and western German samples, and they also differ between the two survey waves. We restricted the analysis to control variables which were available for both parts of Germany and for both waves. The consideration of information from both waves allowed to minimise the number of missing cases in the control variables since missing information in the first survey could be substituted when the corresponding information was

\footnotetext{
${ }^{1}$ Defining answer category (3) as 'present' disease was based on the idea that the word "still" in the question implies that the respondent must have experienced the disease at some time in the past and he or she does just not know whether that disease is still present. Nevertheless, the case numbers of this category are so low that the definition of the disease being 'present' or 'absent' does not have any significant influence on the results of the analysis.
} 
given in the second survey. For eastern Germany (and in some cases for western German females as well) it was necessary to aggregate categories as they were used for western German males because of the small sample size(s). Note that due to this different categorisation the results for eastern and western Germany (and in some cases also for females and males) are not directly comparable. However, for both samples it is possible to investigate if a specific life condition has any impact on health or not.

Age was classified into four groups up to age 50, 51 to 55, 56 to 60 and older than 60 for western Germany and into three groups up to age 60,61 to 70 and older than 70 for eastern Germany, always referring to the age at baseline. ${ }^{2}$ Socioeconomic status was measured by three variables education level, occupational status and net household income. Education level was measured by means of the international standard classification of education ISCED-97 (OECD 1999). For western Germany, the corresponding categories are 'primary', 'secondary' and 'high education level'. For the eastern German sample the education level was dichotomised into two groups 'up to secondary education' and 'higher education'. The current or last occupational status was classified into blue collar, white collar, civil servants and selfemployed for western German males. The occupational status of western German females was categorised into blue collar, white collar and civil servants, self-employed and housewives. The latter were defined on basis of the current employment status as those females who were never employed or who resigned from employment before the age of 50 . In the eastern sample the occupational status had to be reduced to the dichotomous status 'blue collar' and 'others' for both sexes. Net household income was originally classified in more than ten income groups. For both parts of Germany we categorised the net household income by the corresponding tertiles into low, middle and high.

Living arrangement and number of friends were used as indicators for an individual's social background. For the western German sample, living arrangement was operationalised as a combination of marital status and the number of persons living in the same household. The category 'married' comprises all married persons, regardless whether they are living together with the spouse or living alone. Divorced, widowed or never married respondents were classified into the two groups 'living together with at least one other person' and 'living alone'. For eastern Germany, the living arrangement had to be dichotomised into the groups 'living together with at least one other person' and 'living alone', thus, the information about the marital status was excluded here. The number of friends was derived from the question "To how many persons outside your household are you so close that you don't want to miss their friendship?". Respondents who stated three or more such persons were grouped into the category 'many social contacts'. All persons with less than three close persons were categorised into 'few social contacts'. In this case, the classification was done identical for eastern and western Germany.

\footnotetext{
${ }^{2}$ In this way the age groups cover comparable birth cohorts in the eastern and in the western German LES sample.
} 
Lifestyle was characterised by a set of four variables for both eastern and western German sample, namely the consumption of high-proof alcohol, the weekly sports activity, health consciousness and the general satisfaction with life. All of these variables were dichotomised into one group with specific characteristics and the rest category. Regarding alcohol consumption the respondents were separated into people who never drunk high-proof alcohol and all others. Respondents who exercised sports regularly at least once per week were classified as 'active in sports'. Health consciousness measurement was based on the question "How much do you take care of your own health?", with the possible answers 'very much, 'much', 'medium', 'almost not' and 'not at all'. We defined health-conscious people as those who answered with 'much' or 'very much' to this question. The general satisfaction with life was characterised by the two categories 'satisfied' and 'unsatisfied' (based on a similar fivescale question and combing 'much' and 'very much' satisfied to the group of people being satisfied with their life in general). In the western sample we included additional information on the body mass index and the so-called 'type A behaviour'. Based on the definition of Jenkins (1976, p. 1034) type A describes "a style of behaviour characterised by some or all of the following: intense striving for achievement; competitiveness; easily provoked impatience; time urgency; abruptness of gesture and speech; overcommitment to vocation or profession; and excesses of drive and hostility" and is known to be closely related to heart diseases. We measured and classified the type A on a three-item scale (low/middle/strong) as suggested by Luy and Di Giulio (2005).

Apart from these characteristics of respondents at the moment of the first interview (or in the 12 preceding months, respectively) we were able to reconstruct some former life-course events using information provided by the LES. These life-course events are the experience of unemployment, smoking history (in combination with the current smoking status), fertility history and migration background. The reconstruction of the corresponding life-course variables was based either on information about their timing and duration or on information about the past experiences of the events. The experience of unemployment could be traced for the samples of both parts of Germany. The current smoking status could be separated into 'never smoker', 'ex-smoker' and 'current smoker' for the western German sample and for eastern German males. For eastern German females the smoking status could only be separated into 'never smokers' on the one side and 'current and ex-smokers' on the other side. For the western German sample we could further use information about the age at starting and the age at quitting to smoke. Using these data we calculated the number of smoking years (measured as a continuous variable) and combined this information with the current smoking status. Our measurement of fertility history comprises a combination of the number of biological children and the age at birth. Therefore, the age at birth was dichotomised into 'below mean age at birth' and 'above mean age at birth' for both LES samples. Regarding parity we could separate into 'no child', 'one child', 'two children' and 'three and more children' for western Germany, whereas in eastern Germany only the parities 0, 1 and 2+ could be analysed. The last included covariate is the migration background of the respondents. For western Germany we characterised the migration background of those who ever migrated by the number of years living in the current residence. Further information about reasons or 
number of migrations was not available. For eastern Germany we could only separate between persons who ever migrated and all others.

\subsection{Method}

The analysis was done separately for eastern and western Germany as well as for males and females. Thus, our analysis led to four independent sets of results. In a first step we analysed the impact of the considered covariates on the various health and disease statuses at the moment of first interviews (baseline) by means of standard logistic regression. In a second step we analysed the transitions of general health, specific diseases and multimorbidity after follow-up by applying multinomial logistic regression models (Hosmer \& Lemeshow 2000) separately for each health variable. Results of the multinomial logistic regression models are to be interpreted as results of standard logistic regression models. In all models persons without changes during the follow-up comprise the reference group.

Figure 1: Set of analysed health transition

General Health Status

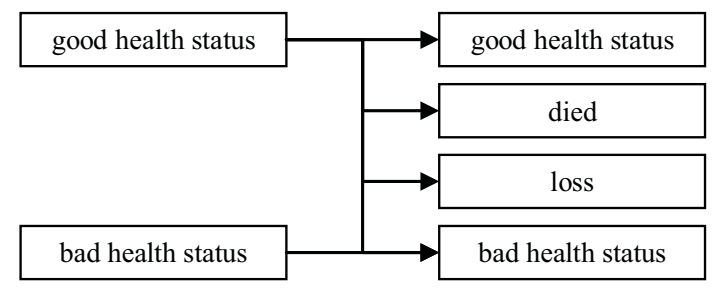

Disease Status

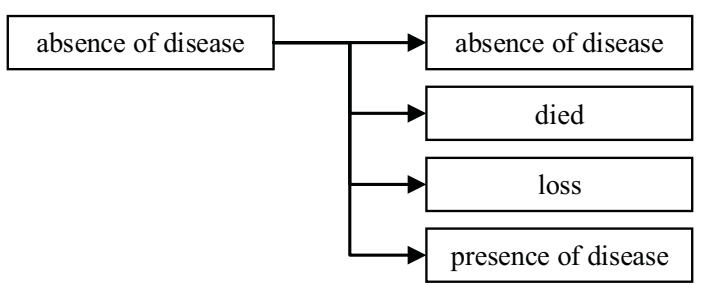

Status of Multimorbidity

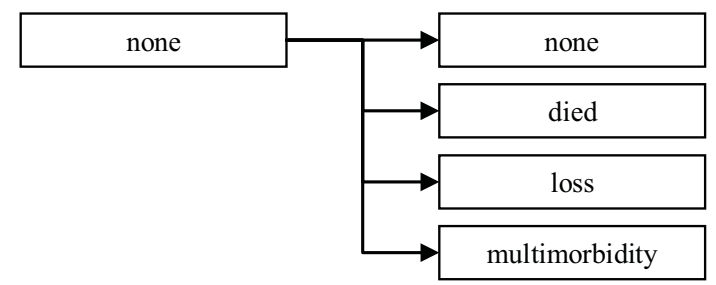

Figure 1 presents the corresponding variety of health transitions for each health variable in our analysis. Each individual was identified to belong to one specific transition. Depending on the case numbers of the LES sub-samples the number of analysed transitions differs between them. Regarding general health the full set of possible transitions from good or bad health status at baseline was possible only for western Germany. For eastern Germany only the transition from bad health at baseline could be analysed. The number of people suffering from the specific diseases at baseline was generally to low to allow a detailed analysis of transitions during the observation time. Thus, transitions of disease statuses could only be 
analysed for the state of disease absence at baseline. Likewise, the transitions of multimorbidity were only analysed for respondents without co-occurrence of the considered diseases at baseline. Table 2 gives an overview of the applied transition models for the four analysed LES sub-samples.

Table 2: Analysed health transitions for females and males in western and eastern German LES sample

\begin{tabular}{l|cc|cc}
\hline & \multicolumn{2}{|c|}{ West } & \multicolumn{3}{c}{ East } \\
& Female & Male & Female & Male \\
\hline Baseline & & & & \\
General health status & $\mathrm{x}$ & $\mathrm{x}$ & $\mathrm{x}$ & $\mathrm{x}$ \\
Diseases & $\mathrm{x}$ & $\mathrm{x}$ & $\mathrm{x}$ & $\mathrm{x}$ \\
Multimorbidity & $\mathrm{x}$ & $\mathrm{x}$ & & \\
\hline Follow-up & $\mathrm{x}$ & $\mathrm{x}$ & & \\
Transition good bad health status & $\mathrm{x}$ & $\mathrm{x}$ & $\mathrm{x}$ & $\mathrm{x}$ \\
Transition bad good health status & $\mathrm{x}$ & $\mathrm{x}$ & $\mathrm{x}$ & $\mathrm{x}$ \\
Transition absence presence of disease & $\mathrm{x}$ & $\mathrm{x}$ & & \\
Transition none $\rightarrow$ multimorbidity & \multicolumn{5}{|c}{}
\end{tabular}

\section{Results}

\subsection{Health, diseases and multimorbidity}

Table 3 presents the gender-specific proportion of transitions from baseline general health status to status after 13-years follow-up for western Germany. At baseline, females had a lower percentage $(26 \%)$ of general good health status as compared to males $(36 \%)$. Thirty per cent of females with a good health status at baseline remained in good health until follow-up (assuming no deterioration and later improvement of health between the two surveys). On the other hand, 22 per cent experienced transition to bad health and seven per cent died during the 13 years. From females with bad general health status at baseline 37 per cent kept the same health status whereas eigth per cent moved to good health and 11 per cent died. The highest proportion was caused by panel attrition for both baseline health statuses. From males with good health at baseline, 28 per cent remained in good health and 23 per cent experienced health deterioration. One-third of males with bad health at baseline kept their health status and nine per cent experienced a change to good health. The proportion of deceased males was more than twice the corresponding number among females. However, the percentage of panel attrition was smaller among males then among females. The gender-specific status of analysed diseases at baseline is presented in Table 4 for western Germany. The proportion of heart diseases $(22 \%)$, cerebrovascular diseases $(10 \%)$ and diseases of musculoskeletal system and connective tissue $(55 \%)$ did not significantly differ between females and males. Males had a 
significantly higher percentage of diseases of the respiratory system whereas females had a higher proportion of diseases of the digestive system.

Table 3: Transition of general health status by gender, western Germany (in \%)

\begin{tabular}{rc|rrrrr}
\hline \multicolumn{2}{c|}{ West } & \multicolumn{5}{c}{ Status at 1998 } \\
\multicolumn{2}{c|}{ Status at } & \multicolumn{6}{c}{ 1984/86 } & good & bad & \multicolumn{1}{c}{ died } & \multicolumn{1}{l}{ loss } & \multicolumn{1}{c}{ n } \\
\hline \multirow{2}{*}{ Female } & good & 30.0 & 22.3 & 6.6 & 41.1 & $\mathbf{4 8 4}(26 \%)$ \\
& bad & 7.8 & 37.3 & 11.1 & 43.8 & $\mathbf{1 3 6 9}(74 \%)$ \\
\hline \multirow{2}{*}{ Male } & good & 27.9 & 22.5 & 14.7 & 34.9 & $\mathbf{7 3 0}(36 \%)$ \\
& bad & 8.7 & 32.6 & 24.8 & 34.0 & $\mathbf{1 3 2 5}(64 \%)$ \\
\hline
\end{tabular}

Table 4: Proportion of disease status at baseline by gender, western Germany (in \%) ${ }^{\mathrm{a}}$

\begin{tabular}{l|cc|cc}
\hline \multicolumn{1}{c|}{ Diseases } & \multicolumn{2}{|c|}{$\begin{array}{c}\text { Female } \\
\text { absence }\end{array}$} & $\begin{array}{c}\text { presence } \\
\text { pres3) }\end{array}$ & \multicolumn{2}{c}{$\begin{array}{c}\text { Male }(\mathbf{n}=\mathbf{2 0 5 5}) \\
\text { absence }\end{array}$} & presence \\
\hline Heart Diseases & 78 & 22 & 78 & 22 \\
Cerebralvascular Diseases & 90 & 10 & 91 & 9 \\
Diseases of Respiratory System & 91 & $\mathbf{9}$ & 84 & $\mathbf{1 6}$ \\
Diseases of Digestive System & 51 & $\mathbf{4 9}$ & 61 & $\mathbf{3 9}$ \\
$\begin{array}{l}\text { Diseases of Musculoskeletal System and } \\
\text { Connective Tissue }\end{array}$ & 45 & 55 & 43 & 57 \\
\hline
\end{tabular}

${ }^{a}$ Bold indicates significant difference between female and male at $\mathrm{p}<0.05$

The gender-specific proportion of transition from the absence of diseases to the same or a different health status at follow-up for western Germany is presented in Table 5. The percentages of developing heart diseases, cerebrovascular diseases, diseases of the respiratory system and diseases of the digestive system at follow-up were significantly higher among men than among women. The prevalence of diseases of the musculoskeletal system and connective tissue was equal for both sexes. However, males had a higher proportion of deaths -on average 10 percentage points- for all analysed diseases. In contrast, the percentage of attrition during the follow-up period was significantly higher among females than among males. Transition to multimorbidity (Figure 2) was significantly higher among males (12\%) than among females $(10 \%)$. Again, the male proportion of deaths during the follow-up period was higher by 10 per cent, whereas panel attrition was lower among males (35\%) as compared to females (44\%). 
Table 5: Health transition by absence of specific diseases by gender, western Germany (in \%) ${ }^{\mathrm{a}}$

\begin{tabular}{|c|c|c|c|c|c|c|}
\hline \multirow{2}{*}{ Absence of Disease at $\mathbf{1 9 8 4 / 8 6}$} & \multirow{2}{*}{ Sex } & \multicolumn{4}{|c|}{ Status at 1998} & \multirow[b]{2}{*}{$\mathbf{n}$} \\
\hline & & absence & presence & died & loss & \\
\hline \multirow{2}{*}{ Heart Diseases } & $\mathbf{F}$ & 41.4 & 7.7 & 8.0 & 42.9 & 1454 \\
\hline & $\mathbf{M}$ & 38.1 & 9.2 & 17.7 & 35.1 & 1605 \\
\hline \multirow{2}{*}{ Cerebralvascular Diseases } & $\mathbf{F}$ & 42.9 & 4.3 & 9.4 & 43.4 & 1666 \\
\hline & $\mathbf{M}$ & 40.1 & 5.2 & 19.8 & 34.9 & 1876 \\
\hline \multirow{2}{*}{ Diseases of Respiratory System } & $\mathbf{F}$ & 44.2 & 3.0 & 9.3 & 43.6 & 1678 \\
\hline & M & 41.8 & 4.8 & 18.8 & 34.7 & 1722 \\
\hline \multirow{2}{*}{ Diseases of Digestive System } & $\mathbf{F}$ & 37.7 & 7.1 & 10.0 & 45.2 & 952 \\
\hline & $\mathbf{M}$ & 39.7 & 5.7 & 20.0 & 34.6 & 1258 \\
\hline Diseases of Musculoskeletal & $\mathbf{F}$ & 29.7 & 13.9 & 10.2 & 46.2 & 826 \\
\hline System and Connective Tissue & $\mathbf{M}$ & 30.4 & 14.9 & 21.6 & 33.0 & 884 \\
\hline
\end{tabular}

${ }^{a}$ Bold indicates significant difference between female and male at $\mathrm{p}<0.05$

Figure 2: Health transition by absence of multimorbidity by gender, western Germany (in \%)

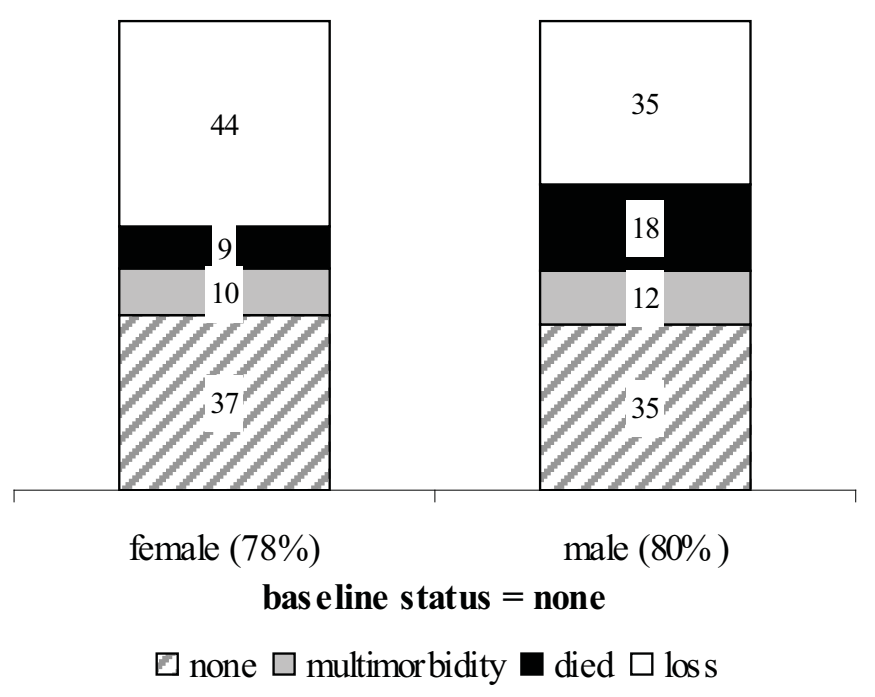

The proportions of changes in general health status between first survey and follow-up for eastern Germany are presented in Table 6. From females with good health status at baseline 29 per cent kept their good health, 28 per cent changed to bad health status and five per cent died during the follow-up period. On the other hand, 41 per cent of females remained in bad health status, nine per cent experienced improvement to good general health and 11 per 
cent died until the follow-up. Among males, 30 per cent with good baseline health status remained in this condition whereas 26 per cent experienced deterioration in general health and nine per cent died during the follow-up period. From males with bad health at baseline, 42 per cent remained in the bad health status, nine per cent moved to good health and 17 per cent died between the two surveys. The proportion of panel attrition was lower among males than among females.

Table 6: Transition of general health status by gender, eastern Germany (\%)

\begin{tabular}{rc|rrrrr}
\hline \multicolumn{2}{c|}{ East } & \multicolumn{5}{c}{ Status at 1998 } \\
\multicolumn{2}{c}{ Status at 1991/92 } & good & bad & died & \multicolumn{1}{l}{ loss } & \multicolumn{1}{c}{ n } \\
\hline \multirow{2}{*}{ Female } & good & 28.7 & 27.7 & 5.3 & 38.3 & $\mathbf{9 4}(21 \%)$ \\
& bad & 8.9 & 41.4 & 11.1 & 38.6 & $\mathbf{3 5 0}(79 \%)$ \\
\hline \multirow{2}{*}{ Male } & good & 30.3 & 26.3 & 9.1 & 34.3 & $\mathbf{9 9}(27 \%)$ \\
& bad & 9.2 & 41.6 & 16.8 & 32.4 & $\mathbf{2 6 2 ( 7 3 \% )}$ \\
\hline
\end{tabular}

The disease status at baseline for eastern Germany is presented in Table 7. Presence of diseases of circulatory system and diseases of digestive system was higher in females than in males. Half of both sexes' respondents experienced diseases of musculoskeletal system and connective tissue.

Table 7: Proportion of disease status at baseline by gender, eastern Germany (in \%) ${ }^{\mathrm{a}}$

\begin{tabular}{l|cc|cc}
\hline \multicolumn{1}{c|}{ Diseases } & \multicolumn{2}{c|}{ Female $(\mathbf{n}=\mathbf{4 4 4})$} & \multicolumn{2}{c}{ Male (n= 361) } \\
& absence & presence & absence & presence \\
\hline Diseases of Circulatory System & 58 & $\mathbf{4 2}$ & 64 & $\mathbf{3 6}$ \\
$\begin{array}{l}\text { Diseases of Digestive System } \\
\begin{array}{l}\text { Diseases of Musculoskeletal System and } \\
\text { Connective Tissue }\end{array}\end{array}$ & 48 & $\mathbf{5 2}$ & 63 & $\mathbf{3 7}$ \\
\hline
\end{tabular}

${ }^{a}$ Bold indicates significant difference between female and male at $\mathrm{p}<0.05$ 
Table 8 gives the proportions of transition from the absence of specific diseases to the new status at follow-up. A significant difference in onset of disease by gender was only measurable for diseases of circulatory system. ${ }^{3}$ The proportion was higher among females $(12 \%)$ than among males (9\%). The percentage of deceased individuals was significantly higher among males with absence of diseases of the circulatory system and diseases of the digestive system at baseline. In case of diseases of the musculoskeletal system and connective tissue the proportion of deceased was three percentage points higher among males, though without statistical significance. A statistically significant higher proportion of attrition was again valid for females as compared to males in all analysed diseases.

Table 8: Health transition by specific diseases by gender, eastern Germany (in \%) ${ }^{\mathrm{a}}$

\begin{tabular}{|c|c|c|c|c|c|c|}
\hline \multirow{2}{*}{ Absence of Disease at 1991/92 } & \multirow{2}{*}{ Sex } & \multicolumn{4}{|c|}{ Status at 1998} & \multirow[b]{2}{*}{$\mathbf{n}$} \\
\hline & & absence & presence & died & loss & \\
\hline \multirow{2}{*}{ Diseases of Circulatory System } & $\mathbf{F}$ & 45.2 & 12.4 & 5.4 & 37.1 & 259 \\
\hline & $\mathbf{M}$ & 46.1 & 9.1 & 12.6 & 32.2 & 230 \\
\hline \multirow{2}{*}{ Diseases of Digestive System } & $\mathbf{F}$ & 43.2 & 7.5 & 8.5 & 40.8 & 213 \\
\hline & $\mathbf{M}$ & 48.5 & 5.7 & 15.3 & 30.6 & 229 \\
\hline Diseases of Musculoskeletal & $\mathbf{F}$ & 35.7 & 14.5 & 9.7 & 40.1 & 207 \\
\hline System and Connective Tissue & $\mathbf{M}$ & 39.7 & 14.9 & 12.6 & 32.8 & 174 \\
\hline
\end{tabular}

${ }^{a}$ Bold indicates significant difference between female and male at $\mathrm{p}<0.05$

\subsection{Health and disease determinants at baseline}

Table 9 shows for women in western Germany the results from fitting logistic regression models to the data on general health status, the whole set of analysed diseases and multimorbidity at baseline. The modelled outcome was bad general health and presence of specific diseases, respectively. Regarding general health, the odds of being in bad health showed a concave increase with age (except age group 51-55 years). Lower education as well as lowest net household income groups increased the odds of bad health, although the strength of these associations did not reach the five per cent significance level. However, sports inactivity, a low health consciousness and dissatisfaction with life increased the odds of poor or fair health with high statistical significance. Furthermore, all groups of diseases except the presence of hypertension were significantly associated with bad health status. The odds of presence of heart diseases additionally increased with age. Blue-collar occupation and the middle net household income group were positively associated with heart diseases. The lifestyle indicators show that low health consciousness was related to lower odds of bad health whereas dissatisfaction with life increased the odds. Former smoking was also related to high odds of bad general health. Each additional year of smoking increased the odds of reporting

\footnotetext{
${ }^{3}$ Diseases of the circulatory system are a mixture of heart diseases and cerebrovascular diseases, classified together for eastern Germany so as to obtain a sufficient number of cases for analysis, see Appendix 1.
} 
bad general health by two per cent. The presence of other diseases was also associated with higher odds of heart diseases, except diseases of the digestive system and diseases of the musculoskeletal system and connective tissue. The age effect disappeared for the rest of analysed diseases. Furthermore, primary education was related to higher odds of digestive diseases but the significance did not reach the five per cent level. In contrast to heart diseases, the odds of having digestive diseases were lower for blue-collar occupation. Moreover, strong type A behaviour and high-proof alcohol consumption significantly increased the odds of having diseases of the digestive system. The effect of alcohol consumption was also valid for diseases of the musculoskeletal system and connective tissue. Sports inactivity was associated with higher odds of having respiratory diseases but reduced the odds of suffering from diseases of the musculoskeletal system and connective tissue. Dissatisfaction with life was positively related to the occurrence of cerebrovascular diseases and diseases of the respiratory system. Furthermore, earlier experiences with unemployment increased the odds of having cerebrovascular diseases at the moment of the first survey. The effect of former smoking was valid for diseases of the respiratory system and diseases of the musculoskeletal system and connective tissue. Current smoking was associated with higher odds of suffering from respiratory diseases. The last column in Table 9 presents the results for the analysis of multimorbidity. Females aged 60 or older had 70 per cent higher odds to suffer from multimorbidity than the reference category. Further, a higher likelihood of multimorbidity was associated with housewife status, sports inactivity, dissatisfaction with life and earlier experience with unemployment. In contrast, a low health consciousness was associated with lower odds of multimorbidity. A bad general health as well as the presence of all other considered diseases (besides those being part of the definition of multimorbidity, see Section 2.2) increased the odds of having multimorbidity. 
Table 9: Results of logistic regression for general health status, diseases and multimorbidity at baseline, females, western Germany

\begin{tabular}{|c|c|c|c|c|c|c|c|c|}
\hline \multicolumn{2}{|c|}{ Covariates } & $\begin{array}{c}\text { General } \\
\text { Health }\end{array}$ & \multirow[t]{2}{*}{$\begin{array}{c}\text { Heart } \\
\text { Diseases }\end{array}$} & \multirow[t]{2}{*}{\begin{tabular}{|c|}
$\begin{array}{c}\text { Cerebralvasc. } \\
\text { Diseases }\end{array}$ \\
\end{tabular}} & \multirow[t]{2}{*}{$\begin{array}{c}\text { Respiratory } \\
\text { Diseases }\end{array}$} & \multirow[t]{2}{*}{$\begin{array}{l}\text { Digestive } \\
\text { Diseases }\end{array}$} & \multirow[t]{2}{*}{ MSCT $^{\mathbf{a}}$} & \multirow[t]{2}{*}{$\begin{array}{c}\text { Multi- } \\
\text { morbidity }\end{array}$} \\
\hline Age & $<50 \mathrm{yrs}$ & & & & & & & \\
\hline & $51-55 \mathrm{yrs}$ & $1.60 * *$ & $1.61 *$ & 1.05 & 1.11 & 1.14 & 1.17 & 1.23 \\
\hline & $56-60 \mathrm{yrs}$ & 1.25 & $1.75^{* *}$ & 0.81 & 1.20 & 0.82 & $1.34 \dagger$ & 1.23 \\
\hline & $>60 \mathrm{yrs}$ & $1.49 *$ & $2.45^{* * *}$ & 1.43 & 1.19 & 0.84 & 1.26 & $1.71 * *$ \\
\hline \multirow{2}{*}{ BMI } & ideal & & & & & & & \\
\hline & overweight & 1.22 & 0.97 & 1.03 & 0.86 & $0.79 *$ & 1.16 & 0.89 \\
\hline Education & high & & & & & & & \\
\hline & primary & $1.44 \dagger$ & 1.26 & 0.67 & 0.96 & $1.38 \dagger$ & 0.87 & 1.12 \\
\hline & secondary & $1.31 \dagger$ & 1.06 & 1.07 & 1.07 & 1.17 & 0.84 & 1.01 \\
\hline Current/Last Occupationa & I white collar & & & & & & & \\
\hline Status & blue collar & 1.03 & $1.71 * *$ & 1.17 & 1.46 & $0.71 *$ & 1.06 & $1.40 \dagger$ \\
\hline & self-employed & 1.13 & 1.18 & 1.02 & 0.92 & 0.75 & 1.20 & 1.06 \\
\hline & housewife & 0.98 & 1.20 & 1.20 & $1.60 \dagger$ & 1.04 & 1.03 & $1.52 *$ \\
\hline Household Net Income & high & & & & & & & \\
\hline & low & $1.36 \dagger$ & 1.04 & 1.03 & 0.94 & 1.09 & 0.94 & 0.98 \\
\hline & middle & 1.10 & $1.46 *$ & 1.06 & 1.12 & 0.90 & 1.02 & 1.21 \\
\hline Life Arrangement & married & & & & & & & \\
\hline & living with other & 0.97 & $1.42 \dagger$ & 1.08 & 0.93 & 1.10 & $0.60 * *$ & 1.06 \\
\hline & living alone & 0.75 & 1.40 & 0.82 & 1.17 & 0.95 & 1.00 & 1.10 \\
\hline Number of Friends & many & & & & & & & \\
\hline & none/few & 1.12 & 0.94 & 1.29 & 1.28 & 1.04 & 1.20 & 1.17 \\
\hline Typ A (Jenkins) & weak & & & & & & & \\
\hline & strong & 1.08 & 1.03 & 0.94 & 0.84 & $1.32 * *$ & 1.02 & 1.03 \\
\hline Alcohol Consumption & no & & & & & & & \\
\hline & yes & 0.78 & 0.96 & 0.72 & 0.92 & $1.43 *$ & $1.39 *$ & 1.32 \\
\hline Sport Activity & yes & & & & & & & \\
\hline & no & $1.70^{* * *}$ & 1.12 & 1.20 & $1.61 *$ & 0.92 & $0.67^{* * *}$ & $1.36 *$ \\
\hline Health Consciousness & strong & & & & & & & \\
\hline & weak & $1.60 * * *$ & $0.74 *$ & $0.65 *$ & 1.02 & 0.93 & 0.93 & $0.57^{* * *}$ \\
\hline Life Satisfaction & satisfied & & & & & & & \\
\hline & unsatisfied & $2.81 * * *$ & $1.42 *$ & $2.01 * * *$ & $1.48 \dagger$ & 1.23 & 1.08 & $2.17 * * *$ \\
\hline Ever unemployed & no & & & & & & & \\
\hline & yes & 1.23 & 1.27 & $1.68 * *$ & 0.81 & 1.18 & 1.11 & $1.53 * *$ \\
\hline Reproductive History & none & & & & & & & \\
\hline & $1 \mid$ before age 27 & 1.30 & $0.64 \dagger$ & 1.59 & 1.21 & 1.13 & 0.95 & 0.94 \\
\hline & $1 \mid$ after age 27 & 1.06 & 0.87 & 1.40 & 0.95 & 0.88 & 1.36 & 0.91 \\
\hline & $2 \mid$ before age 25 & 1.17 & 0.84 & 1.16 & 1.01 & 1.05 & 1.00 & 0.87 \\
\hline & $2 \mid$ after age 25 & 0.83 & 1.03 & 1.06 & 0.83 & 0.94 & 0.96 & $0.68 \dagger$ \\
\hline & $3+\mid$ before age 24 & 0.99 & 0.89 & 1.19 & 1.13 & 0.92 & 0.91 & 0.96 \\
\hline & $3+\mid$ after age 24 & 1.08 & 0.94 & 0.98 & 0.83 & 0.97 & 0.74 & 0.89 \\
\hline Smoking Status & Smoking Years (Former) & 0.99 & $1.02 *$ & 1.00 & $1.02 \dagger$ & 1.01 & $1.01 \dagger$ & $1.01 \dagger$ \\
\hline & Smoking Years (Current) & 1.00 & 0.99 & $0.98 * *$ & $1.02 * *$ & 1.01 & 1.00 & 1.00 \\
\hline Migration History & never migrated & & & & & & & \\
\hline & since $10 \mathrm{yrs}$ & $0.60 *$ & 1.47 & 0.91 & 1.41 & 1.24 & 0.83 & 1.22 \\
\hline & since $20 \mathrm{yrs}$ & 1.03 & 1.33 & 0.83 & 0.99 & 1.24 & 1.09 & 1.06 \\
\hline & since $30 \mathrm{yrs}$ & 0.84 & 1.11 & 0.85 & 0.76 & 0.98 & 0.97 & 0.95 \\
\hline & more than $30 \mathrm{yrs}$ & 0.92 & 1.31 & 0.84 & 0.81 & 1.22 & 0.92 & 1.00 \\
\hline General Health Status & good & & & & & & & \\
\hline & bad & - & $3.06^{* * *}$ & $1.73 \dagger$ & $1.61 \dagger$ & $1.61 * * *$ & $2.22 * * *$ & $3.17^{* * *}$ \\
\hline Heart Diseases & absence & & & & & & & \\
\hline & presence & $3.17 * * *$ & - & $2.88 * * *$ & $1.52 *$ & 1.19 & 1.14 & - \\
\hline Cerebralvascular Diseases & absence & & & & & & & \\
\hline & presence & $1.83 *$ & $2.81^{* * *}$ & - & 0.98 & $1.84^{* * *}$ & 1.30 & - \\
\hline Hypertension & absence & & & & & & & \\
\hline & presence & 1.24 & $2.39^{* * *}$ & 1.07 & 0.98 & 1.07 & 0.93 & $1.58 * *$ \\
\hline Other Diseases of & absence & & & & & & & \\
\hline Circulatory System & presence & $1.36 *$ & $2.56 * * *$ & $1.90 * *$ & 1.08 & $1.62 * * *$ & $1.50 * * *$ & $2.28 * * *$ \\
\hline Diseases of Respiratory & absence & & & & & & & \\
\hline System & presence & $1.78 *$ & $1.45 \dagger$ & 0.94 & - & 1.26 & $1.75 * *$ & - \\
\hline Endocrine,Nutritional \& & absence & & & & & & & \\
\hline Metabolic Diseases & presence & $1.34 *$ & $1.47^{* *}$ & 1.26 & $1.74 * *$ & $1.29 *$ & $1.43^{* *}$ & $1.76 * * *$ \\
\hline Diseases of Digestive & absence & & & & & & & \\
\hline System & presence & $1.59 * * *$ & 1.21 & $1.88^{* * *}$ & 1.27 & - & $1.70^{* * *}$ & - \\
\hline Diseases of Musculoskeleta & I absence & & & & & & & \\
\hline System and Connective & presence & $2.20 * * *$ & 1.18 & $1.38 \dagger$ & $1.77 * *$ & $1.71 * * *$ & - & $1.56 * *$ \\
\hline Diseases of the & absence & & & & & & & \\
\hline Genitourinary System & presence & $2.07 * * *$ & $1.43^{*}$ & 1.27 & $1.85 * *$ & $1.89^{* * *}$ & $1.36 *$ & $2.01 * * *$ \\
\hline & $\mathbf{N}$ & 1853 & 1853 & 1853 & 1853 & 1853 & 1853 & 1853 \\
\hline & df & 41 & 41 & 41 & 41 & 41 & 41 & 38 \\
\hline & $-2 \operatorname{lnL}$ & -871 & -760 & -497 & -515 & -1160 & -1146 & -804.2 \\
\hline & Pseudo- $\mathrm{R}^{2}$ & 0.181 & 0.286 & 0.181 & 0.111 & 0.096 & 0.100 & 0.180 \\
\hline
\end{tabular}

$\dagger \mathrm{p}<0.1, * \mathrm{p}<0.05, * * \mathrm{p}<0.01, * * * \mathrm{p}<0.001$

${ }^{a}$ Diseases of Muscoloskeletal System and Connective Tissue 
The results for the logistic regression for general health status, diseases and multimorbidity at baseline for men in western Germany are given in Table 10. The factors associated with increased odds of having fair or poor health status did not differ from those of females. The odds of having fair or poor health at the time of the first survey increased with age. The odds were also higher among males with low educational level and low net household income. Low health consciousness and dissatisfaction with life were associated with higher odds of reporting bad general health. Except for the other diseases of the circulatory system, all diseases increased the odds of being in bad general health. Further associations could be observed for fertility and migration background, though without being statistically significant at the five per cent level. Earlier fatherhood was associated with higher odds except for three or more children. Respondents who had lived less than 20 years in the same place showed a lower risk of having fair or poor health. An age effect existed also for the presence of heart diseases and cerebrovascular diseases. In contrast, the odds of presence of diseases of the digestive system declined with age. The impact of education disappeared for the analysed diseases whereas income effects were only associated with higher odds of the occurrence of diseases of the respiratory system. Strong type A behaviour lowered the odds of having cerebrovascular diseases but increased the risk of suffering from diseases of the digestive system and diseases of the musculoskeletal system and connective tissue. Fatherhood was associated with lower odds of having diseases of the respiratory system, regardless of the number of children or the age at childbearing. Smoking, however, led to high odds of the presence of heart diseases and diseases of the respiratory system. Furthermore, almost all other considered diseases were strongly associated with higher odds of the presence of the analysed diseases. Higher odds of multimorbidity were found for males aged 60 or older, males who are unsatisfied with life and males who had had experience with tobacco consumption. In contrast, lower odds of suffering from multimorbidity were found for overweight males and males with one child regardless of the age at childbearing. The strong interrelation between diseases was also apparent for multimorbidity. Therefore, bad general health and the presence of all other diseases were strongly associated with a higher likelihood of reporting multimorbidity. 
Table 10: Results of logistic regression for general health status, diseases and multimorbidity at baseline, males, western Germany

\begin{tabular}{|c|c|c|c|c|c|c|c|c|}
\hline \multicolumn{2}{|c|}{ Covariates } & \multirow[t]{2}{*}{$\begin{array}{c}\text { General } \\
\text { Health }\end{array}$} & \multirow[t]{2}{*}{$\begin{array}{c}\text { Heart } \\
\text { Diseases }\end{array}$} & \multirow[t]{2}{*}{\begin{tabular}{|c} 
Cerebralvase. \\
Diseases
\end{tabular}} & \multirow[t]{2}{*}{$\begin{array}{c}\text { Respiratory } \\
\text { Diseases }\end{array}$} & \multirow[t]{2}{*}{$\begin{array}{c}\text { Digestive } \\
\text { Diseases }\end{array}$} & \multirow[t]{2}{*}{ MSCT $^{\mathbf{a}}$} & \multirow[t]{2}{*}{$\begin{array}{c}\text { Multi- } \\
\text { morbidity }\end{array}$} \\
\hline Age & $<50 \mathrm{yrs}$ & & & & & & & \\
\hline & $51-55 \mathrm{yrs}$ & $1.67 * * *$ & 0.94 & $2.20 *$ & 0.83 & $0.79 \dagger$ & 1.05 & 0.77 \\
\hline & $56-60 \mathrm{yrs}$ & $1.91 * * *$ & $1.53 *$ & $2.23 *$ & 0.73 & $0.77 \dagger$ & 1.26 & 1.14 \\
\hline & $>60 \mathrm{yrs}$ & $1.60 * *$ & $1.79 * *$ & $4.45^{* * *}$ & 1.09 & $0.71 *$ & 1.07 & $1.77 * *$ \\
\hline \multirow[t]{2}{*}{ BMI } & ideal & & & & & & & \\
\hline & overweight & 0.96 & 0.85 & 1.19 & 0.94 & $0.75 * *$ & 0.92 & $0.73 *$ \\
\hline Education & high & & & & & & & \\
\hline & primary & $1.80 *$ & 0.92 & 1.29 & 0.73 & 1.17 & 0.86 & 1.05 \\
\hline & secondary & $1.36 *$ & 1.25 & 0.91 & 0.95 & 1.10 & 0.92 & 1.16 \\
\hline Current/Last Occupationa & white collar & & & & & & & \\
\hline Status & blue collar & $1.46 * *$ & 1.05 & 1.04 & 0.93 & 0.83 & 1.09 & 1.09 \\
\hline & civil servants & 1.20 & 0.80 & $1.84 *$ & 0.81 & 1.01 & 1.01 & 1.17 \\
\hline & self-employed & 1.03 & 1.15 & 0.74 & 0.90 & 0.80 & 1.05 & 0.95 \\
\hline Household Net Income & high & & & & & & & \\
\hline & low & $1.73 * * *$ & 0.93 & 0.85 & $1.81 * * *$ & $0.75 \dagger$ & 1.07 & 0.92 \\
\hline & middle & $1.55 * * *$ & 0.94 & 0.83 & 0.89 & 0.88 & $1.26 \dagger$ & 0.81 \\
\hline Life Arrangement & married & & & & & & & \\
\hline & living with other & 1.14 & 0.76 & $2.17 \dagger$ & 0.75 & 0.72 & 0.80 & 1.05 \\
\hline & living alone & 0.99 & 0.83 & 1.19 & 0.73 & $1.55 \dagger$ & $0.42 * * *$ & 0.69 \\
\hline Number of Friends & many & & & & & & & \\
\hline & none/few & 1.20 & 0.94 & 1.11 & 0.99 & 0.86 & 0.89 & 0.99 \\
\hline Typ A (Jenkins) & weak & & & & & & & \\
\hline & strong & 0.84 & 1.24 & $0.56 * *$ & 1.13 & $1.26 *$ & $1.26 *$ & 1.24 \\
\hline Alcohol Consumption & no & & & & & & & \\
\hline & yes & 0.85 & 1.19 & 1.00 & $1.25 \dagger$ & 0.88 & 1.04 & 1.13 \\
\hline Sport Activity & yes & & & & & & & \\
\hline & no & $1.23 \dagger$ & 1.16 & 0.90 & 1.19 & 1.19 & 0.86 & 1.23 \\
\hline Health Consciousness & strong & & & & & & & \\
\hline & weak & $1.65 * * *$ & $0.74 *$ & 0.76 & 0.92 & 0.91 & 1.01 & 0.82 \\
\hline Life Satisfaction & satisfied & & & & & & & \\
\hline & unsatisfied & $3.03 * * *$ & 0.95 & 1.35 & $1.32 \dagger$ & $1.30 \dagger$ & 1.09 & $1.48 *$ \\
\hline Ever unemployed & no & & & & & & & \\
\hline & yes & 1.00 & 1.13 & 1.00 & 1.16 & 1.11 & $1.39 * *$ & $1.27 \dagger$ \\
\hline Reproductive History & none & & & & & & & \\
\hline & $1 \mid$ before age 30 & $1.48 \dagger$ & 0.64 & 0.95 & $0.41 * *$ & 0.95 & 1.07 & $0.35 * * *$ \\
\hline & $1 \mid$ after age 30 & 1.09 & 0.66 & 1.10 & $0.64 \dagger$ & 1.05 & 1.15 & $0.61 \dagger$ \\
\hline & 2 before age 28 & $1.48 \dagger$ & 0.99 & 0.99 & $0.63 *$ & 1.09 & 1.05 & 0.80 \\
\hline & $2 \mid$ after age 28 & 1.09 & 0.88 & 1.38 & $0.56 * *$ & 1.18 & 1.01 & 0.85 \\
\hline & $3+\mid$ before age 26 & 1.08 & 0.75 & 1.51 & $0.56 *$ & 1.16 & 1.15 & 0.81 \\
\hline & $3+\mid$ after age 26 & 0.86 & 0.96 & 1.00 & $0.56 * *$ & 1.33 & 0.88 & 0.77 \\
\hline Smoking Status & Smoking Years (Former) & 1.00 & $1.02 * *$ & 0.99 & 1.00 & $1.01 \dagger$ & 1.00 & $1.01 *$ \\
\hline & Smoking Years (Current) & 1.00 & 1.00 & 0.99 & $1.02 * * *$ & 1.00 & 1.00 & $1.01 * *$ \\
\hline Migration History & never migrated & & & & & & & \\
\hline & since $10 \mathrm{yrs}$ & $0.69 \dagger$ & 1.14 & 1.42 & 0.90 & 1.31 & 1.04 & 1.39 \\
\hline & since $20 \mathrm{yrs}$ & $0.76 \dagger$ & 1.00 & 1.17 & $1.41 \dagger$ & 1.10 & $1.30 \dagger$ & 1.13 \\
\hline & since $30 \mathrm{yrs}$ & 0.96 & 0.79 & 1.05 & 0.94 & 1.03 & 0.96 & 0.87 \\
\hline & more than $30 \mathrm{yrs}$ & 0.88 & $0.73 \dagger$ & 1.01 & 1.03 & 1.23 & 0.98 & 0.85 \\
\hline General Health Status & good & & & & & & & \\
\hline & bad & - & $2.38^{* * *}$ & $2.03 * *$ & $1.67 * *$ & $2.01 * * *$ & $1.51 * * *$ & $3.03 * * *$ \\
\hline Heart Diseases & absence & & & & & & & \\
\hline & presence & $2.32 * * *$ & - & $3.81 * * *$ & $1.31 \dagger$ & 1.12 & $1.54 * *$ & - \\
\hline Cerebralvascular Diseases & absence & & & & & & & \\
\hline & presence & $1.86 *$ & $3.66^{* * *}$ & - & $1.59 *$ & $1.78 * *$ & 1.10 & - \\
\hline Hypertension & absence & & & & & & & \\
\hline & presence & $1.54 * *$ & $2.08 * * *$ & $1.85 * *$ & 0.94 & 1.02 & $1.22 \dagger$ & $1.85^{* * *}$ \\
\hline Other Diseases of & absence & & & & & & & \\
\hline Circulatory System & presence & 1.17 & $1.71^{* * *}$ & $2.19^{* * *}$ & $1.28 \dagger$ & $1.65^{* * *}$ & $1.77 * * *$ & $2.32 * * *$ \\
\hline Diseases of Respiratory & absence & & & & & & & \\
\hline System & presence & $1.78^{* * *}$ & $1.34 \dagger$ & $1.58 *$ & - & $1.37 *$ & 1.18 & - \\
\hline Endocrine,Nutritional \& & absence & & & & & & & \\
\hline Metabolic Diseases & presence & $1.62 * * *$ & $1.75^{* * *}$ & $1.44 \dagger$ & $1.37 *$ & $1.44 * * *$ & $1.73^{* * *}$ & $2.44 * * *$ \\
\hline Diseases of Digestive & absence & & & & & & & \\
\hline System & presence & $2.06 * * *$ & 1.12 & $1.74 * *$ & $1.34 *$ & - & $1.50 * * *$ & - \\
\hline Diseases of Musculoskeleta & I absence & & & & & & & \\
\hline System and Connective & presence & $1.53 * * *$ & $1.51 * *$ & 1.16 & 1.16 & $1.50^{* * *}$ & - & $1.44 *$ \\
\hline Diseases of the & absence & & & & & & & \\
\hline Genitourinary System & presence & $1.32 \dagger$ & 1.23 & $1.55^{*}$ & $1.36 *$ & $1.66 * * *$ & $1.53 * * *$ & $1.76 * * *$ \\
\hline & $\mathbf{N}$ & 2055 & 2055 & 2055 & 2055 & 2055 & 2055 & 2055 \\
\hline & df & 41 & 41 & 41 & 41 & 41 & 41 & 38 \\
\hline & $-2 \ln \mathrm{L}$ & -1085 & -852 & -443 & -814 & -1220 & -1252 & -813.9 \\
\hline & Pseudo-R ${ }^{2}$ & 0.188 & 0.363 & 0.271 & 0.106 & 0.111 & 0.109 & 0.2158 \\
\hline
\end{tabular}

$\dagger \mathrm{p}<0.1,{ }^{*} \mathrm{p}<0.05,{ }^{* *} \mathrm{p}<0.01, * * * \mathrm{p}<0.001$

${ }^{\mathrm{a}}$ Diseases of Muscoloskeletal System and Connective Tissue 
The results of the logistic regression model for eastern German females are given in Table 11. Low net household income, low health consciousness, and the presence of diseases of the circulatory system as well as diseases of the musculoskeletal system and connective tissue were associated with higher odds of experiencing bad general health at baseline. On the other hand, lower odds of being in bad general health at the time of the first survey were associated with high-proof alcohol consumption. Increasing odds by age were found for diseases of the circulatory system and diseases of the musculoskeletal system and connective tissue. The latter was additionally related to high-proof alcohol consumption. Low health consciousness and the presence of circulatory diseases as well as other occupations than bluecollar occupation and diseases of the musculoskeletal system and connective tissue reduced the odds for the presence of diseases at the time of the first survey. The interrelation between the presence of diseases at baseline could also be found for eastern German females. Bad general health, the presence of hypertension and that of diseases of the digestive system were associated with higher odds of suffering diseases of the circulatory system. An increased likelihood of having diseases of the digestive system was related to the presence of other diseases of the circulatory system, diseases of the musculoskeletal system and connective tissue and the presence of diseases of the genitourinary system. Further, the presence of diseases of the musculoskeletal system and connective tissue was related to being in fair or poor health as well as to the presence of other diseases of the circulatory system, diseases of the digestive system and diseases of the genitourinary system.

Table 12 presents the corresponding results for eastern German males. Sports inactivity, dissatisfaction with life as well as the presence of diseases of the circulatory system and hypertension were related to higher odds of reporting bad general health at the time of the first survey. However, later fatherhood of two or more children reduced the likelihood of being in bad general health. An age effect on the occurrence of the considered diseases could only be found for diseases of the digestive system with the odds being lower for the males in the highest age group than for males below age 60. Low health consciousness and earlier experience with unemployment reduced the odds of the having diseases of the circulatory system. In contrast, higher odds were found for males with a migration background. The same was found for diseases of the digestive system regarding earlier fatherhood of one child and for diseases of the musculoskeletal system and connective tissue regarding dissatisfaction with life. The influence of other diseases also increased the odds of suffering from specific diseases. Diseases of the circulatory system (heart and cerebral vascular diseases) were associated with general bad health, the presence of hypertension and the presence of other diseases of the circulatory system (hypotension, thrombosis and circulatory disturbance periphery). Higher odds of the presence of diseases of the digestive system were associated with the presence of other diseases of the circulatory system, diseases of the musculoskeletal system and connective tissue and diseases of the genitourinary system. However, only the presence of diseases of the digestive system was associated with a higher likelihood of having diseases of the musculoskeletal system and connective tissue. 
Table 11: Results of logistic regression for general health status and diseases at baseline, females, eastern Germany

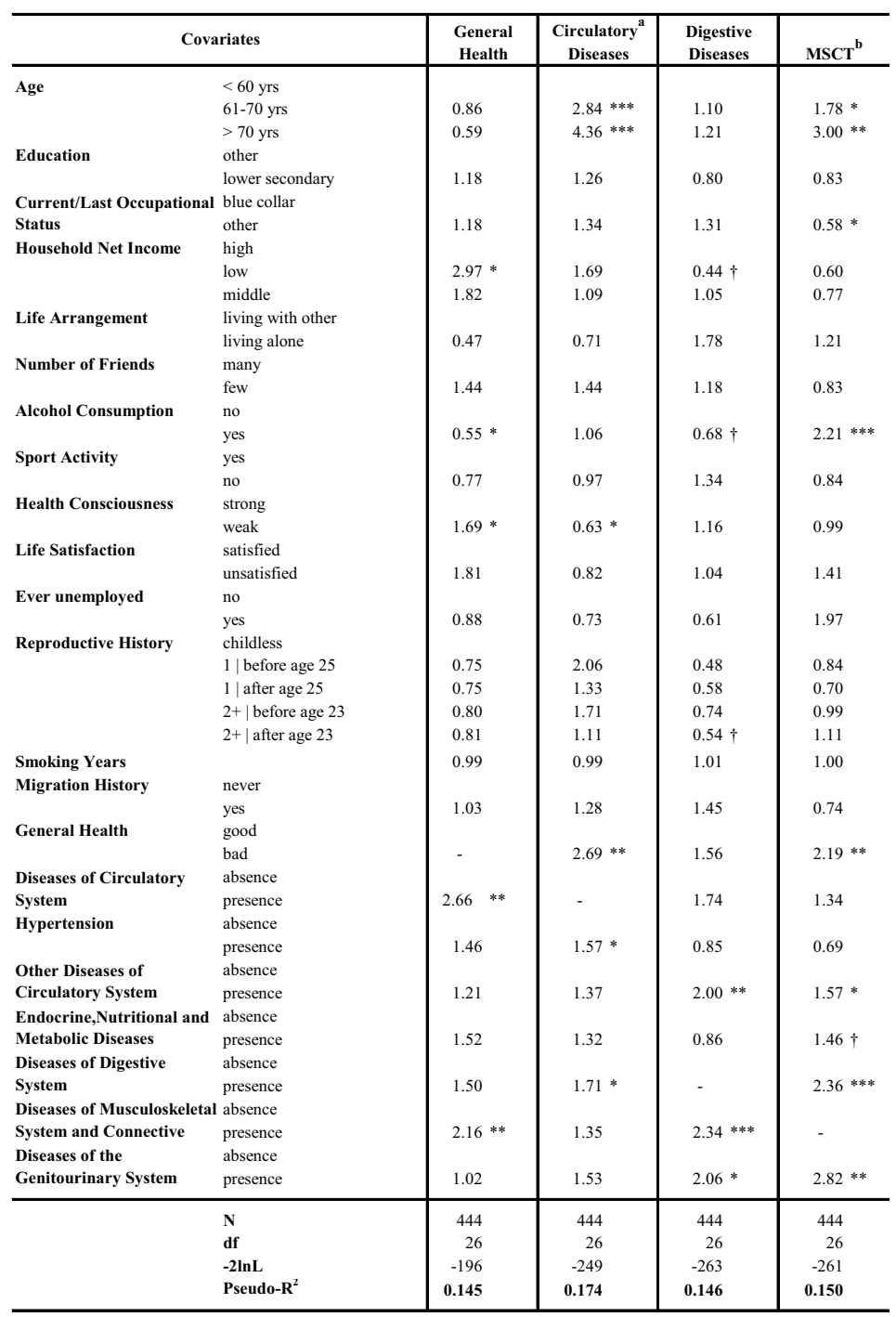

$\dagger \mathrm{p}<0.1,{ }^{*} \mathrm{p}<0.05,{ }^{* *} \mathrm{p}<0.01,{ }^{* * *} \mathrm{p}<0.001$

${ }^{a}$ Heart Diseases and Cerebralvascular Diseases

${ }^{\mathrm{b}}$ Diseases of Muscoloskeletal System and Connective Tissue 
Table 12: Results of logistic regression for general health status and diseases at baseline, males, eastern Germany

\begin{tabular}{|c|c|c|c|c|c|}
\hline \multicolumn{2}{|c|}{ Covariates } & $\begin{array}{l}\text { General } \\
\text { Health }\end{array}$ & $\begin{array}{c}\text { Circulatory } \\
\text { Diseases } \\
\end{array}$ & $\begin{array}{c}\text { Digestive } \\
\text { Diseases }\end{array}$ & MSCT $^{\mathbf{b}}$ \\
\hline Age & $\begin{array}{l}<60 \mathrm{yrs} \\
61-70 \mathrm{yrs} \\
>70 \mathrm{yrs}\end{array}$ & $\begin{array}{l}0.95 \\
1.45\end{array}$ & $\begin{array}{l}1.50 \\
2.20 \dagger\end{array}$ & $\begin{array}{l}0.72 \\
0.36 *\end{array}$ & $\begin{array}{l}0.83 \\
1.20\end{array}$ \\
\hline Education & $\begin{array}{l}\text { other } \\
\text { lower secondary }\end{array}$ & 0.64 & 1.38 & 0.77 & 0.49 \\
\hline $\begin{array}{l}\text { Current/Last Occupational } \\
\text { Status }\end{array}$ & $\begin{array}{l}\text { blue collar } \\
\text { other }\end{array}$ & 1.44 & 0.99 & 0.94 & 1.09 \\
\hline Household Net Income & $\begin{array}{l}\text { high } \\
\text { low } \\
\text { middle }\end{array}$ & $\begin{array}{l}0.73 \\
0.98\end{array}$ & $\begin{array}{l}1.20 \\
0.73\end{array}$ & $\begin{array}{l}0.99 \\
1.03\end{array}$ & $\begin{array}{l}0.75 \\
1.31\end{array}$ \\
\hline $\begin{array}{l}\text { Life Arrangement } \\
\text { Number of Friends }\end{array}$ & $\begin{array}{l}\text { living with other } \\
\text { living alone } \\
\text { many }\end{array}$ & 1.72 & 0.88 & 1.16 & 1.10 \\
\hline Alcohol Consumption & $\begin{array}{l}\text { few } \\
\text { no }\end{array}$ & 0.68 & 0.88 & 0.94 & 0.98 \\
\hline Sport Activity & $\begin{array}{l}\text { yes } \\
\text { yes }\end{array}$ & 0.72 & 0.59 & 1.00 & 1.63 \\
\hline Health Consciousness & $\begin{array}{l}\text { no } \\
\text { strong }\end{array}$ & $1.83 *$ & 0.89 & 0.96 & 1.14 \\
\hline Life Satisfaction & $\begin{array}{l}\text { weak } \\
\text { satisfied }\end{array}$ & 1.43 & 0.58 * & 0.88 & 0.97 \\
\hline Ever unemployed & $\begin{array}{l}\text { unsatisfied } \\
\text { no }\end{array}$ & $2.51 *$ & 0.84 & 0.77 & $1.98 *$ \\
\hline Reproductive History & $\begin{array}{l}\text { yes } \\
\text { childless }\end{array}$ & 1.00 & $0.30 *$ & 1.49 & 0.80 \\
\hline & $\begin{array}{l}1 \mid \text { before age } 25 \\
1 \mid \text { after age } 25 \\
2+\mid \text { before age } 23 \\
2+\mid \text { after age } 23\end{array}$ & $\begin{array}{l}0.78 \\
0.84 \\
0.67 \\
0.34 *\end{array}$ & $\begin{array}{l}0.67 \\
0.85 \\
0.57 \\
0.90\end{array}$ & $\begin{array}{l}5.63 * * \\
2.71 \dagger \\
1.69 \\
1.37\end{array}$ & $\begin{array}{l}0.36 \dagger \\
0.72 \\
0.45 \\
0.77\end{array}$ \\
\hline Smoking Status & $\begin{array}{l}\text { Smoking Years (Former) } \\
\text { Smoking Years (Current) }\end{array}$ & $\begin{array}{l}1.02 \\
1.02 \dagger\end{array}$ & $\begin{array}{l}1.00 \\
0.98 \dagger\end{array}$ & $\begin{array}{l}0.99 \\
0.99\end{array}$ & $\begin{array}{l}1.02 \\
1.01\end{array}$ \\
\hline Migration History & $\begin{array}{l}\text { never } \\
\text { yes }\end{array}$ & 1.11 & $1.92 *$ & 1.44 & 0.87 \\
\hline General Health & $\begin{array}{l}\text { good } \\
\text { bad }\end{array}$ & - & $2.16 *$ & 1.26 & 1.52 \\
\hline $\begin{array}{l}\text { Diseases of Circulatory } \\
\text { System } \\
\text { Hypertension }\end{array}$ & $\begin{array}{l}\text { absence } \\
\text { presence } \\
\text { absence }\end{array}$ & $2.27 *$ & - & 1.20 & 1.46 \\
\hline Other Diseases of & $\begin{array}{l}\text { presence } \\
\text { absence }\end{array}$ & $1.75 *$ & $1.82 *$ & 0.83 & 1.48 \\
\hline $\begin{array}{l}\text { Circulatory System } \\
\text { Endocrine,Nutritional and }\end{array}$ & $\begin{array}{l}\text { presence } \\
\text { absence }\end{array}$ & 1.61 & $2.06 *$ & $2.22 * *$ & $1.61 \dagger$ \\
\hline $\begin{array}{l}\text { Metabolic Diseases } \\
\text { Diseases of Digestive }\end{array}$ & $\begin{array}{l}\text { presence } \\
\text { absence }\end{array}$ & 1.24 & 1.01 & 1.08 & 1.30 \\
\hline System & presence & 1.18 & 1.23 & - & $4.10^{* * *}$ \\
\hline $\begin{array}{l}\text { System and Connective } \\
\text { Diseases of the } \\
\text { Genitourinary System }\end{array}$ & $\begin{array}{l}\text { presence } \\
\text { absence } \\
\text { presence }\end{array}$ & $\begin{array}{l}1.62 \dagger \\
1.33\end{array}$ & 1.45 & $\begin{array}{l}4.18^{* * *} \\
2.08 *\end{array}$ & $\begin{array}{l}- \\
0.83\end{array}$ \\
\hline & $\begin{array}{l}\text { N } \\
\text { df } \\
-2 \ln L \\
\text { Pseudo- } R^{2}\end{array}$ & $\begin{array}{r}361 \\
27 \\
-179 \\
\mathbf{0 . 1 5 4}\end{array}$ & $\begin{array}{r}361 \\
27 \\
-195 \\
\mathbf{0 . 1 7 5}\end{array}$ & $\begin{array}{r}361 \\
27 \\
-197 \\
\mathbf{0 . 1 6 8}\end{array}$ & $\begin{array}{r}361 \\
27 \\
-210 \\
\mathbf{0 . 1 6 1}\end{array}$ \\
\hline
\end{tabular}

$\dagger \mathrm{p}<0.1,{ }^{*} \mathrm{p}<0.05,{ }^{* *} \mathrm{p}<0.01,{ }^{* * *} \mathrm{p}<0.001$

${ }^{\mathrm{a}}$ Heart Diseases and Cerebralvascular Diseases

${ }^{b}$ Diseases of Muscoloskeletal System and Connective Tissue 


\subsection{Transitions in general health in western Germany}

The transition of the general health status between the two surveys of western German females is given in Table 13. The first columns with numbers present the transition risks from good general health at baseline to the new statuses of bad health, death and loss at or until follow-up. The last columns include the risks from bad general health status at baseline to the new statuses of good health, death or loss at or until follow-up. The risk of change from good to bad general health increased with age. The presence of endocrine, nutritional and metabolic diseases also increased the likelihood of experiencing a deterioration of general health, although the significance did not reach the five per cent level. A statistically significant lower risk of moving from good to bad general health between the two surveys was found for nonmarried females who live alone. The risk of experiencing an improvement of general health declined with age. Furthermore, being a housewife or a former smoker and the presence of heart diseases reduced the likelihood of health recovery (significance level was lower than 10 per cent). In contrast, high-proof alcohol consumption and earlier migration increased the risk of a health change from bad to good. The risk of dying was associated with the well-known risk factors at baseline, i.e. higher age, low household income groups and being a current smoker. Females with good health status at baseline had an additionally higher risk of dying when they had migrated and lived less than 10 years at their current place of residence. Furthermore, females with secondary education and blue-collar occupation also showed a higher risk of dying (significance level 10\%). Sports inactivity, the presence of heart diseases and hypertension were associated with a higher risk of dying among females with bad general health at baseline. In contrast, suffering from diseases of the musculoskeletal system and connective tissue at baseline reduced the risk of dying until follow-up. The risk of panel attrition increased with age for those respondents with good general health at baseline, as well as for females with middle and low income and for those inactive in sports.

Table 14 presents the corresponding transition rates for males from western Germany. The likelihood of transition from good to bad general health was significantly associated with the smoking status of the respondents. Each additional year of smoking increased the risk of experiencing health deterioration for former and current smokers by two per cent. Further indicators increasing the risk of moving from good to bad general health were having only primary education and the presence of diseases of the digestive system at baseline (significance level lower than 10\%). Lower odds of developing bad health were related to later fatherhood of three or more children. Migration background and permanent residence for 30 years or more were also positively associated with remaining in good general health. "Recovery transitions" from bad to good general health were unlikely for males who were inactive in sports and for those who reported the experience of heart diseases at baseline. Further indicators for transition to good health status at the 10 per cent significant level were secondary education, dissatisfaction with life and experience with unemployment. The risk of mortality increased with age, especially for those reporting bad general health at baseline. Smoking also increased the likelihood of dying for current as well as for former smokers, regardless of the baseline status of general health. The presence of respiratory diseases was also associated with higher risk of dying. The impact of health consciousness showed a 
diverse picture. Males with good general health at baseline who cared only little about their health had a higher likelihood of dying during follow-up. However, males in bad general health at baseline who reported a low health consciousness had a significantly lower risk of dying. Further risk factors for dying were bad general health at baseline in conjunction with the presence of heart diseases or hypertension. The results of panel attrition mainly reveal the loss of current smokers, regardless of their specific characteristics at the time of the first survey. Furthermore, males who were dissatisfied with their lives as well as those with primary education only were more likely to get lost between the two survey waves.

\subsection{Transitions in disease and multimorbidity status in western Germany}

The analysis of transitions in disease and multimorbidity statuses is focused on the one-way change from the absence to the presence of specific diseases and multimorbidity, respectively, and the competing risk factors of death and attrition between the two surveys. The latter might explain lacking significance of theoretically expected risk factors for the disease transitions. Table 15 shows the transition risks from absence of specific diseases at baseline to death for females. Additionally, the last column presents the change from absence of multimorbidity to death. The risk of dying increased with age. Secondary education, low and middle household income as well as sports inactivity significantly increased the likelihood, too. Furthermore, current smoking at baseline was associated with an increased risk of dying - the risk increasing by three per cent per additional smoking year. The presence of heart diseases and hypertension at baseline were also significantly related to a higher mortality risk. An increased risk for the transition from the absence of specific diseases at baseline to loss until follow up was statistically significant for the highest age group. Moreover, females with secondary as well as primary education, those who are self-employed or inactive in sports or received a low or middle net household income at baseline were likely to get lost during follow-up as well (Table 16). A reduced risk of attrition was found only for low health consciousness.

Table 17 presents the transition rates from absence to presence of specific diseases and multimorbidity. The risk of developing heart diseases between the two surveys was statistically significantly higher for females in the highest age group, sports-inactive women, current smokers and females with migration background but with permanent residence for 20 years or more. Note again that all characteristics of the covariates refer to the time of the first survey. The highest age group and current smoking were also associated with the risk of developing cerebrovascular diseases. The onset of diseases of the respiratory system between the two surveys was only significant for current smoking at baseline. Secondary education and the earlier presence of heart diseases increased the odds of developing diseases of the digestive system. The risk was lower for women in blue-collar occupations and housewives as compared to white-collar occupations. Furthermore, current smoking was associated with a higher likelihood of developing diseases of the digestive system, but only at the 10 per cent significance level. The risk of getting diseases of the musculoskeletal system and connective tissue during the follow-up time was higher among females with strong type A behaviour. The earlier presence of hypertension and diseases of the respiratory system were also associated 
with a higher likelihood for developing that disease. The onset of multimorbidity was most likely for women of the oldest age group and for females with experience of unemployment. Further, the presence of other diseases of the circulatory system and diseases of the musculoskeletal system and connective tissue at baseline also increased risk of suffering from multimorbidity at the time of the second survey.

The risk factors for the mortality of males are given in Table 18. Age, self-employment, sports inactivity and current as well as former smoking at baseline were associated with a higher risk of dying. Bad general health and the presence of heart diseases, of hypertension and of diseases of the respiratory system at baseline increased the likelihood of dying as well. A protective effect against mortality was found for later fatherhood of two children. The risk factors of attrition can be found in Table 19. The risk of attrition was higher for self-employed males, those who were unsatisfied with their lives and current smokers. In contrast, civil servants and a strong type A behaviour reduced the likelihood of loss during the follow-up.

The transitions to the presence of diseases and multimorbidity of males given the absence of these disease statuses at baseline are presented in Table 20. Surprisingly, all analysed diseases did not show any association with age. However, the risk of developing multimorbidity between the two surveys was statistically significant for all age groups. The risk of developing heart diseases was higher for males with overweight, low net household income, as well as for former and current (significance level of 10\%) smokers and for males who reported diseases of the digestive system at the first survey. In contrast, primary education reduced the risk of developing heart diseases. The likelihood of the onset of cerebrovascular diseases was associated with the presence of diseases of the digestive system at baseline. Furthermore, an earlier presence of heart diseases and endocrine, nutritional and metabolic diseases increased also the risk of developing cerebrovascular diseases, but the significance did not reach the five per cent level. In contrast, earlier fatherhood of one child reduced the risk of cerebrovascular diseases. The risk of getting diseases of the respiratory system was associated with low net household income. Being overweight, sports inactivity and a former smoking status were also related to a higher likelihood of developing respiratory diseases, but only at the 10 per cent significance level. Having been unemployed at some point in life was only significantly associated with a higher likelihood of developing diseases of the digestive system. Also regarding digestive diseases, former smoking as well as the earlier presence of heart diseases led to an increased risk, however, without reaching the five per cent significance level. Diseases of the musculoskeletal system and connective tissue were more likely for males with a low net household income and the presence of diseases of the digestive system at baseline. Apart from the aforementioned age effect, the risk of developing multimorbidity was associated with overweight, earlier experiences with unemployment and bad general health at baseline. On the other hand, blue-collar occupations, a strong type A behaviour and young fatherhood of one child resulted in a lower likelihood of suffering from the co-occurrence of diseases at the time of the second survey among those who did not report multimorbidity at baseline. 
Table 13: Results of multinomial logistic regression for transitions of general health, females, western Germany

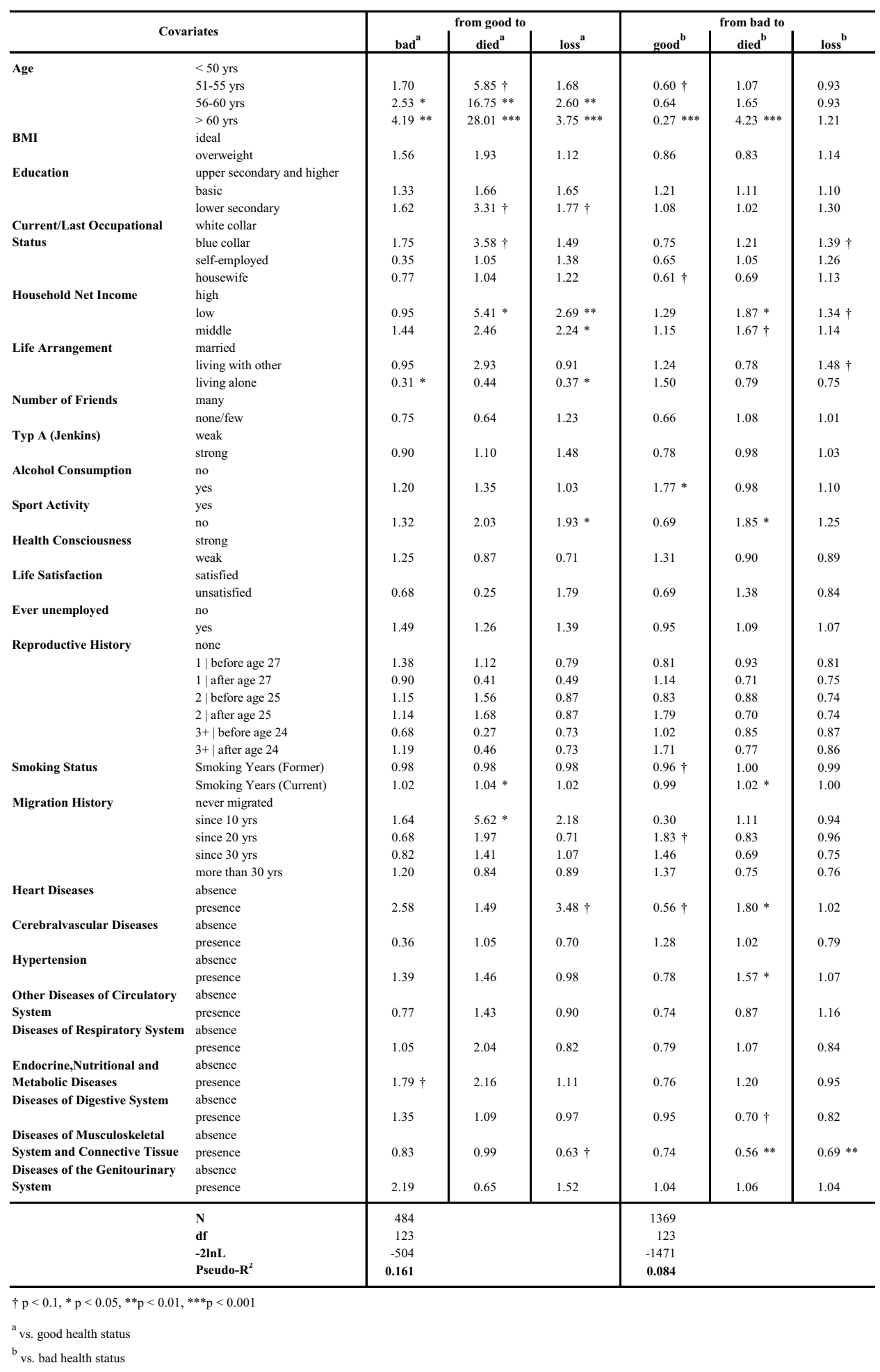


Table 14: Results of multinomial logistic regression for transitions of general health, males, western Germany

\begin{tabular}{|c|c|c|c|c|c|c|c|}
\hline \multicolumn{2}{|c|}{ Covariates } & \multicolumn{3}{|c|}{ from good to } & \multicolumn{3}{|c|}{ from bad to } \\
\hline \multirow{4}{*}{ Age } & $<50 \mathrm{yrs}$ & & & & & & \\
\hline & $51-55 \mathrm{yrs}$ & 0.89 & 1.12 & 0.95 & 1.38 & 1.35 & 0.75 \\
\hline & $56-60 \mathrm{yrs}$ & 1.14 & $2.33 *$ & 1.18 & 0.99 & $1.75 *$ & 1.12 \\
\hline & $>60 \mathrm{yrs}$ & 0.77 & 1.81 & 0.88 & 0.59 & $2.72 * * *$ & 0.87 \\
\hline \multirow[t]{2}{*}{ BMI } & ideal & & & & & & \\
\hline & overweight & 1.17 & 1.03 & 1.00 & 0.69 & $0.70 *$ & 0.93 \\
\hline \multirow[t]{3}{*}{ Education } & high & & & & & & \\
\hline & primary & $8.53 \dagger$ & $8.34 \dagger$ & $8.09 \dagger$ & 0.58 & 0.92 & $1.79 \dagger$ \\
\hline & secondary & 0.96 & 1.29 & 0.82 & $0.62 \dagger$ & 1.22 & 1.29 \\
\hline \multirow{4}{*}{$\begin{array}{l}\text { Current/Last Occupational } \\
\text { Status }\end{array}$} & white collar & & & & & & \\
\hline & blue collar & 1.30 & 1.06 & 1.35 & 1.05 & 1.40 & 1.16 \\
\hline & civil servants & 1.68 & 1.45 & 0.71 & 0.59 & 1.10 & $0.54 *$ \\
\hline & self-employed & 1.15 & 1.51 & 1.55 & 1.04 & 1.35 & $1.63 *$ \\
\hline \multirow[t]{3}{*}{ Household Net Income } & high & & & & & & \\
\hline & low & 1.20 & 1.49 & 1.30 & 0.68 & 1.15 & 0.79 \\
\hline & middle & 0.97 & 1.22 & 1.42 & 0.98 & 0.96 & 0.90 \\
\hline \multirow[t]{3}{*}{ Life Arrangement } & married & & & & & & \\
\hline & living with other & 0.56 & $2.67 \dagger$ & 0.87 & 1.87 & 1.30 & 1.21 \\
\hline & living alone & 2.76 & 2.33 & 1.68 & 1.29 & $2.03 \dagger$ & $1.98 \dagger$ \\
\hline \multirow[t]{2}{*}{ Number of Friends } & many & & & & & & \\
\hline & none/few & 1.17 & 1.44 & 1.12 & 1.48 & 1.02 & 1.22 \\
\hline Typ A (Jenkins) & weak & & & & & & \\
\hline & strong & 1.01 & 0.70 & 0.78 & 1.16 & $0.74 \dagger$ & 0.82 \\
\hline Alcohol Consumption & no & & & & & & \\
\hline & yes & 1.37 & 1.37 & 1.10 & 0.85 & 1.03 & 0.87 \\
\hline Sport Activity & yes & & & & & & \\
\hline & no & 1.31 & 1.58 & 1.20 & $0.60 *$ & 1.16 & 1.04 \\
\hline Health Consciousness & strong & & & & & & \\
\hline & weak & 1.49 & $1.81 *$ & 1.22 & 0.83 & $0.61 * *$ & $0.72 *$ \\
\hline Life Satisfaction & satisfied & & & & & & \\
\hline & unsatisfied & 2.33 & 0.38 & $2.96 *$ & $0.51 \dagger$ & 1.05 & 1.09 \\
\hline Ever unemployed & no & & & & & & \\
\hline & yes & 1.36 & 0.97 & 1.19 & $0.60 \dagger$ & 1.04 & 0.80 \\
\hline Reproductive History & none & & & & & & \\
\hline & 1 | before age 30 & 0.94 & 1.35 & 0.50 & $2.34 \dagger$ & 1.43 & 1.45 \\
\hline & $1 \mid$ after age 30 & 0.76 & 0.85 & 0.67 & 1.73 & 1.00 & 1.32 \\
\hline & $2 \mid$ before age 28 & 0.81 & 1.03 & 0.74 & 1.11 & 0.75 & 1.27 \\
\hline & $2 \mid$ after age 28 & 0.75 & 0.83 & $0.50 \dagger$ & 1.71 & 0.69 & 1.12 \\
\hline & $3+\mid$ before age 26 & 1.10 & 1.51 & 0.70 & 0.89 & 0.72 & $2.27 * *$ \\
\hline & $3+\mid$ after age 26 & $0.45 *$ & 0.59 & $0.40 * *$ & 1.44 & 0.97 & 1.44 \\
\hline Smoking Status & Smoking Years (Former) & $1.02 *$ & $1.03 \dagger$ & 1.01 & 1.00 & $1.03 * * *$ & 1.00 \\
\hline & Smoking Years (Current) & $1.02 * *$ & $1.05^{* * *}$ & $1.02 *$ & 0.99 & $1.04 * * *$ & $1.01 *$ \\
\hline Migration History & never migrated & & & & & & \\
\hline & since $10 \mathrm{yrs}$ & 0.60 & 0.76 & 0.68 & 0.57 & 0.85 & 0.80 \\
\hline & since $20 \mathrm{yrs}$ & $0.56 \dagger$ & 1.01 & 1.06 & 0.71 & 0.72 & 1.13 \\
\hline & since $30 \mathrm{yrs}$ & $0.47 *$ & 0.73 & 0.75 & 0.66 & 0.84 & 0.87 \\
\hline & more than $30 \mathrm{yrs}$ & 0.97 & 1.04 & 0.73 & 0.97 & 1.03 & 1.09 \\
\hline Heart Diseases & absence & & & & & & \\
\hline & presence & 1.02 & 1.64 & 1.84 & $0.53 *$ & $1.51 *$ & 0.93 \\
\hline Cerebralvascular Diseases & absence & & & & & & \\
\hline & presence & 1.08 & 2.68 & 0.25 & 0.85 & 1.03 & 0.96 \\
\hline Hypertension & absence & & & & & & \\
\hline & presence & 1.53 & 1.73 & 0.65 & 0.89 & $1.52 *$ & 1.28 \\
\hline Other Diseases of Circulatory & absence & & & & & & \\
\hline & presence & 0.90 & 0.86 & 0.98 & 0.91 & 0.99 & $1.36 *$ \\
\hline Diseases of Respiratory System & absence & & & & & & \\
\hline & presence & 0.97 & $2.40 *$ & 0.85 & 1.05 & $1.52 *$ & 1.18 \\
\hline Endocrine,Nutritional \& & absence & & & & & & \\
\hline & presence & 1.30 & 0.57 & 1.12 & 0.98 & 1.33 & 0.84 \\
\hline Diseases of Digestive System & absence & & & & & & \\
\hline & presence & $1.55 \dagger$ & 1.60 & 1.09 & 0.92 & 0.85 & 1.02 \\
\hline Diseases of Musculoskeletal & absence & & & & & & \\
\hline System and Connective Tissue & presence & 0.90 & 0.78 & 0.97 & 0.76 & $0.67 *$ & 1.04 \\
\hline Diseases of the Genitourinary & absence & & & & & & \\
\hline System & presence & 1.61 & 1.11 & 0.95 & 0.72 & 0.89 & 0.88 \\
\hline & $\mathbf{N}$ & 730 & & & 1325 & & \\
\hline & df & 123 & & & 123 & & \\
\hline & $-2 \operatorname{lnL}$ & -872 & & & -1519 & & \\
\hline & Pseudo- $\mathrm{R}^{2}$ & 0.109 & & & 0.112 & & \\
\hline
\end{tabular}


Table 15: Results of multinomial logistic regression for the transition from absence of specific diseases to death, females, western Germany

\begin{tabular}{|c|c|c|c|c|c|c|c|}
\hline \multicolumn{2}{|c|}{ Covariates } & $\begin{array}{c}\begin{array}{c}\text { Heart } \\
\text { Diseases }\end{array} \\
\end{array}$ & $\begin{array}{c}\text { Cerebralvasc. } \\
\text { Diseases }\end{array}$ & $\begin{array}{c}\text { Respiratory } \\
\text { Diseases }\end{array}$ & \multirow[t]{2}{*}{$\begin{array}{l}\text { Digestive } \\
\text { Diseases }\end{array}$} & \multirow[t]{2}{*}{ MSCT $^{\mathbf{a}}$} & \multirow[t]{2}{*}{$\begin{array}{c}\text { Multi- } \\
\text { morbidity }\end{array}$} \\
\hline Age & $<50 \mathrm{yrs}$ & & & & & & \\
\hline & $51-55 \mathrm{yrs}$ & 1.31 & 1.79 & 1.43 & 1.76 & 0.88 & 1.42 \\
\hline & $56-60 \mathrm{yrs}$ & $3.40 * *$ & $3.34 * * *$ & $2.42 *$ & $5.30 * *$ & $2.84 *$ & $3.68 * *$ \\
\hline & $>60 \mathrm{yrs}$ & $9.91 * * *$ & $7.95 * * *$ & $7.36 * * *$ & $12.31 * * *$ & $8.52 * * *$ & $9.18 * * *$ \\
\hline \multirow[t]{2}{*}{ BMI } & ideal & & & & & & \\
\hline & overweight & 1.29 & 1.02 & 1.06 & 1.11 & 1.00 & 1.21 \\
\hline \multirow[t]{3}{*}{ Education } & high & & & & & & \\
\hline & primary & $2.76^{* *}$ & 1.50 & 1.62 & 1.75 & 2.00 & $2.11 *$ \\
\hline & secondary & $1.93 *$ & 1.39 & 1.50 & $2.11 *$ & $2.42 *$ & $1.74 \dagger$ \\
\hline Current/Last Occupational & white collar & & & & & & \\
\hline Status & blue collar & 0.88 & 1.10 & 1.38 & 1.01 & 1.02 & 0.98 \\
\hline & self-employed & 1.26 & 1.16 & 1.40 & 2.14 & 0.83 & 1.78 \\
\hline & housewife & $0.56 \dagger$ & 0.78 & 0.93 & 0.76 & 0.89 & 0.77 \\
\hline Household Net Income & high & & & & & & \\
\hline & low & $2.11 *$ & $2.46^{* *}$ & $1.96 *$ & 1.85 & $2.57 *$ & $2.27 *$ \\
\hline & middle & 1.62 & $1.76 *$ & $1.61 \dagger$ & 1.34 & $1.97 \dagger$ & 1.64 \\
\hline Life Arrangement & married & & & & & & \\
\hline & living with other & 0.71 & 0.99 & 0.81 & 1.11 & 1.28 & 1.02 \\
\hline & living alone & 0.72 & 0.76 & 0.75 & 0.80 & 0.82 & 0.83 \\
\hline Number of Friends & many & & & & & & \\
\hline & none/few & 1.07 & 1.11 & 1.26 & 1.24 & 1.40 & 1.20 \\
\hline Typ A (Jenkins) & weak & & & & & & \\
\hline & strong & 1.13 & 1.06 & 1.03 & 0.91 & $1.96 *$ & 1.12 \\
\hline Alcohol Consumption & no & & & & & & \\
\hline & yes & 0.85 & 0.88 & 0.79 & 1.08 & 0.59 & 0.80 \\
\hline Sport Activity & yes & & & & & & \\
\hline & no & $2.41 * *$ & $2.09 * *$ & $1.94 * *$ & $2.56 * *$ & $2.20 \dagger$ & $2.67^{* * *}$ \\
\hline Health Consciousness & strong & & & & & & \\
\hline & weak & 0.84 & 0.76 & 0.84 & 0.87 & $0.56 \dagger$ & 0.81 \\
\hline Life Satisfaction & satisfied & & & & & & \\
\hline & unsatisfied & 1.03 & 1.47 & 1.12 & 1.40 & 1.56 & 1.13 \\
\hline Ever unemployed & no & & & & & & \\
\hline & yes & 1.24 & 1.07 & 1.29 & 1.29 & 1.38 & 1.11 \\
\hline Reproductive History & none & & & & & & \\
\hline & 1 | before age 27 & 1.00 & 1.09 & 0.85 & 1.23 & 1.36 & 1.12 \\
\hline & $1 \mid$ after age 27 & 0.71 & 0.84 & 0.65 & 1.02 & 1.40 & 0.70 \\
\hline & $2 \mid$ before age 25 & 1.01 & 1.04 & 0.96 & 1.22 & 0.64 & 0.85 \\
\hline & $2 \mid$ after age 25 & 1.13 & 0.98 & 0.81 & 1.32 & 1.54 & 1.01 \\
\hline & $3+\mid$ before age 24 & 0.89 & 1.08 & 0.64 & 1.08 & 1.01 & 0.75 \\
\hline & $3+\mid$ after age 24 & 0.86 & 0.80 & 0.81 & 0.86 & 0.80 & 0.85 \\
\hline Smoking Status & Smoking Years (Former) & 1.01 & 1.00 & 1.00 & 0.99 & 1.02 & 1.02 \\
\hline & Smoking Years (Current) & $1.03^{* * *}$ & $1.03 * * *$ & $1.03 * * *$ & $1.03 * *$ & $1.03 * *$ & $1.03^{* * * *}$ \\
\hline Migration History & never migrated & & & & & & \\
\hline & since $10 \mathrm{yrs}$ & $2.09 \dagger$ & $1.87 \dagger$ & 1.37 & 1.37 & 1.40 & $2.10 \dagger$ \\
\hline & since $20 \mathrm{yrs}$ & 0.82 & 0.86 & 0.85 & 0.71 & $0.30 *$ & 0.90 \\
\hline & since $30 \mathrm{yrs}$ & 0.95 & 0.76 & 0.75 & 1.27 & 0.66 & 0.81 \\
\hline & more than $30 \mathrm{yrs}$ & 0.67 & $0.63 \dagger$ & $0.63 \dagger$ & 0.75 & $0.43 *$ & 0.63 \\
\hline General Health Status & good & & & & & & \\
\hline & bad & 1.31 & 1.31 & 1.40 & 1.55 & 1.48 & 1.47 \\
\hline Heart Diseases & absence & & & & & & \\
\hline & presence & - & $1.74 *$ & 1.44 & $2.77^{* *}$ & 1.29 & - \\
\hline Cerebralvascular Diseases & absence & & & & & & \\
\hline & presence & 1.08 & - & 1.22 & 0.50 & 1.66 & - \\
\hline Hypertension & absence & & & & & & \\
\hline & presence & $1.88 *$ & 1.29 & 1.41 & 1.29 & $2.21 *$ & $1.52 \dagger$ \\
\hline Other Diseases of & absence & & & & & & \\
\hline Circulatory System & presence & 0.98 & 1.08 & 0.94 & 0.93 & 0.82 & 1.07 \\
\hline Diseases of Respiratory & absence & & & & & & \\
\hline System & presence & 0.60 & 1.17 & - & 0.84 & $6.06 * *$ & - \\
\hline Endocrine,Nutritional \& & absence & & & & & & \\
\hline Metabolic Diseases & presence & 1.14 & 1.16 & $1.40 \dagger$ & 1.16 & 1.44 & 1.13 \\
\hline Diseases of Digestive & absence & & & & & & \\
\hline System & presence & 0.84 & $0.66 *$ & 0.74 & - & 1.06 & - \\
\hline Diseases of Musculoskeletal & 1 absence & & & & & & \\
\hline System and Connective & presence & 0.78 & 0.75 & 0.82 & 0.88 & - & 0.95 \\
\hline Diseases of the & absence & & & & & & \\
\hline Genitourinary System & presence & 0.98 & 1.00 & 0.81 & 1.19 & 1.42 & 0.75 \\
\hline & $\mathbf{N}$ & 1454 & 1666 & 1678 & 952 & 826 & 1454 \\
\hline & df & 123 & 123 & 123 & 123 & 123 & 114 \\
\hline & $-2 \operatorname{lnL}$ & -1497 & -1655 & -1607 & -964 & -887 & -1540 \\
\hline & Pseudo- $\mathrm{R}^{2}$ & 0.087 & 0.084 & 0.087 & 0.116 & 0.122 & 0.088 \\
\hline
\end{tabular}

$\dagger \mathrm{p}<0.1,{ }^{*} \mathrm{p}<0.05, * * \mathrm{p}<0.01,{ }^{* * *} \mathrm{p}<0.00$

${ }^{\mathrm{a}}$ Diseases of Muscoloskeletal System and Connective Tissue 
Table 16: Results of multinomial logistic regression for the transition from absence of specific diseases to attrition, females, western Germany

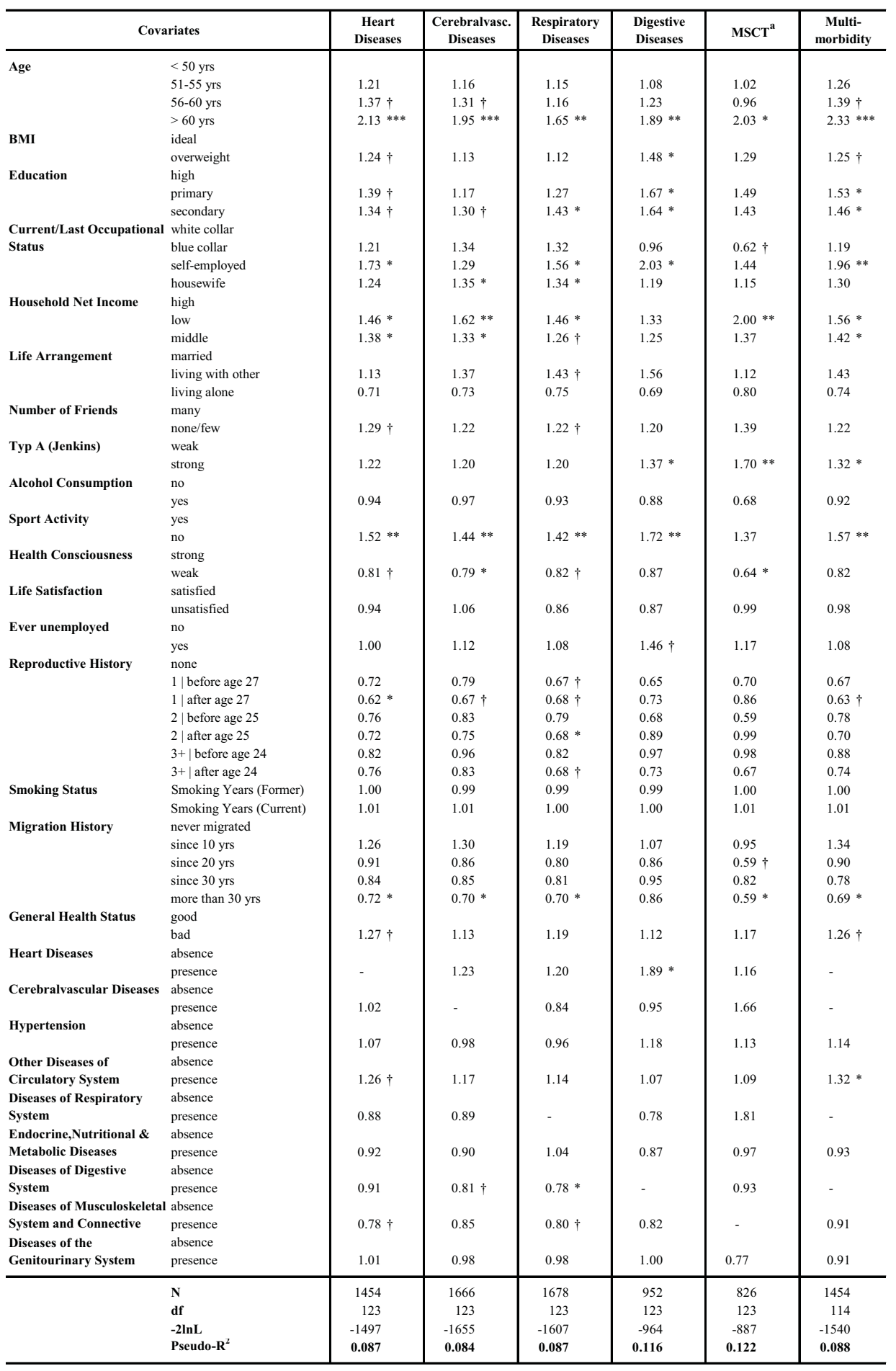

$\dagger \mathrm{p}<0.1,{ }^{*} \mathrm{p}<0.05, * * \mathrm{p}<0.01,{ }^{* * *} \mathrm{p}<0.00$

${ }^{\mathrm{a}}$ Diseases of Muscoloskeletal System and Connective Tissue 
Table 17: Results of multinomial logistic regression for the transition from the absence to the presence of specific diseases, females, western Germany

\begin{tabular}{|c|c|c|c|c|c|c|c|}
\hline \multicolumn{2}{|c|}{ Covariates } & \multirow[t]{2}{*}{$\begin{array}{c}\text { Heart } \\
\text { Diseases }\end{array}$} & \multirow[t]{2}{*}{\begin{tabular}{|c|}
$\begin{array}{c}\text { Cerebralvasc. } \\
\text { Diseases }\end{array}$ \\
\end{tabular}} & \multirow[t]{2}{*}{$\begin{array}{c}\text { Respiratory } \\
\text { Diseases }\end{array}$} & \multirow[t]{2}{*}{$\begin{array}{c}\text { Digestive } \\
\text { Diseases }\end{array}$} & \multirow[t]{2}{*}{$\operatorname{MSCT}^{\mathrm{a}}$} & \multirow[t]{2}{*}{$\begin{array}{c}\text { Multi- } \\
\text { morbidity }\end{array}$} \\
\hline Age & $<50 \mathrm{yrs}$ & & & & & & \\
\hline & $51-55 \mathrm{yrs}$ & 1.30 & 1.43 & 0.75 & 0.93 & 1.02 & 1.54 \\
\hline & $56-60 \mathrm{yrs}$ & $1.90 \dagger$ & 0.98 & $0.41 \dagger$ & 0.52 & 0.93 & 1.53 \\
\hline & $>60 \mathrm{yrs}$ & $3.66 * * *$ & $3.43 * *$ & 0.62 & $2.06 \dagger$ & 1.53 & $3.37 * * *$ \\
\hline \multirow[t]{2}{*}{ BMI } & ideal & & & & & & \\
\hline & overweight & 1.42 & 1.47 & 1.35 & $1.63 \dagger$ & 1.16 & 1.15 \\
\hline \multirow[t]{3}{*}{ Education } & high & & & & & & \\
\hline & primary & 1.23 & 0.89 & 1.91 & 1.98 & 1.36 & 1.60 \\
\hline & secondary & 1.15 & 0.73 & $2.03 \dagger$ & $2.21 *$ & 0.95 & 1.21 \\
\hline Current/Last Occupationa & I white collar & & & & & & \\
\hline Status & blue collar & 0.69 & 0.64 & 0.66 & $0.39 *$ & 0.64 & 0.73 \\
\hline & self-employed & 1.57 & 0.56 & 1.06 & 0.74 & 0.91 & 1.62 \\
\hline & housewife & 0.85 & 0.71 & 0.88 & $0.46 *$ & 0.93 & 0.77 \\
\hline Household Net Income & high & & & & & & \\
\hline & low & 1.07 & 1.04 & 0.81 & 0.79 & 0.94 & 1.11 \\
\hline & middle & 1.25 & 1.15 & 0.76 & 1.16 & 0.86 & 1.22 \\
\hline Life Arrangement & married & & & & & & \\
\hline & living with other & 0.69 & 1.53 & 1.82 & 0.43 & 0.79 & 1.22 \\
\hline & living alone & 0.73 & 0.89 & $2.30 \dagger$ & 0.99 & 1.36 & 0.85 \\
\hline Number of Friends & many & & & & & & \\
\hline & none/few & 1.39 & 0.89 & 1.39 & 0.84 & 1.37 & 1.07 \\
\hline Typ A (Jenkins) & weak & & & & & & \\
\hline & strong & 1.02 & 1.32 & 0.82 & 0.97 & $2.17 * *$ & 1.34 \\
\hline Alcohol Consumption & no & & & & & & \\
\hline & yes & $0.55 \dagger$ & 0.67 & $0.36 \dagger$ & 0.51 & $0.51 \dagger$ & $0.61 \dagger$ \\
\hline Sport Activity & yes & & & & & & \\
\hline & no & $1.71 *$ & 1.16 & 0.72 & 1.16 & 0.86 & 1.34 \\
\hline Health Consciousness & strong & & & & & & \\
\hline & weak & 0.98 & 0.87 & 1.54 & 0.76 & 0.81 & 1.07 \\
\hline Life Satisfaction & satisfied & & & & & & \\
\hline & unsatisfied & 1.03 & 1.45 & 0.89 & 1.05 & 1.09 & 1.14 \\
\hline Ever unemployed & no & & & & & & \\
\hline & yes & 0.93 & 1.23 & 1.15 & 1.76 & 1.44 & $1.68 *$ \\
\hline Reproductive History & none & & & & & & \\
\hline & $1 \mid$ before age 27 & 1.28 & 1.33 & 0.53 & 1.18 & 1.34 & 0.83 \\
\hline & $1 \mid$ after age 27 & 0.73 & 0.47 & 0.44 & 1.38 & 0.89 & 0.59 \\
\hline & $2 \mid$ before age 25 & 1.90 & 1.50 & 1.00 & 1.33 & 0.66 & 0.99 \\
\hline & 2 | after age 25 & 1.78 & 1.52 & 0.80 & 1.36 & 1.07 & 1.24 \\
\hline & $3+\mid$ before age 24 & 1.72 & 1.58 & 0.66 & 1.36 & 1.01 & 1.04 \\
\hline & $3+\mid$ after age 24 & 1.42 & 0.97 & 0.46 & 1.28 & 0.64 & 1.04 \\
\hline Smoking Status & Smoking Years (Former) & 1.02 & 0.99 & 1.02 & 0.99 & 1.01 & 1.01 \\
\hline & Smoking Years (Current) & $1.02 * *$ & $1.02 *$ & $1.03 *$ & $1.02 \dagger$ & 1.01 & 1.01 \\
\hline Migration History & never migrated & & & & & & \\
\hline & since $10 \mathrm{yrs}$ & 1.67 & 2.23 & 0.34 & 0.96 & 0.93 & 1.65 \\
\hline & since $20 \mathrm{yrs}$ & $2.00 *$ & 1.28 & 0.55 & 1.12 & $0.39 *$ & 1.42 \\
\hline & since $30 \mathrm{yrs}$ & 1.61 & $1.94 \dagger$ & $2.22 \dagger$ & 1.45 & 0.91 & 1.18 \\
\hline & more than $30 \mathrm{yrs}$ & 1.03 & 1.28 & 1.67 & 0.95 & 0.78 & 1.04 \\
\hline General Health Status & good & & & & & & \\
\hline & bad & 1.34 & 0.86 & 1.19 & 1.24 & 1.04 & 1.31 \\
\hline Heart Diseases & absence & & & & & & \\
\hline & presence & - & 0.98 & 1.34 & $2.79 * *$ & 0.93 & - \\
\hline Cerebralvascular Diseases & absence & & & & & & \\
\hline & presence & 1.30 & - & 1.27 & 0.90 & 0.27 & - \\
\hline Hypertension & absence & & & & & & \\
\hline & presence & 1.39 & 0.79 & 0.55 & 0.73 & $2.00 *$ & 1.32 \\
\hline Other Diseases of & absence & & & & & & \\
\hline Circulatory System & presence & 1.37 & 1.32 & 1.00 & 1.26 & 0.93 & $1.76 * *$ \\
\hline Diseases of Respiratory & absence & & & & & & \\
\hline System & presence & 1.16 & $2.07 \dagger$ & - & 0.86 & $3.02 *$ & - \\
\hline Endocrine,Nutritional \& & absence & & & & & & \\
\hline Metabolic Diseases & presence & 0.97 & 0.74 & 1.68 & 1.35 & 0.97 & 0.90 \\
\hline Diseases of Digestive & absence & & & & & & \\
\hline System & presence & 1.40 & 0.98 & $0.54 \dagger$ & - & $1.58 \dagger$ & - \\
\hline Diseases of Musculoskelet: & I absence & & & & & & \\
\hline System and Connective & presence & 1.23 & 1.27 & $1.90 \dagger$ & 1.65 & - & $1.84 * *$ \\
\hline Diseases of the & absence & & & & & & \\
\hline Genitourinary System & presence & 1.25 & 0.99 & 1.79 & 1.54 & 1.52 & 1.37 \\
\hline & $\mathbf{N}$ & 1454 & 1666 & 1678 & 952 & 826 & 1454 \\
\hline & df & 123 & 123 & 123 & 123 & 123 & 114 \\
\hline & $-2 \operatorname{lnL}$ & -1497 & -1655 & -1607 & -964 & -887 & -1540 \\
\hline & Pseudo-R ${ }^{2}$ & 0.087 & 0.084 & 0.087 & 0.116 & 0.122 & 0.088 \\
\hline
\end{tabular}


Table 18: Results of multinomial logistic regression for the transition from the absence of specific diseases to death, males, western Germany

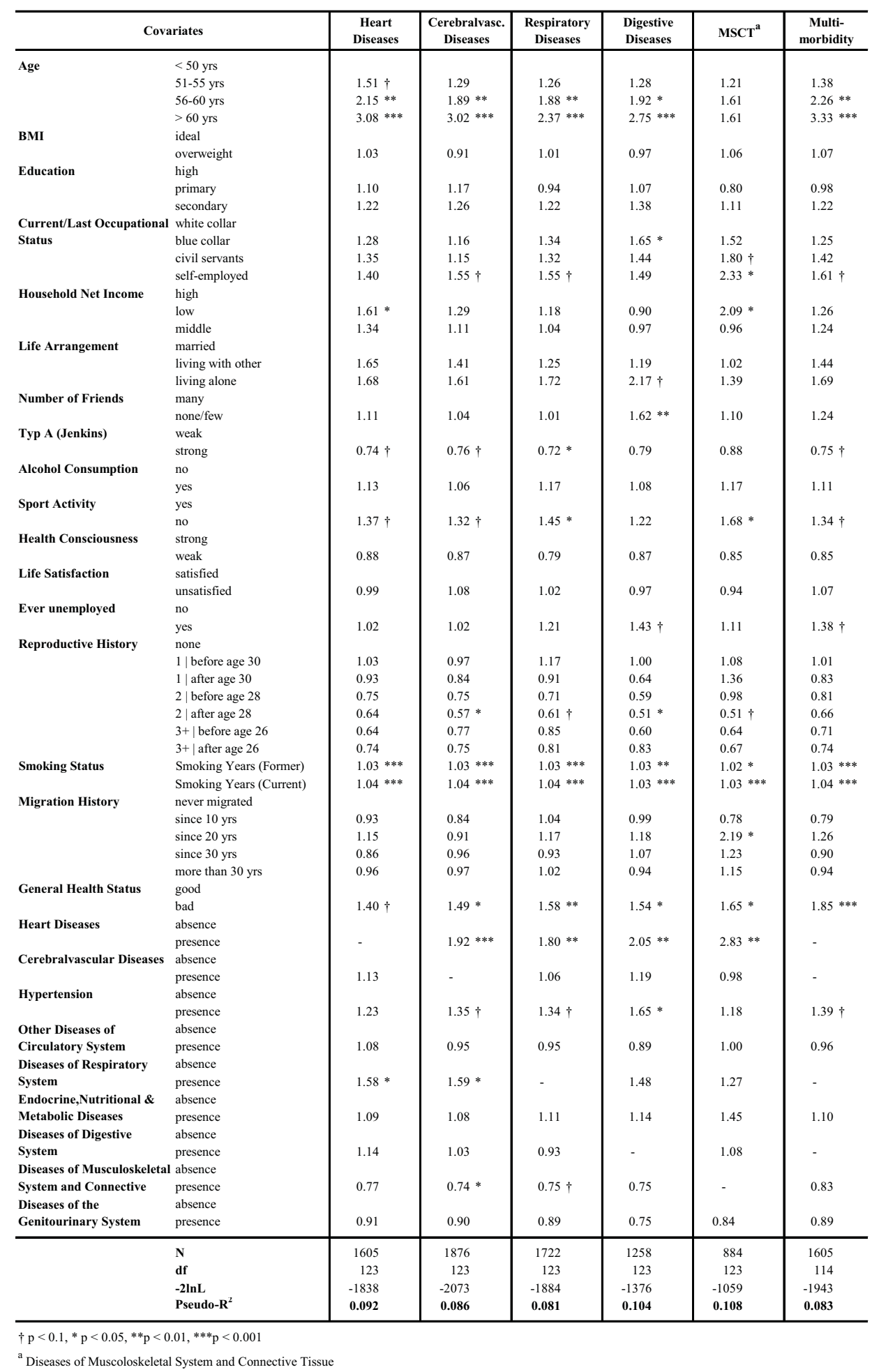


Table 19: Results of multinomial logistic regression for the transition from the absence of specific diseases to attrition, males, western Germany

\begin{tabular}{|c|c|c|c|c|c|c|c|}
\hline \multicolumn{2}{|c|}{ Covariates } & $\begin{array}{c}\begin{array}{c}\text { Heart } \\
\text { Diseases }\end{array} \\
\end{array}$ & $\begin{array}{c}\text { Cerebralvasc. } \\
\text { Diseases }\end{array}$ & \multirow[t]{2}{*}{$\begin{array}{c}\text { Respiratory } \\
\text { Diseases }\end{array}$} & \multirow[t]{2}{*}{$\begin{array}{l}\text { Digestive } \\
\text { Diseases }\end{array}$} & \multirow[t]{2}{*}{$\mathrm{MSCT}^{\mathrm{a}}$} & \multirow[t]{2}{*}{$\begin{array}{c}\text { Multi- } \\
\text { morbidity }\end{array}$} \\
\hline Age & $<50 \mathrm{yrs}$ & & & & & & \\
\hline & $51-55 \mathrm{yrs}$ & 0.90 & 0.85 & 0.86 & 0.80 & 0.87 & 0.95 \\
\hline & $56-60 \mathrm{yrs}$ & 1.27 & 1.19 & 1.10 & 1.07 & 1.03 & 1.35 \\
\hline & $>60 \mathrm{yrs}$ & 1.09 & 1.12 & 1.05 & 1.14 & 0.68 & 1.26 \\
\hline \multirow[t]{2}{*}{ BMI } & ideal & & & & & & \\
\hline & overweight & 1.12 & 1.01 & 1.04 & 1.18 & 0.92 & 1.16 \\
\hline \multirow[t]{3}{*}{ Education } & high & & & & & & \\
\hline & primary & 1.17 & 1.49 & $1.61 \dagger$ & 1.63 & 1.74 & 1.29 \\
\hline & secondary & 0.98 & 1.10 & 1.19 & 1.12 & 0.83 & 1.06 \\
\hline Current/Last Occupational & white collar & & & & & & \\
\hline Status & blue collar & 1.13 & 1.21 & 1.19 & $1.40 \dagger$ & 1.26 & 1.08 \\
\hline & civil servants & $0.61 *$ & $0.58 * *$ & $0.66 *$ & 0.69 & 0.72 & $0.67 \dagger$ \\
\hline & self-employed & $1.50 *$ & $1.75 * *$ & $1.81 * *$ & $2.14 * * *$ & 1.22 & $1.73 * *$ \\
\hline Household Net Income & high & & & & & & \\
\hline & low & 1.11 & 0.99 & 1.03 & 0.75 & 1.37 & 0.92 \\
\hline & middle & 1.22 & 1.06 & 1.17 & 1.07 & 1.39 & 1.22 \\
\hline Life Arrangement & married & & & & & & \\
\hline & living with other & 1.37 & 1.02 & 0.82 & 1.14 & 1.03 & 1.11 \\
\hline & living alone & 1.12 & 1.52 & 1.25 & 1.19 & 0.86 & 1.35 \\
\hline Number of Friends & many & & & & & & \\
\hline & none/few & 1.21 & 1.11 & 1.00 & 1.10 & 1.10 & 1.17 \\
\hline Typ A (Jenkins) & weak & & & & & & \\
\hline & strong & $0.72 *$ & $0.73 *$ & $0.80 \dagger$ & $0.73 *$ & $0.69 \dagger$ & $0.69 * *$ \\
\hline Alcohol Consumption & no & & & & & & \\
\hline & yes & 0.82 & 0.89 & 0.89 & 0.92 & 0.80 & 0.81 \\
\hline Sport Activity & yes & & & & & & \\
\hline & no & 1.01 & 1.09 & 1.17 & 1.08 & 1.01 & 1.13 \\
\hline Health Consciousness & strong & & & & & & \\
\hline & weak & 0.96 & 0.92 & 0.88 & 0.85 & 1.09 & 0.92 \\
\hline Life Satisfaction & satisfied & & & & & & \\
\hline & unsatisfied & $1.52 *$ & $1.42 *$ & $1.45 *$ & $2.17^{* * *}$ & $1.71 \dagger$ & $1.66 *$ \\
\hline Ever unemployed & no & & & & & & \\
\hline & yes & 0.94 & 0.90 & 0.99 & 1.13 & 0.83 & 1.10 \\
\hline Reproductive History & none & & & & & & \\
\hline & $1 \mid$ before age 30 & 0.95 & 0.84 & 0.80 & $0.54 *$ & 0.81 & 0.85 \\
\hline & $1 \mid$ after age 30 & 0.92 & 0.94 & 0.95 & 0.84 & 0.96 & 0.94 \\
\hline & $2 \mid$ before age 28 & 1.09 & 1.11 & 0.98 & 0.90 & 1.06 & 1.22 \\
\hline & $2 \mid$ after age 28 & 0.76 & 0.77 & 0.71 & $0.64 \dagger$ & 0.74 & 0.76 \\
\hline & $3+\mid$ before age 26 & 1.46 & 1.40 & 1.37 & 1.04 & 1.34 & 1.51 \\
\hline & $3+\mid$ after age 26 & 0.97 & 0.90 & 0.83 & 0.81 & 0.69 & 0.94 \\
\hline Smoking Status & Smoking Years (Former) & 1.01 & 1.00 & 1.00 & 1.01 & $1.02 \dagger$ & 1.01 \\
\hline & Smoking Years (Current) & $1.02 * * *$ & $1.01 * *$ & $1.01 * *$ & $1.01 \dagger$ & $1.01 \dagger$ & $1.02 * * *$ \\
\hline Migration History & never migrated & & & & & & \\
\hline & since $10 \mathrm{yrs}$ & 0.82 & 0.82 & 0.89 & 0.83 & $0.55 \dagger$ & 0.78 \\
\hline & since $20 \mathrm{yrs}$ & $1.42 \dagger$ & $1.34 \dagger$ & $1.44 *$ & $1.47 \dagger$ & 1.21 & $1.49 *$ \\
\hline & since $30 \mathrm{yrs}$ & 0.82 & 1.00 & 0.97 & 1.01 & 0.70 & 0.92 \\
\hline & more than $30 \mathrm{yrs}$ & 0.84 & 0.88 & 0.92 & 0.85 & $0.57 *$ & 0.84 \\
\hline General Health Status & good & & & & & & \\
\hline & bad & 1.15 & 1.01 & 1.01 & 0.99 & 1.13 & 1.16 \\
\hline Heart Diseases & absence & & & & & & \\
\hline & presence & & 1.17 & 1.10 & 0.99 & 1.26 & - \\
\hline Cerebralvascular Diseases & absence & & & & & & \\
\hline & presence & 0.57 & & 0.80 & 0.70 & 0.81 & - \\
\hline Hypertension & absence & & & & & & \\
\hline & presence & 0.96 & 0.91 & 0.94 & 0.81 & $0.66 \dagger$ & 0.88 \\
\hline Other Diseases of & absence & & & & & & \\
\hline Circulatory System & presence & $1.36 *$ & 1.21 & $1.24 \dagger$ & $1.33 \dagger$ & 1.33 & $1.28 \dagger$ \\
\hline Diseases of Respiratory & absence & & & & & & \\
\hline System & presence & 0.96 & 1.05 & & 0.95 & 0.61 & - \\
\hline Endocrine,Nutritional \& & absence & & & & & & \\
\hline Metabolic Diseases & presence & 0.89 & 0.95 & 0.96 & 0.94 & 1.11 & 0.90 \\
\hline Diseases of Digestive & absence & & & & & & \\
\hline System & presence & 0.98 & 1.05 & 1.00 & & 1.09 & - \\
\hline Diseases of Musculoskeletal & 1 absence & & & & & & \\
\hline System and Connective & presence & 1.03 & 1.10 & 1.02 & 1.1 & & 1.08 \\
\hline Diseases of the & absence & & & & & & \\
\hline Genitourinary System & presence & $0.75 \dagger$ & 0.87 & 0.83 & $0.65 *$ & 0.71 & $0.74 \dagger$ \\
\hline & $\mathbf{N}$ & 1605 & 1876 & 1722 & 1258 & 884 & 1605 \\
\hline & df & 123 & 123 & 123 & 123 & 123 & 114 \\
\hline & $-2 \operatorname{lnL}$ & -1838 & -2073 & -1884 & -1376 & -1059 & -1943 \\
\hline & Pseudo- $\mathrm{R}^{2}$ & 0.092 & 0.086 & 0.081 & 0.104 & 0.108 & 0.083 \\
\hline
\end{tabular}

$\dagger \mathrm{p}<0.1, * \mathrm{p}<0.05, * * \mathrm{p}<0.01, * * \mathrm{p}<0.00$

${ }^{\mathrm{a}}$ Diseases of Muscoloskeletal System and Connective Tissue 
Table 20: Results of multinomial logistic regression for transition from the absence to the presence of specific diseases, males, western Germany

\begin{tabular}{|c|c|c|c|c|c|c|c|}
\hline \multicolumn{2}{|c|}{ Covariates } & $\begin{array}{c}\text { Heart } \\
\text { Diseases }\end{array}$ & $\begin{array}{l}\text { Cerebralvasc. } \\
\text { Diseases }\end{array}$ & \multirow[t]{2}{*}{$\begin{array}{l}\text { Respiratory } \\
\text { Diseases }\end{array}$} & \multirow[t]{2}{*}{$\begin{array}{l}\text { Digestive } \\
\text { Diseases }\end{array}$} & \multirow[t]{2}{*}{ MSCT $^{a}$} & \multirow[t]{2}{*}{$\begin{array}{c}\text { Multi- } \\
\text { morbidity }\end{array}$} \\
\hline Age & $<50 \mathrm{yrs}$ & & & & & & \\
\hline & $51-55 \mathrm{yrs}$ & 1.40 & 1.03 & $1.92 \dagger$ & 1.41 & 1.10 & $1.81 *$ \\
\hline & $56-60 \mathrm{yrs}$ & 1.35 & 1.00 & 1.13 & 1.12 & 0.73 & $1.86 *$ \\
\hline & $>60 \mathrm{yrs}$ & 1.18 & 1.63 & 1.26 & 1.49 & 0.72 & $2.54 * *$ \\
\hline \multirow[t]{2}{*}{ BMI } & ideal & & & & & & \\
\hline & overweight & $1.72 *$ & 1.42 & $1.69 \dagger$ & 1.48 & 1.39 & $1.50 *$ \\
\hline \multirow[t]{3}{*}{ Education } & high & & & & & & \\
\hline & primary & $0.25 *$ & 0.96 & 0.72 & 0.20 & 1.26 & 0.50 \\
\hline & secondary & 0.82 & 1.14 & 1.30 & 0.90 & 0.77 & 0.84 \\
\hline Current/Last Occupational & white collar & & & & & & \\
\hline Status & blue collar & 0.92 & 1.15 & 0.83 & 1.01 & 1.26 & $0.57 *$ \\
\hline & civil servants & 1.50 & 0.82 & 0.86 & 1.17 & 1.11 & 1.16 \\
\hline & self-employed & 1.22 & 1.63 & 1.15 & 1.81 & 1.61 & 1.20 \\
\hline Household Net Income & high & & & & & & \\
\hline & low & $2.19^{* *}$ & 1.12 & $2.22 *$ & 1.46 & $2.96 * *$ & 1.18 \\
\hline & middle & 1.22 & 0.83 & 1.55 & 1.22 & 1.55 & 1.28 \\
\hline Life Arrangement & married & & & & & & \\
\hline & living with other & $2.24 \dagger$ & 0.50 & 1.06 & 1.39 & 0.27 & 1.73 \\
\hline & living alone & 0.68 & 1.75 & 0.84 & 1.78 & 0.39 & 0.84 \\
\hline Number of Friends & many & & & & & & \\
\hline & none/few & 1.17 & 1.27 & 1.11 & $1.62 \dagger$ & 1.15 & $1.40 \dagger$ \\
\hline Typ A (Jenkins) & weak & & & & & & \\
\hline & strong & 0.80 & 0.94 & 0.94 & 0.91 & 1.04 & $0.66 *$ \\
\hline Alcohol Consumption & no & & & & & & \\
\hline & yes & 1.05 & 0.70 & 1.03 & 0.73 & 0.86 & 0.89 \\
\hline Sport Activity & yes & & & & & & \\
\hline & no & 1.08 & 1.41 & $1.64 \dagger$ & 1.21 & 1.35 & 1.33 \\
\hline Health Consciousness & strong & & & & & & \\
\hline & weak & 0.95 & 1.12 & 1.13 & 1.20 & 1.10 & 0.91 \\
\hline Life Satisfaction & satisfied & & & & & & \\
\hline & unsatisfied & 1.24 & 1.22 & 0.86 & 0.81 & 1.03 & 1.13 \\
\hline Ever unemployed & no & & & & & & \\
\hline & yes & 1.40 & 1.09 & 1.12 & $2.36^{* *}$ & 1.11 & $1.88^{* *}$ \\
\hline Reproductive History & none & & & & & & \\
\hline & $1 \mid$ before age 30 & 0.50 & $0.22 *$ & 0.74 & 0.71 & 1.17 & $0.42 *$ \\
\hline & $1 \mid$ after age 30 & 1.02 & 0.85 & 0.77 & 0.82 & 1.34 & 0.89 \\
\hline & $2 \mid$ before age 28 & 0.73 & 0.91 & 0.65 & 0.64 & 1.09 & 0.93 \\
\hline & $2 \mid$ after age 28 & $0.50 \dagger$ & 0.85 & 0.68 & 0.59 & 1.06 & 0.72 \\
\hline & $3+\mid$ before age 26 & 0.79 & 0.79 & 0.92 & 0.42 & 1.55 & 0.90 \\
\hline & $3+\mid$ after age 26 & 1.01 & 0.65 & 0.95 & 1.27 & 0.74 & 1.04 \\
\hline Smoking Status & Smoking Years (Former) & $1.02 *$ & 1.01 & $1.02 \dagger$ & $1.02 \dagger$ & 1.01 & 1.01 \\
\hline & Smoking Years (Current) & $1.01 \dagger$ & 1.01 & 1.00 & 1.00 & 0.99 & 1.00 \\
\hline Migration History & never migrated & & & & & & \\
\hline & since $10 \mathrm{yrs}$ & 1.16 & 1.01 & 1.30 & 0.99 & 0.70 & 0.99 \\
\hline & since $20 \mathrm{yrs}$ & 1.33 & 0.97 & 1.23 & 0.91 & 1.18 & 1.44 \\
\hline & since $30 \mathrm{yrs}$ & 0.87 & 0.79 & 0.81 & 0.69 & 0.62 & 0.75 \\
\hline & more than $30 \mathrm{yrs}$ & 1.03 & 0.84 & 1.32 & 0.66 & $0.55 \dagger$ & 0.75 \\
\hline General Health Status & good & & & & & & \\
\hline & bad & 1.29 & 1.07 & 0.77 & 1.16 & 1.35 & $1.80 * *$ \\
\hline Heart Diseases & absence & & & & & & \\
\hline & presence & & $1.70 \dagger$ & 1.43 & $1.79 \dagger$ & 1.44 & - \\
\hline Cerebralvascular Diseases & absence & & & & & & \\
\hline & presence & 1.34 & & 0.97 & 1.32 & 0.46 & - \\
\hline Hypertension & absence & & & & & & \\
\hline & presence & 1.13 & 0.84 & 0.64 & 1.08 & 0.83 & 0.98 \\
\hline Other Diseases of & absence & & & & & & \\
\hline Circulatory System & presence & 1.21 & 1.10 & 0.90 & 0.95 & 1.19 & 0.96 \\
\hline Diseases of Respiratory & absence & & & & & & \\
\hline System & presence & 1.06 & 1.06 & & 1.18 & 0.77 & - \\
\hline Endocrine,Nutritional \& & absence & & & & & & \\
\hline Metabolic Diseases & presence & 1.16 & $1.52 \dagger$ & $1.57 \dagger$ & 0.98 & 1.33 & 1.13 \\
\hline Diseases of Digestive & absence & & & & & & \\
\hline System & presence & $1.64 *$ & $1.70 *$ & 1.52 & & $1.58 \dagger$ & - \\
\hline Diseases of Musculoskeletal & 1 absence & & & & & & \\
\hline System and Connective & presence & 0.75 & 0.90 & 1.35 & 1.13 & & 1.13 \\
\hline Diseases of the & absence & & & & & & \\
\hline Genitourinary System & presence & 0.97 & 0.82 & 1.14 & 0.86 & 1.37 & 0.91 \\
\hline & $\mathbf{N}$ & 1454 & 1666 & 1678 & 952 & 826 & 1605 \\
\hline & df & 123 & 123 & 123 & 123 & 123 & 114 \\
\hline & $-2 \operatorname{lnL}$ & -1497 & -1655 & -1607 & -964 & -887 & -1943 \\
\hline & Pseudo- $R^{2}$ & 0.087 & 0.084 & 0.087 & 0.116 & 0.122 & 0.083 \\
\hline
\end{tabular}

$\dagger \mathrm{p}<0.1,{ }^{*} \mathrm{p}<0.05, * * \mathrm{p}<0.01,{ }^{* * *} \mathrm{p}<0.00$

${ }^{\mathrm{a}}$ Diseases of Muscoloskeletal System and Connective Tissue 


\subsection{Transitions in general health in eastern Germany}

Because of the low case numbers it was only possible to analyse the one-way health transition from bad general health at baseline to the reported status of general health at follow-up for the eastern German LES sample. Table 21 presents the changes in general health for eastern German females. The risk of remaining in bad general health was only associated with the earlier presence of hypertension. The risk of dying was higher for the oldest age group and for females with secondary education. Sports inactivity and dissatisfaction with life also increased the likelihood of dying between the two surveys, but the association did not reach the five per cent significance level. On the other hand, women living alone, those with low health consciousness and those reporting the presence of diseases of the genitourinary system at baseline had a lower risk of dying at the 10 per cent significance level. The risk of getting lost for the follow-up wave was higher for females with secondary education, low net household income and those with limited social contacts. Sports inactivity was also found to raise the risk of attrition, but at the 10 per cent significance level only.

The changes in general health among males can be found in Table 22. The middle net household income and the earlier presence of circulatory diseases reduced the likelihood of moving to good general health between the surveys. In contrast, a migration background increased the risk. But the effects were only significant at the 10 per cent confidence level. The risk of dying was significantly higher for sports-inactive men as well as for former and current smokers. Compared to females, the highest age group of males was also associated with higher odds of dying at the 10 per cent significance level. A lower mortality risk was found for males who lived alone and for males with migration background. Low net household income and sports inactivity increased the likelihood of loss, however, without reaching the five per cent significance level.

\subsection{Transitions in disease status in eastern Germany}

The analysis of the onset of specific diseases in the period between the two surveys follows the same procedure as described for the western German sample. Thus, the results of multinomial regression consider only the transition from the absence of specific diseases at baseline to their presence, death or attrition at follow-up. Table 23 gives the corresponding transitions to death for females. A higher risk of dying between the LES waves was associated with age and the presence of endocrine, nutritional and metabolic diseases at baseline. Increasing age was also associated with a higher likelihood of loss, as well as secondary education and low net household income (Table 24). A lower risk of attrition was found for females who lived alone at the time of the first survey. The changes in disease statuses are presented in Table 25. The presence of diseases of the genitourinary system at baseline increased the odds of developing circulatory diseases during the follow-up period. No effects could be found for the transition from absence to presence of diseases of the digestive system. The likelihood of diseases of the musculoskeletal system and connective tissue was higher for females who were unsatisfied with their life and those who had had one child earlier in life. 
Furthermore, former or current smoking increased the risk of developing diseases of the musculoskeletal system and connective tissue by five per cent per additional smoking year.

Table 26 gives the transition to death for males. The risk of dying increased with age, as well as for those being inactive in sports and smokers at baseline. On the other hand, a migration background reduced the risk of dying. The risk of loss was higher for the oldest age groups, for males with limited social contacts, for males who were unsatisfied with their life and for those who had suffered from diseases of the digestive system at the time of the first survey (Table 27). A lower likelihood of attrition was found for males with a migration background. The transitions from the absence to the presence of specific diseases can be found in Table 28. The risk of developing circulatory diseases was higher for the middle age group and for males with a limited number of social contacts. Secondary education, sports inactivity and former smoking were associated with a higher likelihood of the presence of digestive diseases at the time of the second survey. The risk of developing diseases of the musculoskeletal system and connective tissue was higher for cases with the presence of diseases of the digestive system at baseline. 
Table 21: Results of multinomial logistic regression for transitions of general health, females, eastern Germany

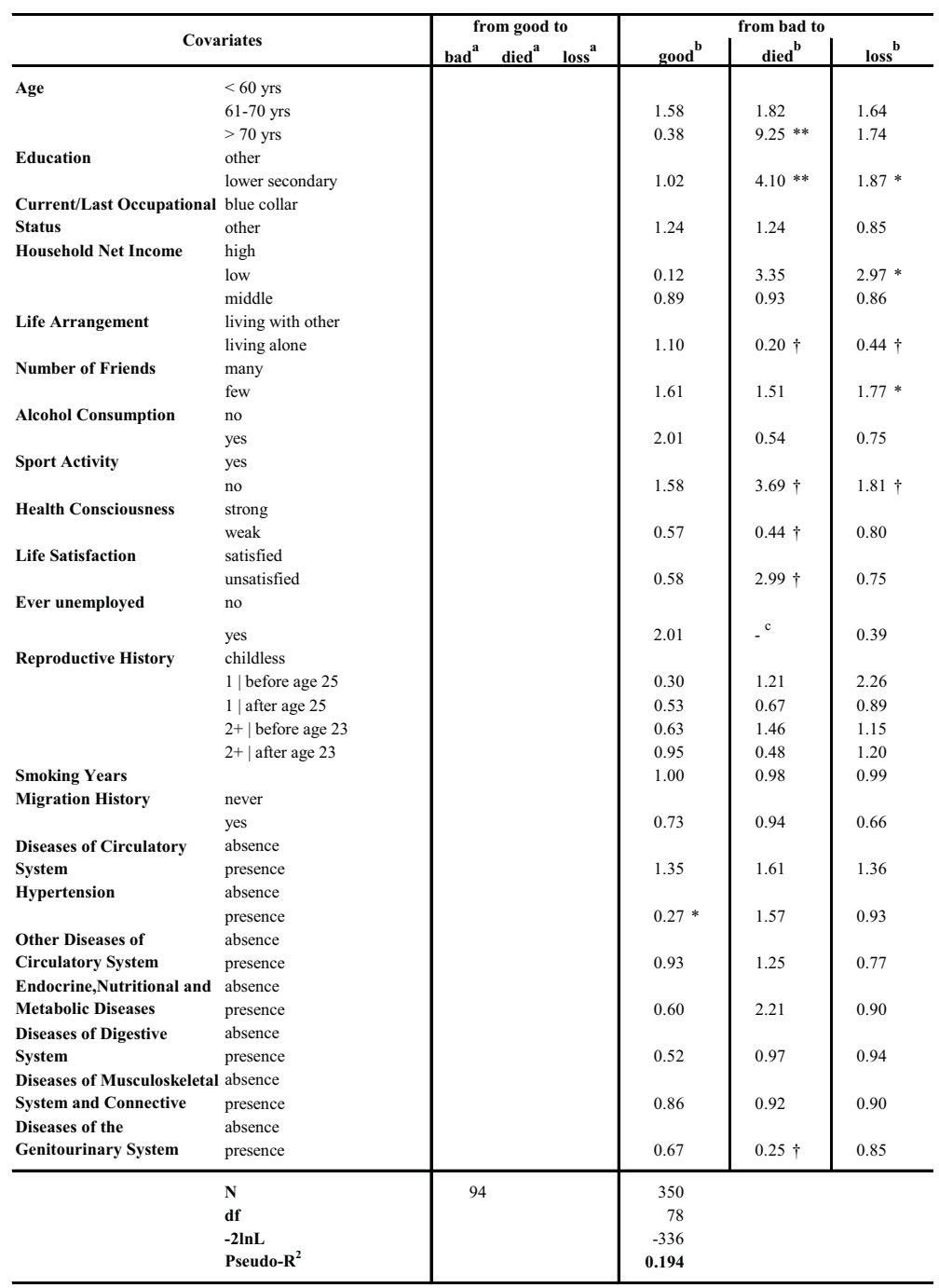

$\dagger \mathrm{p}<0.1, * \mathrm{p}<0.05, * * \mathrm{p}<0.01, * * * \mathrm{p}<0.001$

a vs. good health status

${ }^{b}$ vs. bad health status

${ }^{c}$ no cases 
Table 22: Results of multinomial logistic regression for transitions in general health, males, eastern Germany

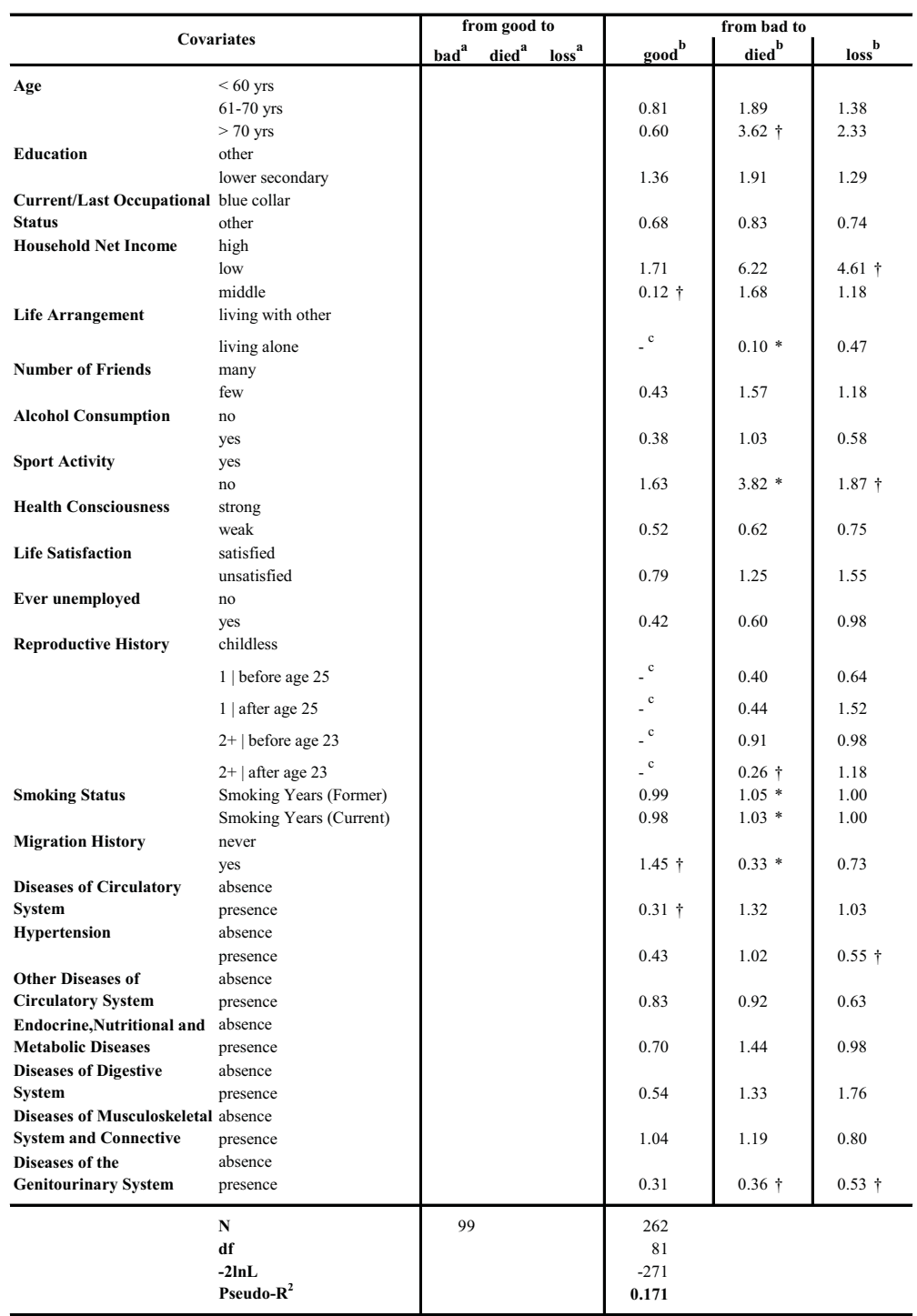

$\dagger \mathrm{p}<0.1, * \mathrm{p}<0.05,{ }^{* *} \mathrm{p}<0.01,{ }^{* * *} \mathrm{p}<0.001$

${ }^{a}$ vs. good health status

${ }^{b}$ vs. bad health status

${ }^{c}$ no cases 
Table 23: Results of multinomial logistic regression for the transition from the absence of specific diseases to death, females, eastern Germany

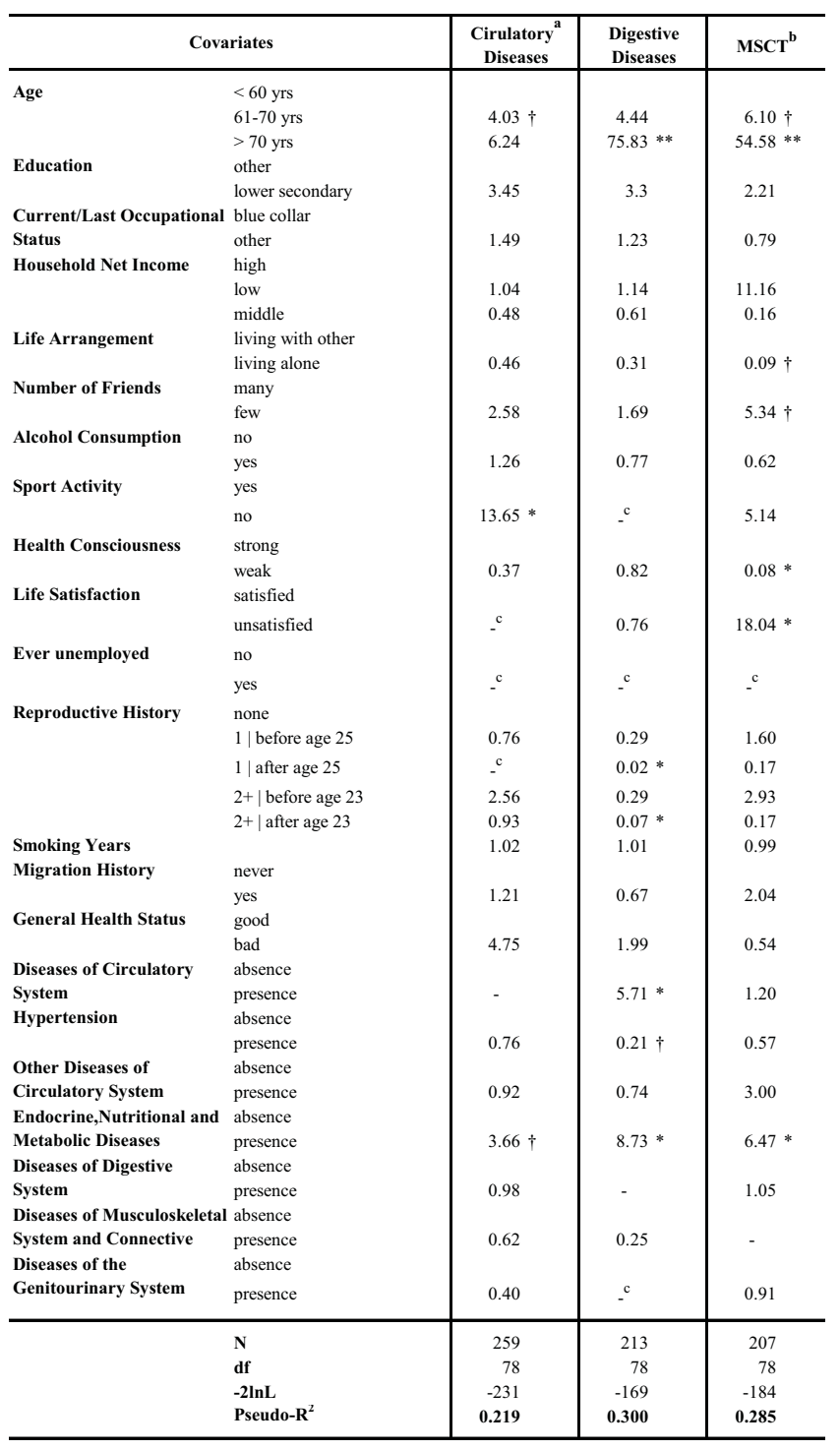

$\dagger \mathrm{p}<0.1,{ }^{*} \mathrm{p}<0.05, * * \mathrm{p}<0.01, * * * \mathrm{p}<0.001$

${ }^{\mathrm{a}}$ Heart Diseases and Cerebralvascular Diseases

${ }^{\mathrm{b}}$ Diseases of Muscoloskeletal System and Connective Tissue

${ }^{c}$ no cases 
Table 24: Results of multinomial logistic regression for the transition from the absence of specific diseases to attrition, females, eastern Germany

\begin{tabular}{|c|c|c|c|c|}
\hline \multicolumn{2}{|c|}{ Covariates } & $\begin{array}{c}\text { Cirulatory }^{\mathrm{a}} \\
\text { Diseases }\end{array}$ & $\begin{array}{c}\text { Digestive } \\
\text { Diseases }\end{array}$ & \multirow[t]{2}{*}{ MSCT $^{b}$} \\
\hline Age & $<60 \mathrm{yrs}$ & & & \\
\hline & $61-70 \mathrm{yrs}$ & $2.26 *$ & $2.19 \dagger$ & 2.00 \\
\hline & $>70 \mathrm{yrs}$ & 2.04 & $4.47 *$ & $3.32 \dagger$ \\
\hline \multirow[t]{2}{*}{ Education } & other & & & \\
\hline & lower secondary & $3.66 * * *$ & $2.37 *$ & $2.24 \dagger$ \\
\hline \multicolumn{5}{|c|}{ Current/Last Occupational blue collar } \\
\hline Status & other & 0.95 & 0.58 & 0.97 \\
\hline \multirow[t]{3}{*}{ Household Net Income } & high & & & \\
\hline & low & $3.45 \dagger$ & $7.93 * *$ & $8.44 *$ \\
\hline & middle & 0.74 & 1.26 & 1.55 \\
\hline \multirow{2}{*}{ Life Arrangement } & living with other & & & \\
\hline & living alone & 0.41 & $0.17 *$ & $0.17 *$ \\
\hline \multirow[t]{2}{*}{ Number of Friends } & many & & & \\
\hline & few & 1.46 & 1.52 & $1.98 \dagger$ \\
\hline \multirow[t]{2}{*}{ Alcohol Consumption } & no & & & \\
\hline & yes & $0.32 * *$ & 0.71 & 0.58 \\
\hline \multirow[t]{2}{*}{ Sport Activity } & yes & & & \\
\hline & no & 1.87 & 1.57 & 0.73 \\
\hline \multirow[t]{2}{*}{ Health Consciousness } & strong & & & \\
\hline & weak & 1.07 & 0.76 & 1.41 \\
\hline \multirow[t]{2}{*}{ Life Satisfaction } & satisfied & & & \\
\hline & unsatisfied & 0.61 & 0.95 & 0.78 \\
\hline \multirow[t]{2}{*}{ Ever unemployed } & no & & & \\
\hline & yes & 0.58 & $0.09 * *$ & 0.59 \\
\hline \multirow[t]{5}{*}{ Reproductive History } & none & & & \\
\hline & $1 \mid$ before age 25 & 0.60 & $0.14 *$ & 1.08 \\
\hline & $1 \mid$ after age 25 & 0.55 & $0.22 \dagger$ & 1.23 \\
\hline & $2+\mid$ before age 23 & 0.75 & 0.32 & 0.46 \\
\hline & $2+\mid$ after age 23 & 0.83 & $0.27 \dagger$ & 0.86 \\
\hline Smoking Years & & 1.01 & 1.01 & 1.03 \\
\hline \multirow[t]{2}{*}{ Migration History } & never & & & \\
\hline & yes & 1.05 & 1.40 & 0.60 \\
\hline \multirow[t]{2}{*}{ General Health Status } & good & & & \\
\hline & bad & 0.99 & 0.82 & 1.04 \\
\hline Diseases of Circulatory & absence & & & \\
\hline System & presence & - & 0.88 & 0.66 \\
\hline \multirow[t]{2}{*}{ Hypertension } & absence & & & \\
\hline & presence & 0.84 & 1.06 & 0.84 \\
\hline Other Diseases of & absence & & & \\
\hline Circulatory System & presence & 0.85 & 0.90 & 1.01 \\
\hline Endocrine,Nutritional and & absence & & & \\
\hline Metabolic Diseases & presence & 1.17 & 0.99 & 1.69 \\
\hline Diseases of Digestive & absence & & & \\
\hline System & presence & 0.81 & - & 1.39 \\
\hline \multicolumn{5}{|c|}{ Diseases of Musculoskeletal absence } \\
\hline System and Connective & presence & 0.61 & 0.99 & - \\
\hline Diseases of the & absence & & & \\
\hline \multirow[t]{5}{*}{ Genitourinary System } & presence & 0.92 & 1.35 & 0.98 \\
\hline & $\mathbf{N}$ & 259 & 213 & 207 \\
\hline & df & 78 & 78 & 78 \\
\hline & $-2 \ln L$ & -231 & -169 & -184 \\
\hline & Pseudo-R ${ }^{2}$ & 0.219 & 0.300 & 0.285 \\
\hline
\end{tabular}

$\dagger \mathrm{p}<0.1,{ }^{*} \mathrm{p}<0.05, * * \mathrm{p}<0.01, * * * \mathrm{p}<0.001$

${ }^{\mathrm{a}}$ Heart Diseases and Cerebralvascular Diseases

${ }^{b}$ Diseases of Muscoloskeletal System and Connective Tissue 
Table 25: Results of multinomial logistic regression for the transition from the absence to the presence of specific diseases, females, eastern Germany

\begin{tabular}{|c|c|c|c|c|}
\hline \multicolumn{2}{|c|}{ Covariates } & $\begin{array}{c}\text { Cirulatory }^{\mathrm{a}} \\
\text { Diseases } \\
\end{array}$ & $\begin{array}{l}\begin{array}{l}\text { Digestive } \\
\text { Diseases }\end{array} \\
\end{array}$ & \multirow[t]{2}{*}{ MSCT $^{\mathrm{b}}$} \\
\hline Age & $<60 \mathrm{yrs}$ & & & \\
\hline & $61-70 \mathrm{yrs}$ & 1.27 & 0.63 & 0.91 \\
\hline & $>70 \mathrm{yrs}$ & 3.03 & 1.39 & 1.31 \\
\hline \multirow[t]{2}{*}{ Education } & other & & & \\
\hline & lower secondary & 0.55 & 2.11 & 0.31 \\
\hline \multicolumn{5}{|c|}{ Current/Last Occupational blue collar } \\
\hline Status & other & 0.87 & 1.52 & 0.77 \\
\hline \multirow[t]{3}{*}{ Household Net Income } & high & & & \\
\hline & low & 0.48 & 1.15 & 2.46 \\
\hline & middle & 0.44 & 1.08 & 1.61 \\
\hline \multirow[t]{2}{*}{ Life Arrangement } & living with other & & & \\
\hline & living alone & 1.72 & 0.13 & 0.46 \\
\hline \multirow[t]{2}{*}{ Number of Friends } & many & & & \\
\hline & few & 1.24 & 1.78 & 2.42 \\
\hline \multirow[t]{2}{*}{ Alcohol Consumption } & no & & & \\
\hline & yes & 0.65 & 0.77 & 0.63 \\
\hline \multirow[t]{2}{*}{ Sport Activity } & yes & & & \\
\hline & no & 1.42 & 1.16 & $0.31 *$ \\
\hline \multirow[t]{2}{*}{ Health Consciousness } & strong & & & \\
\hline & weak & 0.69 & 1.44 & 1.92 \\
\hline \multirow[t]{2}{*}{ Life Satisfaction } & satisfied & & & \\
\hline & unsatisfied & 1.27 & 2.77 & $4.88 *$ \\
\hline \multirow[t]{2}{*}{ Ever unemployed } & no & & & \\
\hline & yes & 0.89 & 1.97 & 2.00 \\
\hline \multirow[t]{5}{*}{ Reproductive History } & none & & & \\
\hline & $1 \mid$ before age 25 & 2.60 & 0.13 & $11.30 *$ \\
\hline & $1 \mid$ after age 25 & 1.56 & $\therefore$ & 1.90 \\
\hline & $2+\mid$ before age 23 & 1.64 & 0.44 & 3.40 \\
\hline & $2+\mid$ after age 23 & 1.13 & 0.43 & 1.58 \\
\hline Smoking Years & & 1.01 & 1.01 & $1.05 *$ \\
\hline \multirow[t]{2}{*}{ Migration History } & never & & & \\
\hline & yes & 2.03 & 1.86 & $3.55 \dagger$ \\
\hline \multirow[t]{2}{*}{ General Health Status } & good & & & \\
\hline & bad & 2.59 & 2.00 & 0.97 \\
\hline Diseases of Circulatory & absence & & & \\
\hline System & presence & - & 1.79 & 0.81 \\
\hline \multirow[t]{2}{*}{ Hypertension } & absence & & & \\
\hline & presence & 1.34 & 1.34 & 0.82 \\
\hline Other Diseases of & absence & & & \\
\hline Circulatory System & presence & 0.88 & 3.02 & 1.02 \\
\hline Endocrine,Nutritional and & absence & & & \\
\hline Metabolic Diseases & presence & 1.66 & 2.49 & $2.76 \dagger$ \\
\hline Diseases of Digestive & absence & & & \\
\hline System & presence & 0.98 & - & 1.56 \\
\hline \multicolumn{2}{|c|}{ Diseases of Musculoskeletal absence } & & & \\
\hline System and Connective & presence & 0.63 & 0.28 & - \\
\hline Diseases of the & absence & & & \\
\hline \multirow[t]{5}{*}{ Genitourinary System } & presence & $5.70^{* *}$ & 2.40 & 1.47 \\
\hline & $\mathbf{N}$ & 259 & 213 & 207 \\
\hline & df & 78 & 78 & 78 \\
\hline & $-2 \ln \mathbf{L}$ & -231 & -169 & -184 \\
\hline & Pseudo- $^{2}$ & 0.219 & 0.300 & 0.285 \\
\hline
\end{tabular}

$\dagger \mathrm{p}<0.1, * \mathrm{p}<0.05, * * \mathrm{p}<0.01, * * * \mathrm{p}<0.001$

${ }^{\mathrm{a}}$ Heart Diseases and Cerebralvascular Diseases

${ }^{\mathrm{b}}$ Diseases of Muscoloskeletal System and Connective Tissue

${ }^{c}$ no cases 
Table 26: Results of multinomial logistic regression for the transition from the absence of disease to death, males, eastern Germany

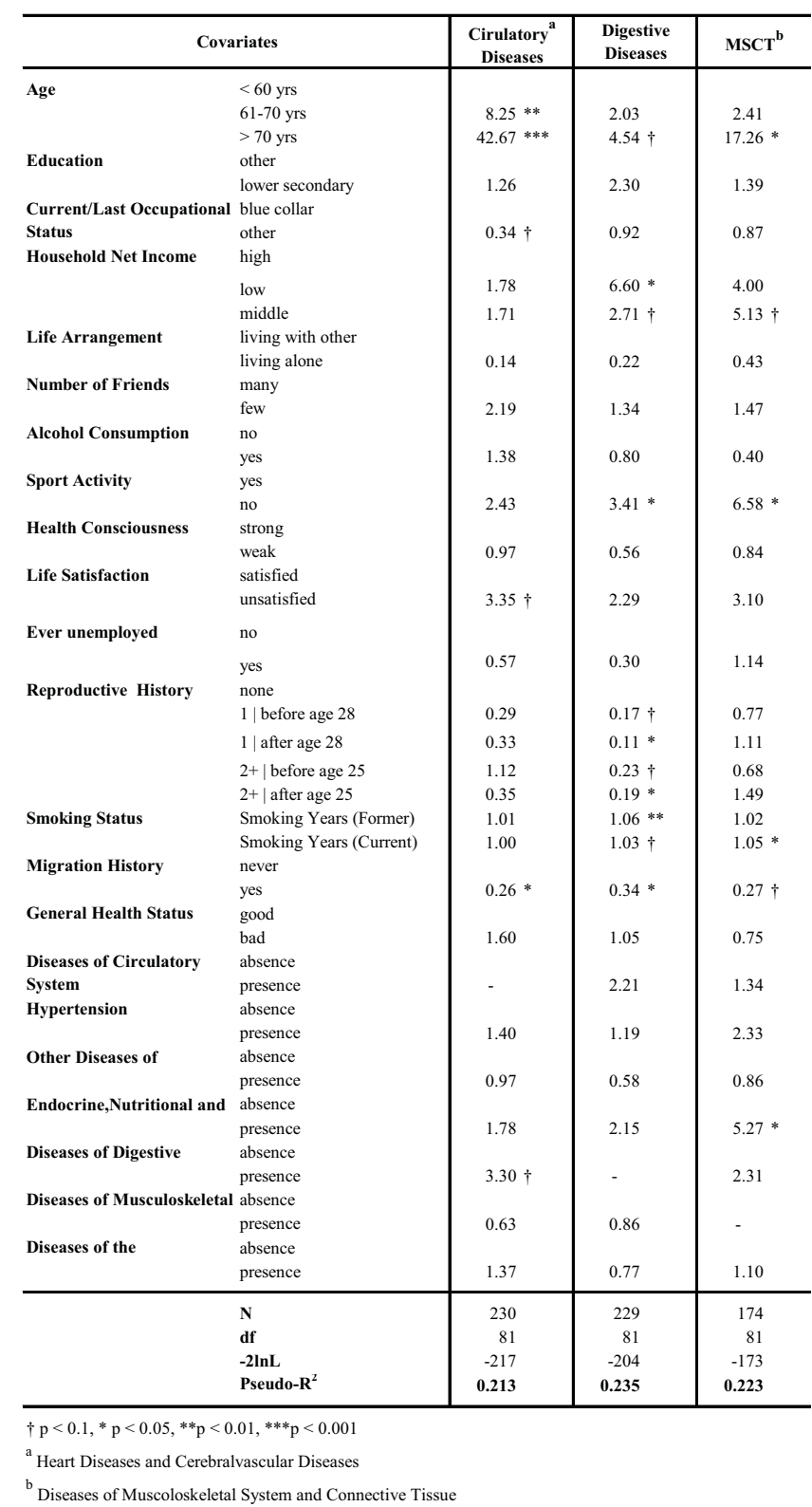


Table 27: Results of multinomial logistic regression for the transition from the absence of specific diseases to attrition, males, eastern Germany

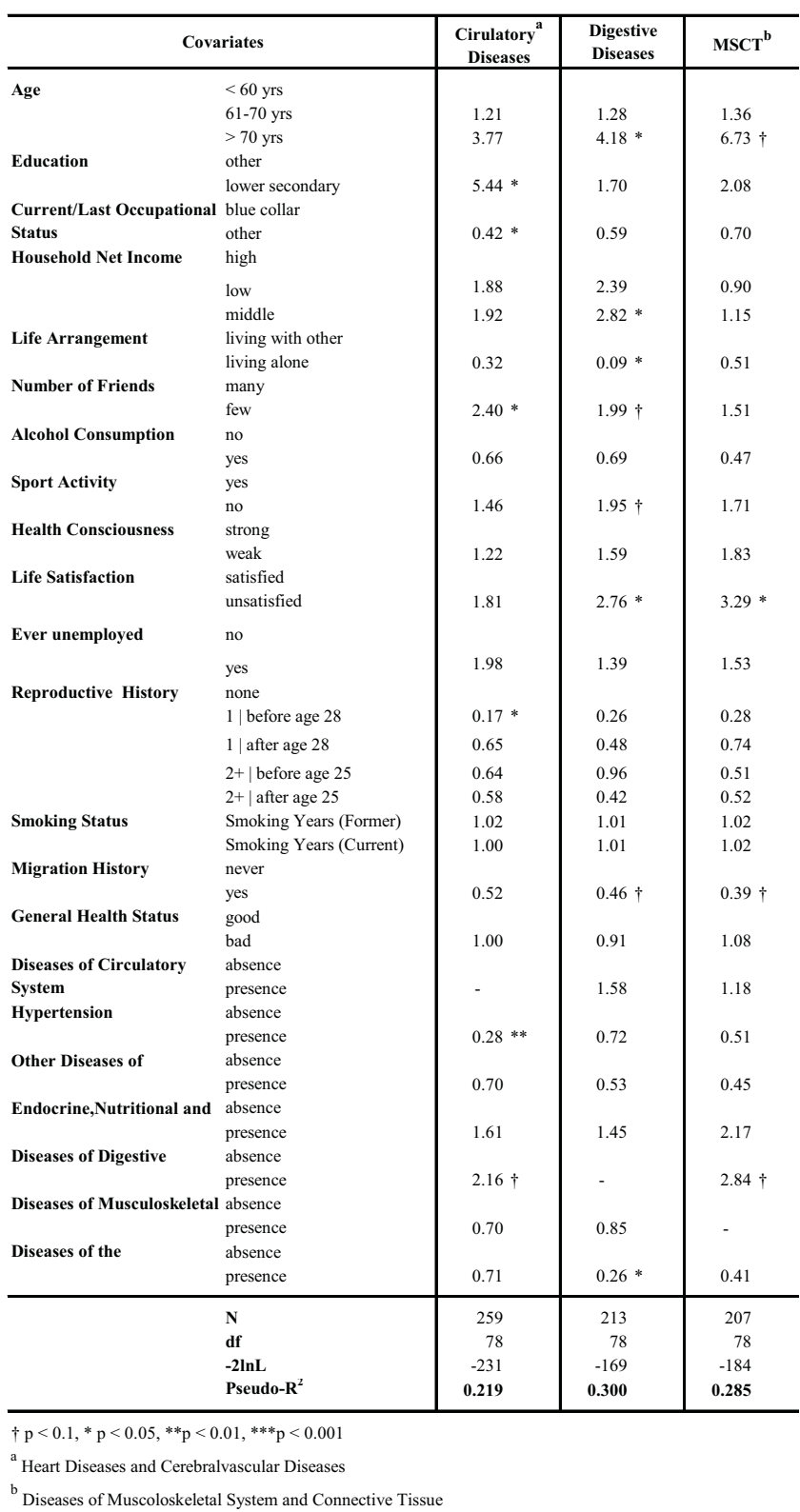


Table 28: Results of multinomial logistic regression for the transition from the absence to the presence of specific diseases, males, eastern Germany

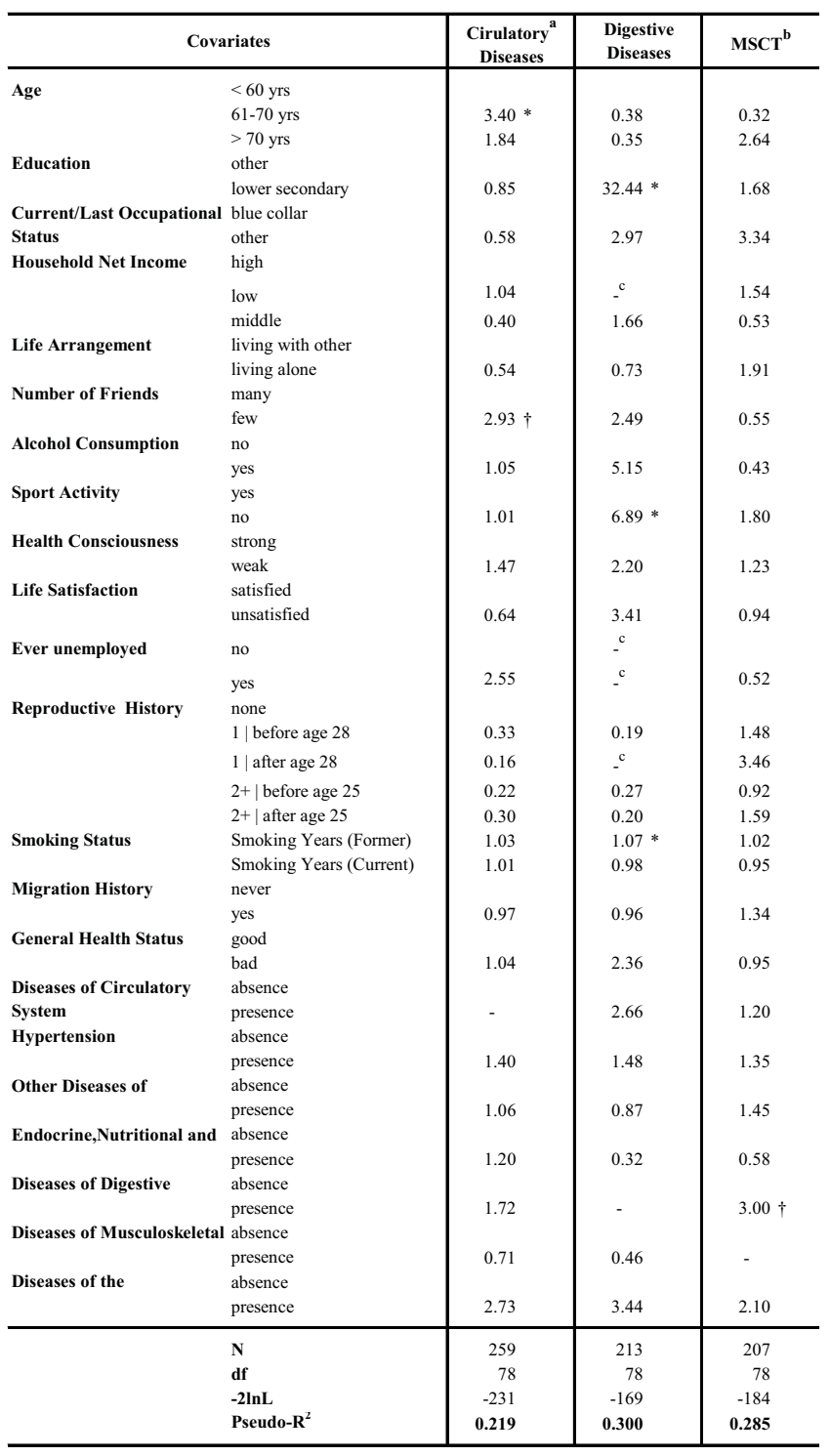

$\dagger \mathrm{p}<0.1, * \mathrm{p}<0.05, * * \mathrm{p}<0.01, * * * \mathrm{p}<0.001$

${ }^{\mathrm{a}}$ Heart Diseases and Cerebralvascular Diseases

${ }^{\mathrm{b}}$ Diseases of Muscoloskeletal System and Connective Tissue

${ }^{c}$ no cases 


\section{Discussion}

The specific characteristics of the LES to offer extensive data on health conditions and health determinants in a longitudinal setting and for two sub-populations which mainly lived in an eastern respective western European society make this survey unique. However, we have to be aware that the LES and the corresponding analysis contain several limitations which should be kept in mind when interpreting the main results of this study.

First, the information about the general health and the presence or absence of specific diseases stem from self-reports of the respondents. On the one hand, self-rated health is known to provide reliable information about a person's experience with illness, disabilities and health behaviour (Manderbacka 1998; Simon et al. 2005). On the other hand, the correctness of the information regarding the prevalence of diseases can be seen with some scepticism. Our analysis which was based on these self-reports revealed indeed the well-documented association between the prevalence of diseases at baseline and mortality during follow-up. Thus, we think that the information provided by the LES is reliable. Unfortunately, the data did not allow the inclusion of neoplasm because of the low case numbers reported in the LES, although neoplasm is the second most frequent cause of death in Germany. We assume that such irregularities arise because some specific diseases were underreported or substituted by other diseases. For instance, lung cancer could be reported as disease of the respiratory system. Another bias regarding gender differences in the prevalence of diseases was possibly caused by the fact that women had higher rates of physicians' services and hospital care (David \& Kaplan 1995; Mustard et al. 1998; Statistisches Bundesamt 2007b). Thus, it could be that females had better information about the presence of specific diseases than males.

Second, the results of health and disease transitions are not representative for both parts of Germany. The respondents who were lost to follow-up were significantly different from those who were re-interviewed. For both the eastern and western German sample, the females who participated in the second survey were younger, more educated and more likely to have a middle or high net household income than all women included in the first LES wave. Further, the western German female participants of the second wave were more active in sports and more of them had lived at least for 30 years at the same residence. The re-interviewed men from the western sample included more civil servants but less self-employed persons, were more likely to have a strong type A behaviour, were more satisfied with life and to a higher proportion they were non- or ex-smokers. The eastern German males who participated in the second wave were younger, had more friends, were more satisfied with life and had less frequently experienced digestive diseases at the moment of first interview. Therefore, we can conclude that both samples were biased to subjects with higher socioeconomic status and healthier lifestyles.

Third, the comparisons of the results for eastern and western Germany and for women and men suffer from the characteristics of the LES data. Regarding the comparison of eastern and western Germany it is obvious that the different observation times make the two sub- 
samples not directly comparable. In addition, the small size of the eastern German sample made it necessary to reduce the number of categories in the variables education and occupation status. Furthermore, the variables body mass index, type A behaviour, diseases of the respiratory system and multimorbidity could not be analysed at all with the eastern German LES sample. Focusing on a life course perspective required to operate some variables differently for men and women and for eastern and western Germany, as described in Section 2.3.

Besides these limitations, the data offer a variety of interpretable impacts on health. An age effect was of course observable for mortality for both sexes and for both parts of Germany but a general age effect on the onset of bad general health, specific diseases or multimorbidity at baseline could only be explored for western German females, despite an increased risk of loss by age. The higher mortality of western German males resulted in a selective healthier sample without any age effect for the onset of bad general health or the presence of specific diseases after follow-up. The eastern German respondents were older at baseline. Considering the lower life expectancy in East Germany (Luy 2004), the male respondents at baseline were more strongly selected as compared to their western German counterparts, while eastern German females had reached ages at baseline in which mortality starts to increase considerably. This fact explains why only the highest age group of men and all considered age groups of eastern women were associated with higher mortality. The lack of female's onset of diseases could be a result of their higher risk of loss by age and, again, of a selection effect. Our analysis supports also the conjecture that the pathogenesis of disease is not caused by the ageing process alone. Furthermore, the stepwise regression analysis (the results are not shown in this paper but are available from the authors) showed a decline of the age effect when controlling for socioeconomic and lifestyle factors.

Socioeconomic differences in mortality could be found in the western German sample, above all for females. However, an education effect was found for females only, although other studies found a larger effect of educational differences in mortality among men (e.g. Lin et al. 2003). In our study the effect of males' education disappeared after controlling for occupational status and net household income. In line with our results, Klein (1996) found in his analysis of the years 1984-1993 also higher differences in life expectancy between high and low educated for women than for men. The negative influence of low net household income on survival found in the LES was consistent with other studies (Lampert \& Kroll 2006). However, Luy (2005) - using the LES as well but following a different research strategy - could not find differences in mortality by income for all ages. Socioeconomic differences in education and occupational status were measurable for diseases of the digestive system for females in western Germany. This result is consistent with other recent studies which described socioeconomic differences in the presence or at onset of obesity (Kaplan et al. 2003; Sundquist et al. 2004; Sulander \& Uutela 2007). In fact, obesity was the high frequently diseases in our category of diseases of digestive system. Furthermore, western German males with low net household income had a higher risk of presence of heart diseases and diseases of respiratory system and musculoskeletal system and connective tissue at follow-up. Only low educated males in eastern Germany showed a higher risk for the onset of 
diseases of digestive system between the two surveys. Transitions in general health were not associated with socioeconomic factors. However, the baseline analysis revealed strong health effects of education and income in western Germany and income for eastern German females, which was consistent with the findings of other cross-sectional studies (Mielck 1994; Helmert, Mielck \& Shea 1997; Lüschen et al. 1997a; Mielck et al. 2000; Knesebeck et al. 2003). In spite of selection through mortality and attrition, low socioeconomic status leads to cumulative disadvantage in the longitudinal changes in health for both sexes, however. Furthermore, the results presented in this study extent the associations between socioeconomic status and presence of disease by diseases of respiratory system and diseases of musculoskeletal system and connective tissue (Helmert et al. 1989; Rathmann et al. 2005; Hach et al. 2007).

Regarding the analysed life course events we found that experience with unemployment increased the risk of multimorbidity for both sexes in western Germany, but it was not associated with a higher mortality risk. Additionally, diseases of the digestive system were also related to unemployment over life for western German males. The health consequences of unemployment are very different in the eastern German population as a consequence of the employment and social policy in the former GDR (Hoffmann \& Schwartz 2005). Due to the centrally planned economy, unemployment was reduced to low levels and short durations. In fact, recent studies showed that occupational stress and dissatisfaction with occupation were mainly related to variation in health outcome (Kunzendorff 1994; Lüschen, Niemann \& Apelt 1997b). The information about smoking behaviour over life offered that current smoking was related to higher mortality for both sexes in western Germany and for males in eastern Germany. The low proportion of female smokers in eastern Germany (Heinemann, Dinkel \& Görtler 1996) was the reason for the non-existing effect of smoking on mortality among eastern German women. Former smoking was only related to higher mortality for men in western Germany. The mean age of quitting smoking was with 43 years equal for both sexes, but the mean number of smoking years was higher for men than for women with 25 and 20 years respectively. The difference in smoking years was also true for current smokers, but the smoking years were for both sexes 10 years higher on average. Furthermore, outcome differences of former smoking could be caused by differences in nicotine inhalation. Males smoked more cigarettes per day and other (usually stronger) blends than females (Haustein 2001). Our results also showed that current/former smoking is related among western German females to the onset of diseases of the circulatory system and respiratory diseases. That we could not find any impact of smoking on general health and disease transitions among men was probably due to the higher rates of lost smokers at follow-up. Therefore, re-interviewed respondents were selected not only because of mortality but also because of attrition. The influence of reproduction history could not be found for females in which contradicts other studies (Grundy \& Tomassini 2005; Spence \& Eberstein 2009). However, a significant protective effect against mortality was found for later fatherhood of two children in western Germany. Other fatherhood constellations were not statistically significantly, but they tended to lower mortality risk. In contrast to the biological explanation for the influence of female reproduction on mortality (Friedlander 1996), we assumed a cumulative positive effect of family relationship and social support (Ross \& Mirowsky 2002). A further effect is selection. Only a small proportion of western German males (15 per cent) had no children whereas 20 
per cent were not married and lived alone. The impact of migration background is difficult to assess. The variable included the information whether the respondents had ever migrated in their life and how long they lived at the current residence. Details about age at migration, reasons or distance were not included in the data but were identified as risk factors for health in other studies (Hull 1979; Evans 1987; Larson, Bell \& Young 2004). Therefore, the relations found between migration background and health indicators need further research with more detailed data.

\section{Conclusion}

From our analysis three main conclusions can be drawn:

(i) Our first conclusion is of technical nature. The analysis of the transition of the health status for eastern and western German women and men from longitudinal data reveals basically the same risk factors than those found in cross-sectional studies. Especially the influence of socioeconomic differences on morbidity is consistent with recent cross-sectional analysis for Germany. This is an important finding when it comes to identify typical risk factors for other populations. Nevertheless, the broad variety of specific diseases in the LES enabled us to extend the set of diseases associated with socioeconomic factors.

(ii) The analysis for western Germany showed that an increased risk of dying was associated with behavioural determinants among males and with socioeconomic factors among females. The transition into a bad general health status and the onset of specific diseases revealed the reverse picture. Among men, socioeconomic factors were the main drivers for a higher likelihood of the onset of diseases and for deteriorating general health. In contrast, among women the risk of onset of diseases was mainly associated with behavioural factors. In this context it is important to note that lately an adjustment of health behaviours can be observed among women and men, and we can expect that this process will continue in the near future. The percentage of deaths attributable to smoking has stagnated among males since the 1970s on a level of around 22 per cent but it increased continuously among females from 1.2 percent in 1970 to 5.4 per cent in the year 2000 (Peto et al. 2006). Therefore, we can expect that the mortality and morbidity schedules of females will be affected negatively by their increasing smoking hazard and close the gender gap toward the men. Furthermore, the discrepancies within the education level between women and men will decrease in the future. The proportion of females at university increased since 1960 from 28 per cent to 43 per cent in the year 1994 (Geisler 1996). In line with this trend, the employment rate of females increased as well, which leads to an independent and additional income and pension later in life. However, among the cohorts included in the LES we could not find any signs of a relationship between occupational stress and/or dual burden and later health outcomes among females. With a further adjustment of gender roles and health behaviours we might expect that these effects will substitute the impact of socioeconomic factors that we found in the present study. For eastern Germans we could not find reverse effects of socioeconomic factors on health as 
might be expected from the higher female employment rates among the studied cohorts. However, the results suggest that in eastern European societies psychological well-being quantified by life satisfaction might play a more important role for mortality and morbidity at later old age than other factors, especially for females.

(iii) Finally, our analysis reveals a very strong and overall positive effect of sports activity. For both sexes and in both parts of Germany, sports activity reduced the risk of dying significantly. Considering the fact of different age groups at baseline in the eastern and western German LES samples, this result indicates that physical fitness is a guarantee for a longer and healthier life. According to the findings of other studies we can expect that this effect will further increase in the future. Through an analysis of the German Socioeconomic Panel Becker, Klein and Schneider (2006) found that the proportion of males and females who were active in sports at least once per week increased from 26 per cent in 1992 to 30 per cent in 2001. The percentage of sports inactivity, on the other hand, declined from 51 to 45 per cent. Although the percentage of physical activity is lower among eastern Germans they exhibit a higher rate of increase than their western German counterparts (see Luy 2005). Thus, it is likely that the future elderly will profit from their increased sports activity. This holds likewise for both parts of Germany and for both sexes. 


\section{References}

Abramson, J.L., Williams, S.A., Krumholz, H.M. \& Vaccarino, V. 2001, 'Moderate alcohol consumption and risk of heart failure among older persons', Journal of the American Medical Association, vol. 285, no. 15, pp. 1971-1977.

Akker, M.v.d., Buntinx, F. \& Knottnerus, J.A. 1996, 'Comorbidity or multimorbidity: What's in a name. A review of literature', European Journal of General Practice, vol. 2, no. 2, pp. $65-70$.

Akker, M.v.d.,Buntinx, F., Metsemakers, J.F., Roos, S. \& Knottnerus, J.A. 1998, 'Multimorbidity in general practice: Prevalence, incidence, and determinants of co-occurring chronic and recurrent diseases', Journal of Clinical Epidemiology, vol. 51, no. 5, pp. 367-375.

Bartley, M. 1991, 'Health and labour force participation: Stress, selection, and the reproduction costs of labour power', Journal of Social Policy, vol. 20, no. 3, pp. 327-364.

Bartley, M. 1994, 'Unemployment and ill health: Understanding the relationship', Journal of Epidemiology and Community Health, vol. 48, no. 4, pp. 333-337.

Becker, S., Klein, T. \& Schneider, S. 2006, 'Sportaktivität in Deutschland im 10-JahresVergleich: Veränderungen und soziale Unterschiede', Deutsche Zeitschrift für Sportmedizin, vol. 57 , no. 9 , 226-232.

Beresford, T.P. \& Katsoyannis, K.K. (eds.) 1995, Alcohol and aging, Oxford University Press, New York.

Berkman, C.S. \& Gurland, B.J. 1998, 'The relationship among income, other socioeconomic indicators, and functional level in older people', Journal of Aging and Health, vol. 10, no. 1, pp. 81- 98 .

Berkman, L.F. \& Glass, T. 2000, 'Social Integration, social networks, social support and health' in: Social epidemiology, eds. L.F. Berkman and I. Kawachi, Oxford University Press, New York, pp. 137-173.

Blane, D. 2006, 'The life course, the social gradient, and health' in Social Determinants of Health, eds. M. Marmot, and R.G. Wilkinson, R.G., Oxford University Press, Oxford \& New York, pp. 54-77.

Blaxter, M. 1990, Health and lifestyle, Routledge, London \& New York.

Brody, J.A. \& Schneider, E.L. 1986, 'Diseases and disorders of aging: A hypothesis', Journal of Chronic Diseases, vol. 39, pp. 871-876. 
Calverley, P. \& Pride, N. (eds.) 1995, Chronic obstructive pulmonary diseases, Chapman and Hall, London.

Cavelaars, A.E., Kunst, A.E., Geurts, J.J., Crialesi, R., Grötvedt, L., Helmert, U., Lahelma, E., Lundberg, O., Matheson, J., Mielck, A., Rasmussen, N.K., Regidor, E., do Rosário-Giraldes, M., Spuhler, T. \& Mackenbach, J.P. 2000, 'Educational differences in smoking: international comparison', British Medical Journal, vol. 320, no. 7242, pp. 1102-1107.

Christensen, K., Johnson, T.E. \& Vaupel, J.W. 2006, 'The quest for genetic determinants of human longevity: Challenges and insights', Nature Review Genetics, vol. 7, no. 6, pp. 436-448.

Corrao, G., Bagnardi, V.,Zambon, A. \& Torchio, P. 1998, 'A meta-analysis of alcohol intake in relation to risk of liver cirrhosis', Alcohol and Alcoholism, vol. 33, no. 4, pp. 381-392.

David, J.L. \& Kaplan, H.B. 1995, ‘Gender, social roles and health care utilization', Applied Behavioral Science Review, vol. 3, no. 1, pp. 39-64.

Doblhammer, G. 2000, 'Reproductive history and mortality later in life: A comparative study of England and Wales and Austria', Population Studies, vol. 54, no. 2, pp. 169-176.

Doll, R, Peto, R., Boreham, J. \& Sutherland, I. 2004, 'Mortality in relation to smoking: 50 years' observations on male British doctors', British Medical Journal, vol. 328, no. 7455, pp. 1519-1533.

Evans, J. 1987, 'Introduction: Migration and health', International Migration Review, Special Issue: Migration and Health, vol. 21, no. 3, pp. V-XIV.

Feinstein, J.S. 1993, 'The relationship between socioeconomic status and health: A review of the literature', The Milbank Quarterly, vol. 71, no. 2, pp. 279-322.

Friedlander, N.J. 1996, 'The relation of lifetime reproduction to survivorship in women and men: A prospective study', American Journal of Human Biology, vol. 8, no. 6, pp. 771-783.

Gärtner, K. 2001, Lebensstile und ihr Einfluss auf Gesundheit und Lebenserwartung - Der Lebenserwartungssurvey des BIB, Projekt- und Materialdokumentation. Bundesinstitut für Bevölkerungsforschung, Wiesbaden.

Geisler, R. 1996, Die Sozialstruktur Deutschlands, Westdeutscher Verlag, Opladen.

Gjonça A., Brockmann H. \& Maier H. 2000, 'Old-age mortality in Germany prior to and after Reunification', Demographic Research, vol. 3, article 1. 
Gorman, B.K. \& Sivaganesan, A. 2007, 'The role of social support and integration for understanding socioeconomic disparities in self-rated health and hypertension', Social Science and Medicine, vol. 65, no. 5, pp. 958-975.

Graham, H. 2002, 'Building an inter-disciplinary science of health inequalities: The example of lifecourse research', Social Science and Medicine, vol. 55, no. 11, pp. 2005-2016.

Green, A., Beral, V. \& Moser, K. 1988, 'Mortality in women in relation to their childbearing history’, British Medical Journal, vol. 297, no. 6645, pp. 391-395.

Gruer, L., Hart, C.L., Gordon, D.S. \& Watt, G.C. 2009, 'Effect of tobacco smoking on survival of men and women by social position: a 28 year cohort study', British Medical Journal, vol. 338:b480.

Grundy, E. \& Holt, G. 2000, 'Adult life experiences and health in early old age in Great Britain', Social Science and Medicine, vol. 51, no. 7, pp. 1061-1074.

Grundy, E \& Tomassini, C. 2005, 'Fertility history and health in later life: A record linkage study in England and Wales', Social Science and Medicine, vol. 61, no. 1, pp. 217-228.

Guimarães, R.M. 2007, 'Health capital, life course and ageing', Gerontology, vol. 53, no. 2, pp. 96-101.

Hach, I., Ruhl, U.E., Klose, M., Klotsche, J., Kirch, W. \& Jacobi, F. 2007, 'Obesity and the risk for mental disorders in a representative German adult sample', European Journal of Public Health, vol. 17, no. 3, pp. 297-305.

Haustein, K.O. 2001, Tabakabhängigkeit.Gesundheitliche Schäden durch das Rauchen.Ursachen-Folgen-Behandlungsmöglichkeiten-Konsequenzen für Politik und Gesellschaft, Deutscher Ärzte-Verlag, Köln.

Heinemann, L., Dinkel, R. \& Görtler, E. 1996, 'Life expectancy in Germany: Possible reasons for the increasing gap between East and West Germany', Reviews on Environmental Health, vol. 11 , no. 1-2, pp. 15-26.

Helmert, U., Borgers, D. \& Bamman, K. 2001, 'Soziale Determinanten des Rauchverhaltens in Deutschland: Ergebnisse des Mikrozensus 1995', Sozial- und Präventivmedizin, vol. 46, no. 3, pp. 172-181.

Helmert, U., Herman, B., Joeckel, K.H., Greiser, E. \& Madans, J. 1989, 'Social class and risk factors for coronary heart disease in the Federal Republic of Germany. Results of the baseline survey of the German Cardiovascular Prevention Study (GCP)', Journal of Epidemiology and Community Health, vol. 43, no. 1, pp. 37-42. 
Helmert, U., Mielck, A. \& Shea, S. 1997, 'Poverty and health in West Germany', Sozial- und Präventivmedizin, vol. 42, no. 5, 276-285.

Hoffmann, D. \& Schwartz, M. (eds.) 2005, Sozialstaatlichkeit in der DDR. Sozialpolitische Entwicklungen im Spannungsfeld von Diktatur und Gesellschaft 1945/49-1989, Oldenbourg Wissenschaftsverlag, München.

Hosmer, D.W. \& Lemeshow, S. 2000, Applied logistic regression, John Wiley and Sons Inc., New York.

House, J.S., Kessler, R.C. \& Herzog, A.R. 1990, ‘Age, socioeconomic status, and health', The Milbank Quarterly, vol. 68, no. 3, pp. 383-411.

House, J.S., Lepkowski, J.M., Kinney, A.M., Mero, R.P., Kessler, R.C. \& Herzog, A.R.1994, 'The social stratification of aging and health', Journal of Health and Social Behavior, vol. 35, no. 3, pp. 213-234.

Hull, D. 1979, 'Migration, adaptation, and illness: A review', Social Science and Medicine, vol. $13 \mathrm{~A}$, no. 1 , pp. 25-36.

Jenkins, C.D. 1976, 'Recent evidence supporting psychologic and social risk factors for coronary disease', The New England Journal of Medicine, vol. 294, no. 19, pp. 1033-38.

Kaplan, G.A. \& Keil, J.E. 1993, 'Socioeconomic factors and cardiovascular disease: A review of the literature', Circulation, vol. 88, no. 4, pp. 1973-1998.

Kaplan, M.S., Huguet, N., Newsom, J.T., McFarland, B.H. \& Lindsay, J. 2003, 'Prevalence and correlates of overweight and obesity among older adults: Findings from the Canadian National Population Health Survey', Journal of Gerontology: Medical Sciences, vol. 58A, no. 11, pp. 1018-1030.

Klein, T. 1996, 'Mortalität in Deutschland - Aktuelle Entwicklungen und soziale Unterschiede' in Lebenslagen im Wandel: Sozialberichterstattung im Längsschnitt, eds W. Zapf, J. Schupp \& R. Habich, Campus-Verlag, Frankfurt, pp 366-377.

Knesebeck, O.v.d. 1998, Subjektive Gesundheit im Alter. Soziale, psychische und somantische Einflüsse, Lit Verlag, Münster.

Knesebeck, O.v.d., Lüschen, G., Cockerham, W.C. \& Siegrist, J. 2003, 'Socioeconomic status and health among the aged in the United States and Germany: A comparative cross-sectional study', Social Science and Medicine, vol. 57, no. 9, pp. 1643-1652. 
Knesebeck, O.v.d. \& Schäfer, I. 2006, 'Gesundheitliche Ungleichheit im höheren Lebensalter' in Gesundheitliche Ungleichheit - Grundlagen, Probleme, Konzepte, eds. M. Richter. and K. Hurrelmann, VS Verlag für Sozialwissenschaften, Wiesbaden, pp. 253-265.

Kuh, D. \& Ben-Shlomo, Y. 2004, Life course approach to chronic disease epidemiology, 2nd edn. Oxford University Press, Oxford and New York.

Kuh, D., Ben-Shlomo, Y., Lynch, J., Hallqvist, J. \& Power, C. 2003, 'Life course epidemiology', Journal of Epidemiology and Community Health, vol. 57, no. 10, pp. 778-783.

Kunzendorff, E. 1994, 'Soziale Differenzierung in epidemiologischen und medizinsoziologischen Untersuchungen auf dem Gebiet der DDR. Gab es soziale Ungleichheit als medizinisch relevantes Problem?' in Krankheit und soziale Ungleichheit. Sozialepidemiologische Forschung in Deutschland, ed. A. Mielck, Leske+Budrich, Opladen, pp. 53-92.

Lampert, T. \& Kroll, L.E. 2006, 'Einkommensdifferenzen in der Gesundheit und Lebenserwartung - Quer- und Längsschnittbefunde des Sozio-oekonomischen Panels (SOEP)', Gesundheitswesen, vol. 68, no 4., pp. 219-230.

Larson, A., Bell, M. \& Young, A.F. 2004, 'Clarifying the relationships between health and residential mobility’, Social Science and Medicine, vol. 59, no. 10, pp. 2149-2160.

Leserman J., Li Z., Hu, Y.J. \& Drossman, D.A. 1998, 'How multiple types of stressors impact on health', Psychosomatic Medicine, vol. 60, no. 2, pp. 175-181.

Lillard, L.A. \& Panis, C.W. 1996, 'Marital status and mortality: The role of health', Demography, vol. 33, no. 3, pp. 313-327.

Lin, C.C., Rogot, E., Johnson, N.J., Sorlie, P.D. \& Arias, E. 2003, 'A further study of life expectancy by socioeconomic factors in the National Longitudinal Mortality Study', Ethnicity and Disease, vol. 13, no 2., pp. 240-247.

Lindsted, K.D., Tonstad, S. \& Kuzma, J.W. 1991, 'Self-report of physical activity and patterns of mortality in seventh-day Adventist men', Journal of Clinical Epidemiology, vol. 44, no. 45, pp. 355-64.

Lund, E., Arnesen, E. \& Borgan, JK. 1990, 'Pattern of childbearing and mortality in married women - a national prospective study from Norway', Journal of Epidemiology and Community Health, vol. 44, no. 3, pp. 237-270.

Lüschen, G., Geling, O., Janssen, C., Kunz, G. \& Knesebeck, v.d.O. 1997a, 'After unification: Gender and subjective health status in East and West Germany', Social Science and Medicine, vol. 44, no. 9, pp. 1313-1323. 
Lüschen, G., Niemann, S. \& Apelt, P. 1997b, 'The integration of two health systems: Soical stratification, work and health in East and West Germany', Social Science and Medicine, vol. 44, no. 6, pp. 883-899.

Luy, M. 2004, 'Verschiedene Aspekte der Sterblichkeitsentwicklung in Deutschland von 1950 bis 2000', Zeitschrift für Bevölkerungswissenschaft, vol. 29, no. 1, pp. 3-62.

Luy, M. 2005, 'West-Ost-Unterschiede in der Sterblichkeit unter besonderer Berücksichtigung des Einflusses von Lebensstil und Lebensqualität'. in: Lebensstile, Lebensphasen, Lebensqualität. Interdisziplinäre Analysen von Gesundheit und Sterblichkeit aus dem Lebenserwartungssurvey des BIB, eds. K. Gärtner, E. Grünheid \& M. Luy, VS Verlag für Sozialwissenschaften, Wiesbaden, pp. 333-364.

Luy, M. \& Di Giulio, P. 2005, 'Der Einfluss von Verhaltensweisen und Lebensstilen auf die Mortalitätsdifferenzen der Geschlechter' in: Lebensstile, Lebensphasen, Lebensqualität. Interdisziplinäre Analysen von Gesundheit und Sterblichkeit aus dem Lebenserwartungssurvey des BIB, eds. K. Gärtner, E. Grünheid \& M. Luy, VS Verlag für Sozialwissenschaften, Wiesbaden, pp. 365-392.

Maddox, G.L. \& Douglass, E.B. 1973, 'Self-assessment of health: A longitudinal study of elderly subjects', Journal of Health and Social Behavior, vol. 14, no. 1, pp. 87-93.

Mäkelä, P., Valkonen, T. \& Martelin, T. 1997, 'Contribution of deaths related to alcohol use to socioeconomic variation in mortality: Register based follow up study', British Medical Journal, vol. 315, no. 7102, pp. 211-216.

Manderbacka, K. 1998, 'Examining what self-rated health question is understood to mean by respondents', Scandinavian Journal of Public Health, vol. 26, no. 2, pp. 145-153.

Marmot, M. \& Wilkinson, R.G. (eds.) 2006, Social determinants of health, 2nd edn, Oxford University Press, Oxford \& New York.

Mayer, K.U. \& Wagner, M. 1996, 'Lebenslagen und soziale Ungleichheit im hohen Alter' in Die Berliner Altersstudie, eds. K.U. Mayer and P.B. Baltes,. Akademie Verlag, Berlin, pp. 251-275.

Melzer, D., McWilliams, B., Brayne, C., Johnson, T. \& Bond, J. 2000, 'Socioeconomic status and the expectation of disability in old age: Estimates for England', Journal of Epidemiology and Community Health, vol. 54, no. 4, pp. 286-292.

Mielck, A. (ed.) 1994, Krankheit und soziale Ungleichheit. Sozialepidemiologische Forschung in Deutschland, Leske+Budrich, Opladen. 
Mielck, A., Cavelaars, A., Helmert, U., Martin, K., Winkelhake, O. \& Kunst, A.E. 2000, 'Comparison of health inequalities between East and West Germany', European Journal of Public Health, vol. 10, no. 4, pp. 262-267.

Mollenkopf, H. \& Walker, A. (eds.) 2007, Quality of life in old age - International and multidisciplinary perspective, Springer, Dordrecht.

Mossey, J.M. \& Shapiro, E. 1982, 'Self-rated health', American Journal of Public Health, vol. 72 , pp. 800-808.

Mukamal, K.J., Ascherio, A., Mittleman, M.A., Conigrave, K.M., Camargo, C.A. Jr., Kawachi, I., Stampfer, M.J., Willett, W.C. \& Rimm, E.B. 2005, 'Alcohol and risk for ischemic stroke in men: The role of drinking patterns and usual beverage', Annals of Internal Medicine, vol. 142, no. 1, pp. 11-19.

Mustard, C.A., Kaufert, P., Kozyrskyj, A. \& Mayer, T. 1998, 'Sex differences in the use of health care services', The New England Journal of Medicine, vol. 338, no. 23, pp. 1678-1683.

Nolte, E., Shkolinikov, V. \& McKee, M. 2000, 'Changing mortality patterns in East and West Germany and Poland. I: Long term trends (1960-1997)', Journal of Epidemiology and Community Health, vol. 54, pp. 890-898.

OECD 1999, Classifying educational programmes. Manual for ISCED-97. Implementation in OECD Countries, Organisation for Economic Co-Operation and Development, Washington.

Paffenbarger, R.S. Jr., Hyde R.T., Wing A.L., Lee I.M., Jung D.L. \& Kampert J.B. 1993, ‘The association of changes in physical-activity level and other lifestyle characteristics with mortality among men', The New England Journal of Medicine, vol. 328, no. 8, pp. 538-545.

Peto, R., Lopez, A.D., Boreham, J. \& Thun, M. 2006, 'Mortality from Smoking in Developed Countries 1950-2000', 2nd edn., CTSU Oxford, Available at http://www.ctsu.ox.ac.uk/ tobacco/index.htm

Rathmann, W., Haastert, B., Icks, A., Giani, G., Holle, R., Meisinger, C. \& Mielck, A. 2005, 'Sex differences in the associations of socioeconomic status with undiagnosed diabetes mellitus and impaired glucose tolerance in the elderly population: The KORA survey 2000', European Journal of Public Health, vol. 15, no. 6, pp. 627-633.

Ross, C.E. \& Mirowsky, J. 2002, 'Family relationships, social support and subjective life expectancy', Journal of Health and Social Behavior, vol. 43, no. 4, pp. 469-489.

Sacco, R., Elkind, M., Boden-Albala, B., Lin, I.F., Kargman, D.E., Hauser, W.A., Shea, S. \& Paik, M.C. 1999, 'The protective effect of moderate alcohol consumption on ischemic stroke', Journal of the American Medical Association, vol. 281, no. 1, pp. 53-60. 
Sandvik, L., Erikssen, J., Thaulow, E., Eriksson, G., Mundal, R. \& Rodahl, K. 1993, 'Physical fitness as a predictor of mortality among healthy, middle-aged Norwegian men', The New England Journal of Medicine, vol. 328, no. 8, pp. 533-537.

Scafato, E., Galluzzo, L., Gandin, C., Ghirini, S., Baldereschi, M., Capurso, A., Maggi, S. \& Farchi, G. 2008, 'Marital and cohabitation status as predictor of mortality: A 10-year followup of an Italian elderly cohort', Social Science and Medicine, vol. 67, no. 9, pp. 1456-1464.

Simon, J.G., De Boer, J.B., Joung, I.M., Bosma, H. \& Mackenbach, J.P. 2005, 'How is your health in general? A qualitative study on self-assessed health', European Journal of Public Health, vol. 15, no. 2, pp. 200-208.

Spence, N.J. \& Eberstein, I.W. 2009, 'Age at first birth, parity, and post-reproductive mortality among white and black women in the US, 1982-2002', Social Science and Medicine, vol. 68 , no. 9 , pp. 1625-1632.

Statistisches Bundesamt. 2007a, Todesursachen in Deutschland. Gestorbene in Deutschland an ausgewählten Todesursachen, Statistisches Bundesamt, Wiesbaden.

Statistisches Bundesamt. 2007b, Diagnosedaten der Patienten und Patientinnen in Krankenhäusern (einschl. Sterbe- und Stundenfälle), Statistisches Bundesamt, Wiesbaden.

Steinhagen-Thiessen, E. \& Borchelt, M. 1996, 'Morbidität, Medikation und Funktionalität im Alter' in Die Berliner Altersstudie, eds. K.U. Mayer \& P.B. Baltes,. Akademie Verlag, Berlin, pp. 151-183.

Sulander, T.T. \& Uutela, A.K. 2007, 'Obesity and education: Recent trends and disparities among 65- to 84-year-old men and women in Finland', Preventive Medicine, vol. 45, no.2-3, pp.153-156.

Sundquist, K., Qvist, J., Johansson, S.E. \& Sundquist, J. 2004, 'Increasing trends of obesity in Sweden between 1996/97 and 2000/01', International Journal of Obesity, vol. 28, no. 2, pp. 254-261.

Thun, M.J., Peto, R., Lopez, A.D., Monaco, J.H., Henley, S.J., Heath, C.W. Jr. \& Doll, R. 1997, 'Alcohol consumption and mortality among middle-aged and elderly U.S. adults', The New England Journal of Medicine, vol. 337, no. 24, pp. 1705-1714.

U.S. Department of Health and Human Services (USDHHS) 1996, Physical activity and health: A report of the Surgeon General, U.S. Department of Health and Human Services, Centers for Disease Control and Prevention, National Center for Chronic Disease Prevention and Health Promotion, Atlanta, Georgia. 
US Department of Health and Human Services (USDHHS) 2004, The health consequences of smoking: A report of the Surgeon General, US Department of Health and Human Services, Centers for Disease Control and Prevention, National Center for Chronic Disease Prevention and Health Promotion, Office on Smoking and Health, Atlanta, Georgia.

Vaupel, J.W., Carey J.R., Christensen K., Johnson T.E., Yashin A.I., Holm N.V., Iachine I.A., Kannisto V., Khazaeli A.A., Liedo P., Longo V.D., Zeng Y., Manton K.G. \& Curtsinger J.W.1998, 'Biodemographic trajectories of longevity'. Science, vol. 280, no. 5365, pp. 855-860.

Vaupel, J.W., Carey, J.R.\& Christensen, K. 2003, 'Aging. It's never too late', Science, vol. 301, no. 5640, pp. 1679-1681.

Wadsworth, M.E. 1997, 'Health inequalities in the life course perspective', Social Science and Medicine, vol. 44, no. 6, pp. 859-869.

Waldron, I., Hughes, M.E. \& Brooks, T.L. 1996, 'Marriage protection and marriage selection prospective evidence for reciprocal effects of marital status and health', Social Science and Medicine, vol. 43, no. 1, pp. 113-123.

Wilkinson, R.G. 2001, Kranke Gesellschaften. Soziales Gleichgewicht und Gesundheit, Springer Verlag, Wien.

Wyke, S. \& Ford, G. 1992, 'Competing explanations for associations between marital status and health', Social Science and Medicine, vol. 34, no. 5, pp. 523-532. 


\section{Appendix: Classification of diseases based on ICD-9}

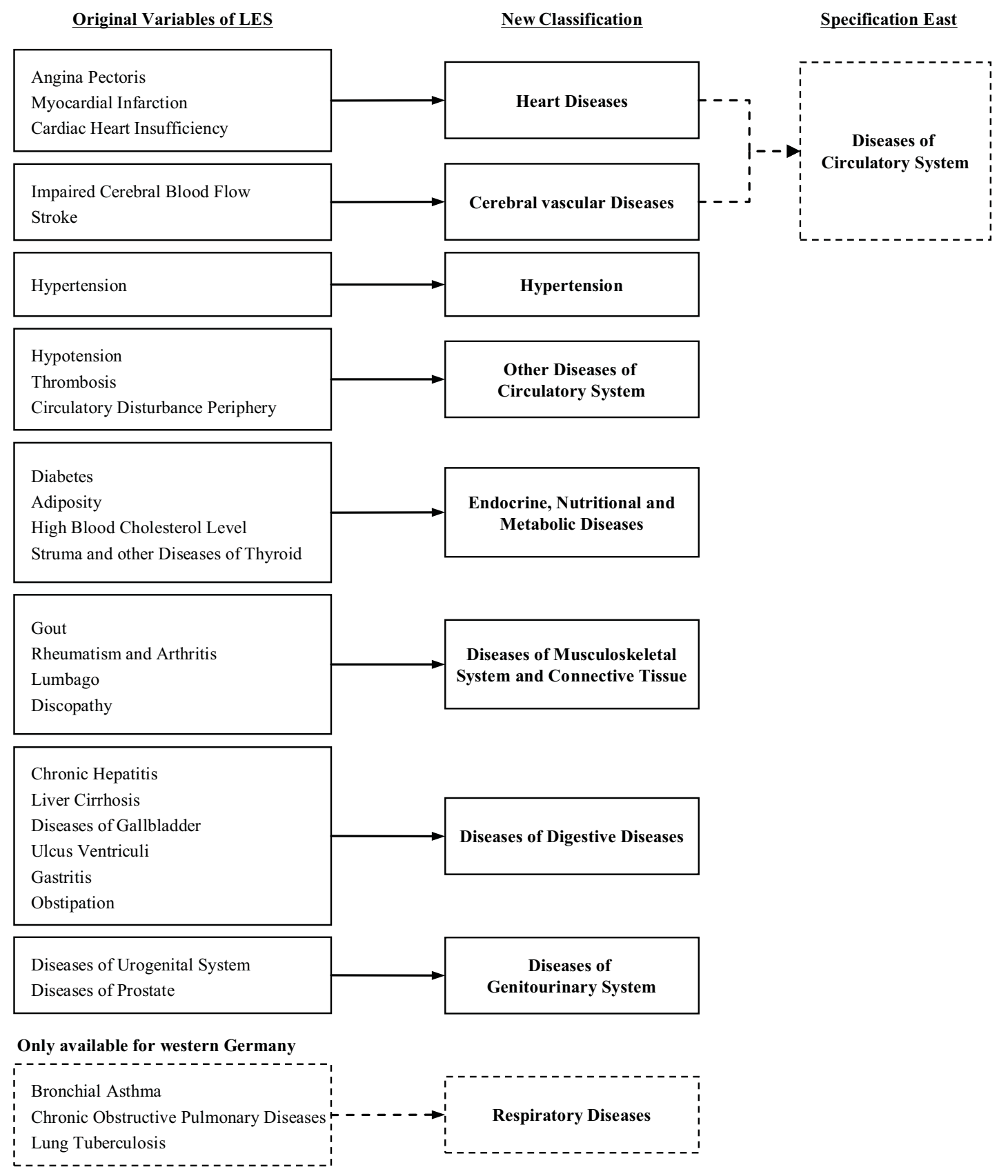




\section{VIENNA INSTITUTE OF DEMOGRAPHY}

\section{Working Papers}

Wrzaczek, Stefan, Michael Kuhn, Alexia Prskawetz, and Gustav Feichtinger, The Reproductive Value in Distributed Optimal Control Models, VID Working Paper 04/2009.

Wendland, Maike und Isabella Buber, Ein Vergleich der Ergebnisse der ersten Welle des Österreichischen,, Survey of Health, Ageing and Retirement in Europe" (SHARE) und der „Österreichischen Gesundheitsbefragung“ (ATHIS), VID Working Paper 03/2009.

Thomson, Elizabeth, Maria Winkler-Dworak, Martin Spielauer, and Alexia Prskawetz, Union Instability as an Engine of Fertility, VID Working Paper 02/2009.

Grafeneder-Weissteiner, Theresa and Klaus Prettner, Agglomeration and population ageing in a two region model of exogenous growth, VID Working Paper 01/2009.

Skirbekk, Vegard, Anne Goujon, and Eric Kaufmann, Secularism or Catholicism? The Religious Composition of the United States to 2043, VID Working Paper $04 / 2008$.

Ediev, Dalkhat M., Extrapolative Projections of Mortality: Towards a More Consistent Method, VID Working Paper 03/2008.

Schwarz, Franz, Christian Korbel, and Johannes Klotz, Alcohol-Related Mortality among Men in Austria 1981-2002 and the Importance of Qualification and Employment, VID Working Paper 02/2008.

Buber, Isabella and Henriette Engelhardt, The Relation Between Depressive Symptoms and Age Among Older Europeans. Findings from SHARE, VID Working Paper 01/2008.

Aparicio Diaz, Belinda, Thomas Fent, Alexia Prskawetz, and Laura Bernardi, Transition to Parenthood: The role of Social Interaction and Endogenous Networks, VID Working Paper 05/2007.

Ediev, Dalkhat M, On Projecting the Distribution of Private Households by Size, VID Working Paper 04/2007.

Biehl, Kai and Thomas Fent, Vorausschätzungen für die Entwicklung der Gesamtbevölkerung und der Beschäftigung in Österreich bis 2035, VID Working Paper 03/2007

The Vienna Institute of Demography Working Paper Series receives only limited review. Views or opinions expressed herein are entirely those of the authors. 